Linköping Studies in Science and Technology

Licentiate Thesis No. 1863

\title{
Efficiency of heat and work in a regional energy system
}

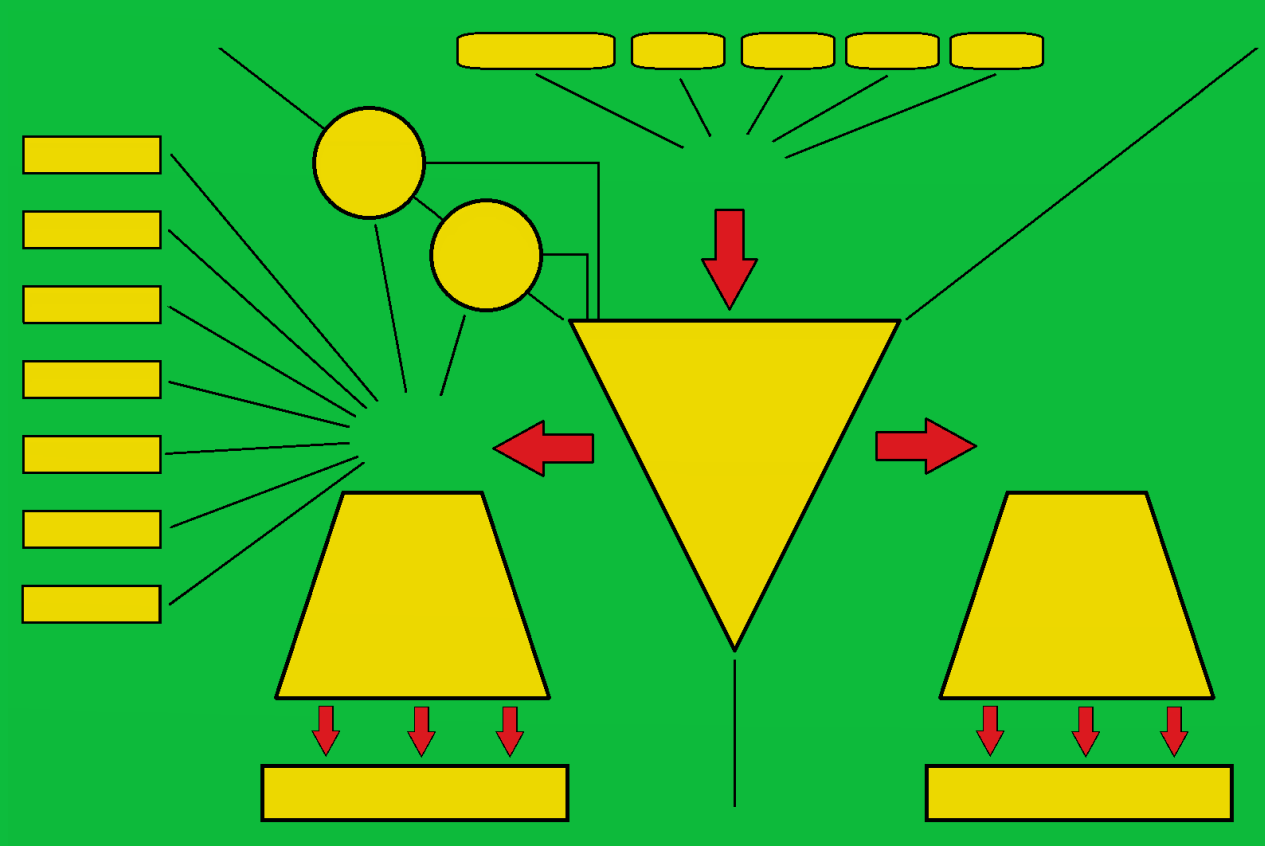

\section{Tommy Rosén}



Linköping studies in science and technology

Licentiate Thesis No. 1863

\title{
Efficiency of heat and work in a regional energy system
}

\author{
Tommy Rosén
}

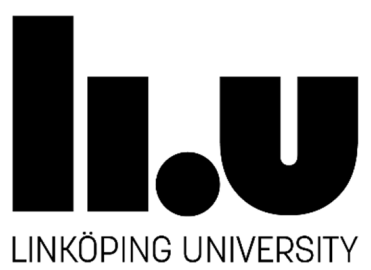

Division of Energy Systems

Department of Management and Engineering

Linköping University, Sweden

Linköping 2019 
Efficiency of heat and work in a regional energy system

(CTommy Rosén, 2019

Cover design and idea by Tommy Rosén

Cover illustration work by Tommy Rosén and Per Lagman, LiU-Tryck, Linköping Sweden

Published article has been reprinted with the permission of the copyright holder.

Printed in Sweden by LiU-Tryck, Linköping, Sweden, 2019

ISBN: 978-91-7929-934-7

ISSN: 0280-7971 


\begin{abstract}
One of the largest flows of energy in Swedish municipalities is the fuel-energy flow through the regional combined heat and power (CHP) plant. The customer products from this flow are mainly electricity to the electricity grid and heat to the building sector. There are many ways to describe and examine this fuel-energy flow, and there are many perspectives. This thesis presents one perspective. It is a top-down, analytical and numerical perspective on the efficiency of heat and work in a regional energy system. The analysis focus on the present situation in Linköping municipality and aims at describing the energy efficiency improvement potential. Three subsystems are considered, the regional production of electricity, the regional production of heat, and the regional public transport by bus. These three systems are physically all heat engines i.e. engines that derive work and/or heat from fuel combustion processes. It is important to notice that the analysis in this thesis does not describe the theoretical improvement potential, that potential is considerably higher than the implementable potential, but of no practical use. Instead the analysis is as far as possible based on real world measured efficiencies and efficiency values of best practice (Best available technology).
\end{abstract}

The analysis shows that hardware investments at the CHP plant can improve the electricity generation efficiency and thereby reduce $\mathrm{CO}_{2}$ emissions. The investments are in high pressure turbines, medium pressure turbines and preheaters. The size of the improvement is hard to quantify because it depends partly on unknown factors in the surrounding electricity market. In the studied system $\mathrm{CO}_{2}$ reduction could be as high as $40-60 \%$.

The regionally produced biogas would be used more efficiently if it were used in the local combined cycle gas turbine instead of being used in internal combustion engines in buses. The buses would instead be electrically driven. This use of biogas would create a better integrated fuel-energy flow and reduce heat losses.

Another improvement is to reduce the system temperatures in the district heating system. The study shows that the efficiency gains, because of lower system temperatures, would increase electricity production by about $1-3 \%$, and that greenhouse gas emissions would be reduced by $4-20 \%$. However, these improvements are dependent on demand side investments in the district heating system and are therefore slow to implement. 



\section{Sammanfattning}

Ett av de största energiflödena i svenska kommuner är bränsle/energi-flödet genom det regionala kraftvärmeverket. De konsumentprodukter som detta energiflöde producerar är främst uppvärmning av bostäder och elkraft. Det finns många sätt att beskriva och utvärdera detta bränsle/energi-flöde och det finns många olika perspektiv. Det här arbetet analyserar energiflödet med en analytisk "top-down" metod. Analysen utgår ifrån den nuvarande situationen i Linköpings kommun och avser att belysa den förbättringspotential som finns med avseende på systemets verkningsgrad. Tre delsystem har studerats, det regionala systemet för värmeproduktion, det regionala systemet för elproduktion och det regionala kollektivtrafiksystemet för innerstadstrafik med buss. Dessa tre system är fysikaliskt värmemotorer d.v.s. de är system som nyttjar termisk energi från förbränningsprocesser för att utföra ett arbete och/eller generera värme. Det är viktigt att notera att analyserna i detta arbete inte avser att beskriva en teoretisk förbättringspotential. Analyserna avser istället att belysa den praktiska, implementerbara, förbättringspotentialen. Därför har arbetet så långt som möjligt utgått ifrån uppmätta data och numeriska värden på verkningsgrader ifrån redan existerande anläggningar eller tekniska komponenter.

Analyserna visar att hårdvaruinvesteringar i det lokala kraftvärmeverket skulle öka elproduktionen och därigenom sänka koldioxidutsläppen. De investeringar som skulle behöva göras är investeringar i högtrycksturbiner, mellantrycksturbiner och förvärmare. De sänkta koldioxidutsläppen är svåra att kvantifiera eftersom de delvis beror på okända faktorer på den omgivande elmarknaden. Reduktionen av koldioxidutsläppen skulle kunna vara så stor som $40-60 \%$.

Den lokalt producerade biogasen skulle användas mer effektivt om den användes i den lokala gaskombi-anläggningen istället för att användas som bussbränsle som är det nuvarande användningsområdet för detta bränsle. Bussarna skulle istället kunna ersättas med elbussar. En sådan förändring av biogas-användningen skulle innebära ett bättre integrerat energisystem med lägre värmeförluster.

En annan möjlig förbättring av kraftvärmesystemet är att sänka returtemperaturerna i fjärrvärmesystemet. Analyserna visar att elverkningsgraden skulle förbättras $1-3 \%$ och att koldioxidutsläppen skulle kunna minska med 4-20\%. Dessa förbättringar skulle däremot kräva investeringar på kraftvärmesystemets kundsida och bedöms därför vara långsamma att implementera. 



\section{Acknowledgements}

To begin with, I would like to thank my supervisor Louise Ödlund, who has supported me throughout my research process. I also like to thank my co-supervisor Shahnaz Amiri.

I like to thank Stefan Anderberg for all the help during the writing process of this thesis.

I like to thank Linköping University, and especially all those teachers at the university that have been a part of my Master of Science in Applied Physics and Electrical Engineering education. It is really a good Master of Science education, and I use knowledge from this training period in my life almost every day.

Many thanks to Lina la Fleur and Stefan Blomqvist who have helped me with big and small things, and most importantly been very good colleagues. I also like to thank all other colleagues at the Energy system department.

A special thanks to Link, my old friend, who understands the importance of coffee breaks and card games.

I like to thank my family - my wife Linda, and our three children Julia, Sofie and Anton. You are all amazing. 



\section{List of abbreviations}

\begin{tabular}{ll} 
4GDH & 4th Generation District Heating \\
CCGT & Combined Cycle Gas Turbine \\
CCP & Coal Condensing Power \\
CHP & Combined Heat and Power \\
COP & Coefficient of Performance \\
DH & District Heating \\
DHS & District Heating System \\
EJy & Exajoule per year \\
EV & Electric Vehicle \\
FGC & Flue Gas Condenser \\
GWh & Gigawatt hour \\
HOB & Heat Only Boiler \\
ICE & Internal Combustion Engine \\
kWh & kilowatt hour \\
MODEST & $\begin{array}{l}\text { Model for Optimisation of Dynamic Energy Systems with Time-dependent } \\
\text { components and boundary conditions }\end{array}$ \\
MWh & Megawatt hour \\
RE & Renewable Energy \\
TWh & Terawatt hour \\
& \\
\hline
\end{tabular}





\section{Preface}

We all have a personal background consisting of educational experience, work experience and other personal experience. Through this set of experiences, we try to understand and explain our research findings. My personal background consists of an educational background, with an MSc in Applied Physics and Electrical Engineering, six years' experience of working in the steam turbine industry, and of course all the other big and small events in my life that have influenced the way I perceive things. If I was to choose one thing that has had the greatest influence on this licentiate thesis, it is my experience from working as a process engineer in the steam turbine industry. This experience has given me in-depth knowledge of the electrical efficiency of thermal engines, which is a subject at the core of this thesis. 



\section{Table of contents}

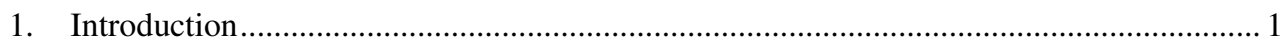

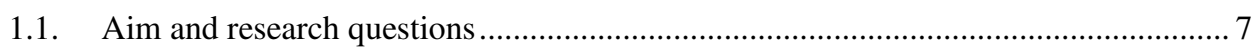

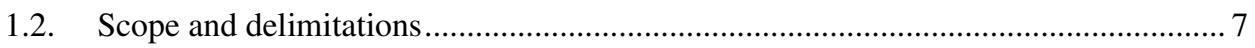

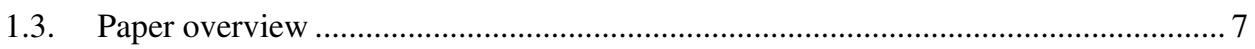

1.4. The research project "Control strategies for district heating" ..................................... 9

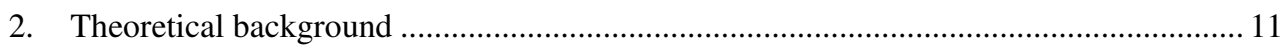

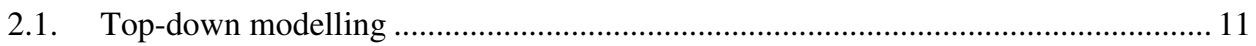

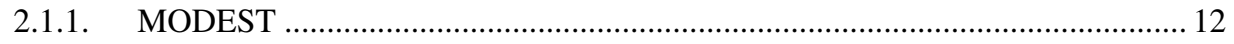

2.2. To measure system performance …………………………………………….... 14

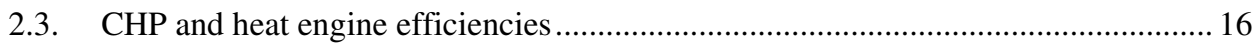

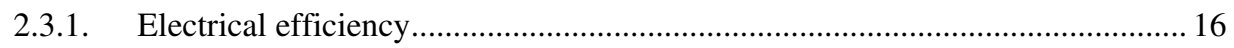

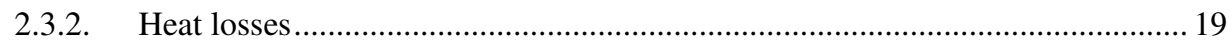

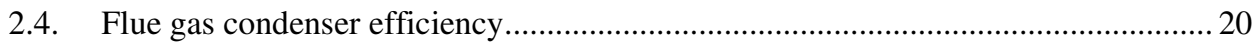

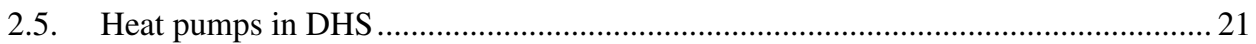

2.6. Three connected markets ................................................................................... 22

2.6.1. The Fuel Market ................................................................................. 22

2.6.2. The Electricity Market in the Nordic region ………………………………..... 23

2.6.3. The Heat Market..................................................................................... 23

2.7. Inclusion of external effects - a system approach .................................................... 24

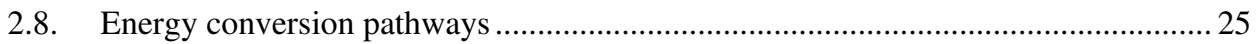

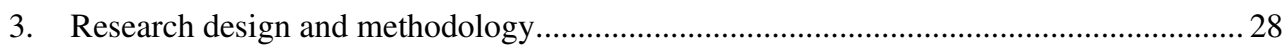

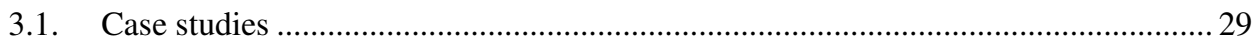

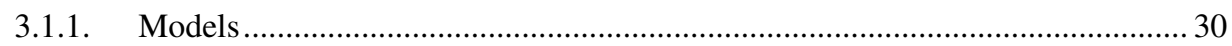

3.1.2. Example of a chain of intensity factors in the model from Paper I..................... 34

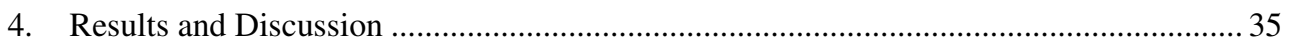

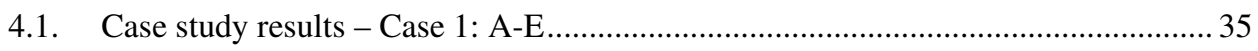

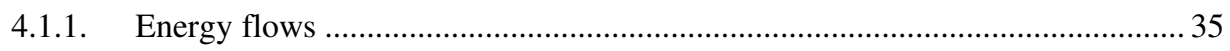




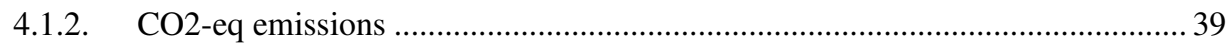

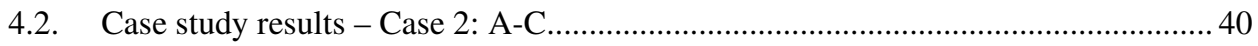

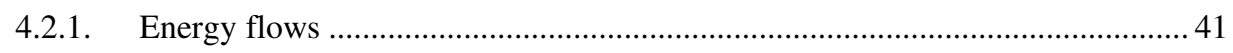

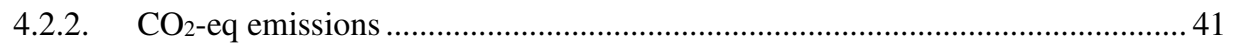

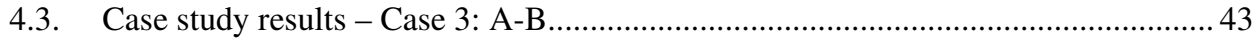

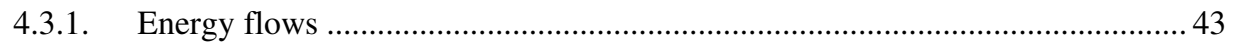

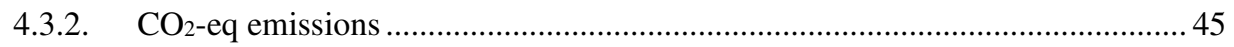

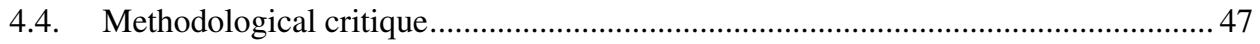

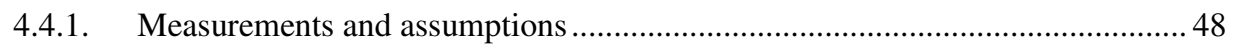

4.4.2. Sensitivity analysis - the relative weight of each assumption ........................... 49

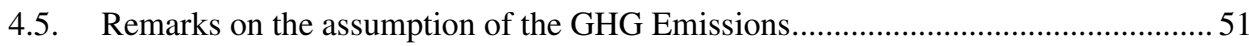

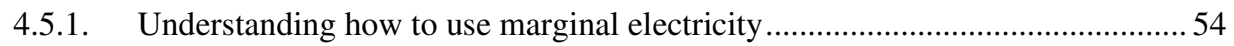

4.6. Using the best conversion pathways - a common interest? ....................................... 55

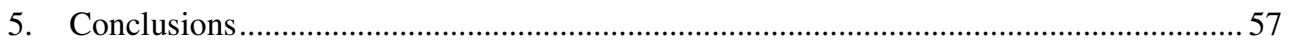

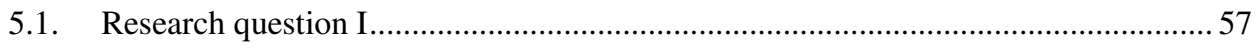

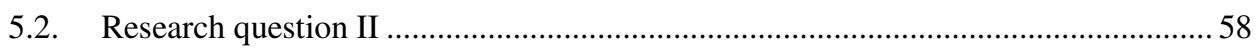




\section{Introduction}

Moriarty et al. [1] examine different scenarios for how global energy use may develop until 2050. They show that to mitigate the problem of greenhouse gas (GHG) emissions, global energy use growth cannot continue. This is because the amount of renewable energy (RE) will not be sufficient to replace the fossil fuels in today's energy balance. Instead of global energy use growth, Moriarty et al. [1] propose that the world will need to manage with far lower levels of energy use than we do today. Achieving this will mean that societies must reexamine their energy use and take measures to reduce energy demanding services and to use energy more efficiently. Other authors draw similar conclusions. Haberl et al. [2] estimate bioenergy potential of $100 \mathrm{EJy}^{-1}$, corresponding to about $18 \%$ of today's global energy use. De Castro et al. [3] estimate solar power potential of 60-120 $\mathrm{EJy}^{-1}$, corresponding to about $11-22 \%$ of today's global energy use. With estimates for hydropower at about $187 \mathrm{EJy}^{-1}$ [4], corresponding to about $33 \%$ of today's global energy use, and with wind power being an intermittent source (although with high energy potential), it is clear that a reduction in energy use and increased efficiency are crucial elements to obtain fossil free global energy use.

Although the $\mathrm{CO}_{2}$ emission problem is a global problem, the practical solutions to obtain increased efficiency and reduced energy use must be implemented in a more local context. Moreover, in a local context it is possible to examine energy efficiencies, energy services and energy losses in a more detailed manner. One of the largest flows of fuel and energy in municipalities in Sweden is the fuel-energy flow through the regional combined heat and power plant. The consumer products that come out of this flow are mainly electricity to the power grid and heat to the residential sector. In Sweden, the energy use in the residential and services sector was $143 \mathrm{TWh}$ in 2018, while energy use for heating and domestic hot water was $76 \mathrm{TWh}$, corresponding to roughly $1 \mathrm{kWh} /($ person*hour), and the most common energy carrier for heating and domestic hot water was district heating at $47 \mathrm{TWh}$ [5]. This means that district heating corresponds to one third of the energy use in this sector. About one quarter of the fuels supplied to district heating (DH) in 2015 were from fossil sources [6], which means that GHG emissions from DH are important. About two thirds of the fuels supplied were biofuels, and the remaining part comes from various sources such as electricity, heat pumps, and waste heat [6].

District heating (DH) is highly developed in Sweden and can be considered to have reached a period characterised by maintenance (see Fig. 1.). During the last 20 years, there has been neither a large expansion nor steep reduction in supplied heating energy from $\mathrm{DH}$. 


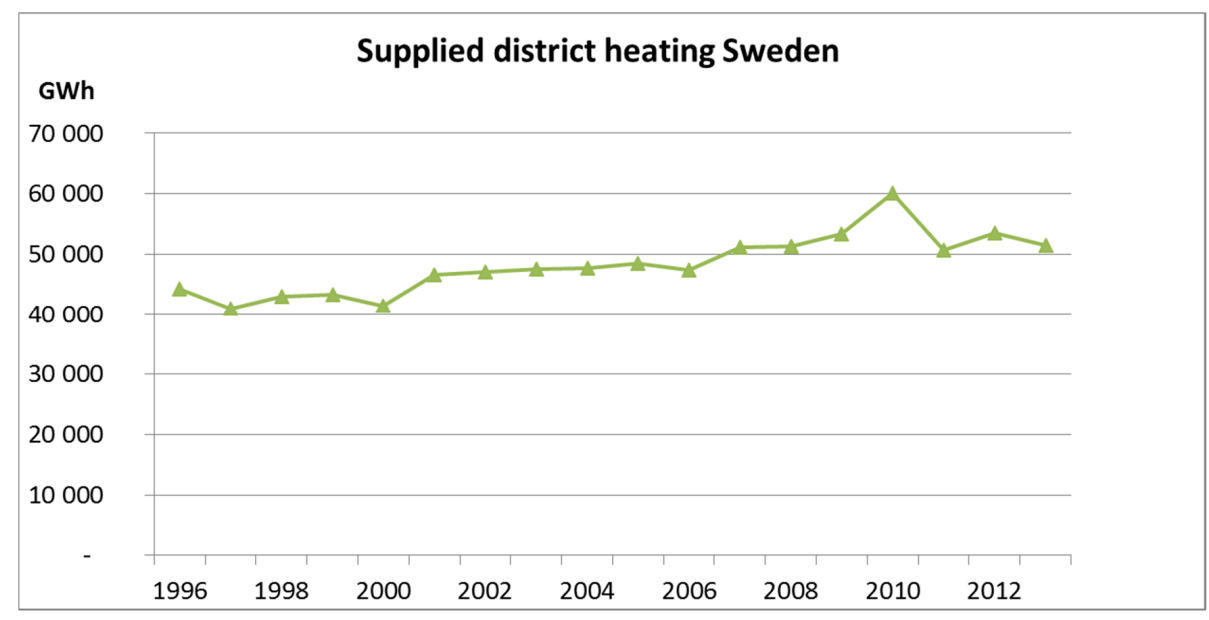

Figure 1. Supplied district heating in Sweden. The growth period for the district heating market is coming to an end and is moving into a period of maintenance. [6]. The peak in 2010 is caused by an unusually cold winter.

However, the fuel supply to the CHPs in these DH systems has changed. The two most important changes in the 45-year period presented in Fig. 2. are the removal of oil products and the increase of biofuels.

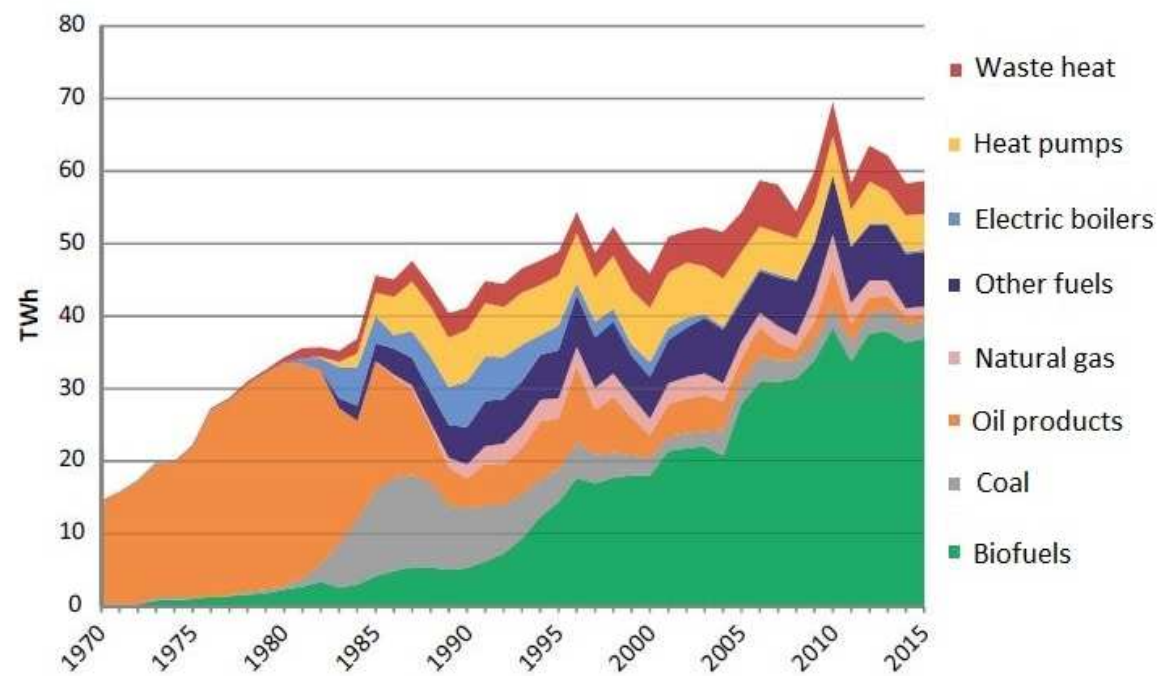

Figure 2. Fuel supply in district heating in Sweden 1970-2015. Source: Swedish Energy Agency. [5].

In 2015, biofuels had a $63 \%$ share of the fuel supply to district heating. The share of heat pumps has been reduced and electric boilers have almost vanished during the last 15 years. The use of household waste has increased over the last two decades, and several Swedish municipalities have household waste as the dominant fuel. In Fig. 2. household waste has a part in both "Biofuels" and "Other fuels". 
The combustion based electricity production in Sweden 2015 was $13 \mathrm{TWh}$, which can be divided into two categories, utility CHP with $8 \mathrm{TWh}$ and industrial CHP with 7 TWh [5]. The quota between electricity production and fuel supply for all Swedish CHPs and DHSs can then roughly be estimated to $13 / 60=0.22$. However, this figure should not be treated as a net production of electricity delivered to the electricity market, because some industrial CHPs are situated in industries with high internal electricity use, so these industries are sometimes even net electricity consumers, e.g. papermills. In general, investments in CHPs with high electrical efficiency have not been prioritised due to the low electricity price in Sweden, which has been a consequence of high volumes of hydropower and nuclear power.

The production volume in the Swedish district heating market will likely remain at about the same level as during the last decades. However, other changes are possible regarding e.g. technical components, fuels and system services.

Important issues for the future development of CHPs and DHSs are:

- Fuel use

- Losses

- Efficiencies for technical components

- System services to surrounding energy markets

All these issues have an impact on future $\mathrm{CO}_{2}$ emissions. Lund et al. [7] outlined the concept of 4GDH (4th Generation District Heating) where future energy systems are more integrated and with a high volume of fluctuating renewable energy sources such as wind, geothermal and solar power, together with residual resources such as waste and biomass. The future system services delivered from CHPs and DHSs will probably change and in this change lie both opportunities and challenges. In order to better adapt to fluctuating external conditions many CHPs need to invest in their energy conversion units. 


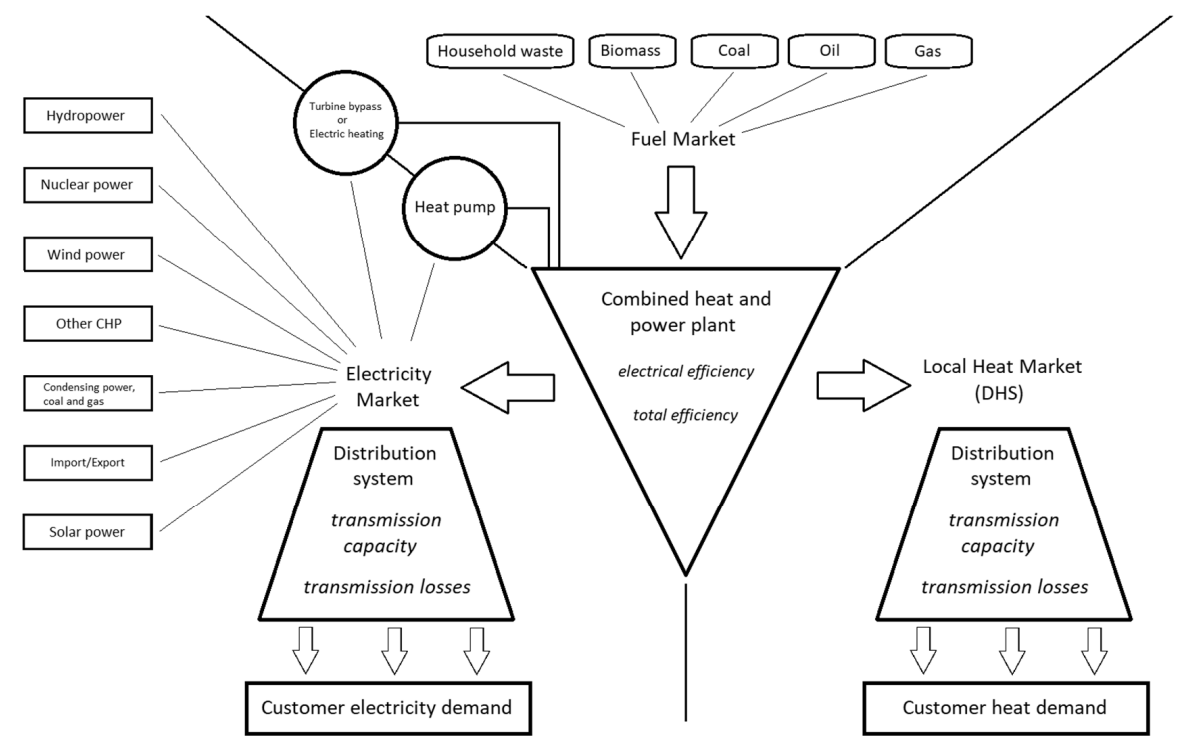

Figure 3. Schematic figure that illustrates the components in the studied regional energy system.

Fig. 3. is a schematic illustration of the regional energy system that is the studied object throughout this thesis. Important parts of this system are fuel resources, energy conversion units, distribution systems and customer demands. The fuel resources are used in the CHP in the centre of the picture, where the energy flow is divided into two parts: electricity and heat; these flows then enter their local distribution system. In general, the local heat demand defines how much power is needed from the CHP, and the input to the electricity market comes as a result of this heat demand. The quota between electricity production and heat production is specific for each CHP-DHS, and so is the fuel mix.

The left side of the picture presents other electricity producers in the Swedish electricity market, sorted in relation to yearly production with the producer with the largest production (Hydropower) at the top. However, for hydropower there is a large yearly fluctuation between a dry year and a wet year, e.g. 63 TWh in 2014 and 75 TWh in 2015. These fluctuations also have a strong influence on the import/export volume. Sweden is generally a net exporter of electricity but there are some exceptions. The last year with net import was 2010. [5].

The European Council has endorsed a binding EU target of at least a $40 \%$ domestic reduction in greenhouse gas emissions by 2030 compared to 1990 [8]. Electricity production is one of the major sources with $29.3 \%$ of the $\mathrm{CO}_{2}$ emissions in $\mathrm{EU}$ [9]. Hence, electricity production is identified as a major source of GHGs and investments in both production sites and distribution grids will probably change the dynamics of the European electricity market. CHPDHSs have a special role in this changing environment because they can be involved in energy conversion in both directions, heat to electricity and electricity to heat. Electricity to heat can be carried out with direct electric heating or by a heat pump. Heat pump is the preferred alternative given the higher efficiency of this technology. However, a heat pump has a higher installation cost so direct electric heating is sometimes the only option. 
The basic configuration of a CHP-DHS consists of a boiler, a turbine with generator and a heat distribution network. For peak load situations in the DHS there is often a heat only boiler installed (HOB). Other components can be added/integrated to form a more complex technological system. Many power plants have a Flue Gas Condenser (FGC) in order to preheat feedwater with heat from the flue gas. This component reduces heat losses, but it will not increase electrical efficiency. Components that increase electrical efficiency can be found in the turbine section of the plant. A more advanced turbine shaft has several different turbines on the same shaft using steam at different inlet pressures, a common configuration being HT-MT-LT (high pressure turbine, medium pressure turbine, low pressure turbine). For power plants with gas or oil as fuel, Combined Cycle Gas Turbine (CCGT) technology is available. The CCGT technology has a high electrical efficiency compared to other heat engines, with electrical efficiency in the range of 50-55 \% not uncommon [10]. In most parts of Sweden there is not a natural gas grid, but small volumes of biogas can be used in CCGT. In such a case it might be necessary to co-fire with oil to reach the minimum power for the gas turbine.

There are some import and export flows over national borders. However, this should not be exaggerated. 2015 was a record year, with Swedish net electricity exports of $22.6 \mathrm{TWh}$, corresponding to $14 \%$. So, the Swedish electricity market that year was $86 \%$ national [5]. In Great Britain the $10 \%$ threshold for imported electricity was reached in the first quarter of 2019 [11], meaning that the British electricity market is $90 \%$ self-sufficient.

Long distance power transmission will always be associated with energy loss in the grid. Losses in the Swedish power grid were $6 \%$ in 2015 [5]. With higher volumes of wind power, power transmission becomes a problem. Local use of excess wind power electricity is preferred to ease the strain on major high voltage cables. Moreover, when maximum grid capacity is reached then local electricity use might be the only available option.

The political uncertainty about the future for nuclear power in Sweden has for several decades created doubts concerning other power investments in the Swedish power market (see for example [12]). Also, this issue is and has been hampering CHP investments. If today's level of Swedish nuclear power is kept Sweden will probably remain an area with relatively low electricity prices and an area with net electricity export. A future scenario with less nuclear power and more wind power will create another market situation with more intermittent power production. In this scenario there will probably be a more fluctuating electricity price, but it is hard to forecast the average price level.

A trend in the transport sector is the increased market penetration for electric vehicles (EV). Graabak et al. [13] examine a scenario with $100 \%$ EV penetration in the Nordic region (Denmark, Norway, Sweden and Finland) by 2050, and they conclude that the complete electrification of the private passenger fleet increases the yearly power demand in the Nordic region by around $7.5 \%$. The increased power demand will have to be compensated with an equally large increase in electricity production. It is natural to regard this increase as a marginal effect in the electricity market, meaning that the marginal electricity production in the power market should serve as a reference when evaluating this technological change.

Another probable change in the future fuel and electricity market is an increasing amount of biogas use. [14]. In 2016 biogas production in Sweden was 2 TWh [15], which corresponded to $0.3 \%$ of total energy use [6]. The most common use of biogas was as vehicle fuel (1145 
$\mathrm{GWh}$ ), while $400 \mathrm{GWh}$ was used for heating [15]. In a modelling assessment of cost-effective biogas utilisation Börjesson et al. [16] conclude that only about 10-16\% of the technical biogas potential will be utilised without subsidies. However, they predict about $90 \%$ biogas utilisation with subsidies of between 40-60 EUR/MWh. Biogas could be used in DH networks, both in CHPs and in HOBs.

The district heating networks are a great resource with the ability to assist in future heat exchanging services. Moreover, a technological change away from DH would be very complicated and demand massive resources. Therefore, in this thesis the DH infrastructure is taken as a given. With that assumption and looking into the future there are two major questions. What is the role for CHP and DHS in the future Swedish energy system? And what kind of investments are beneficial for lower $\mathrm{CO}_{2}$ emissions? 


\subsection{Aim and research questions}

The aim of this thesis is to describe and evaluate the fuel-based energy flows in a regional energy system in Sweden. The CHP (combined heat and power) plants are central units in regional energy systems and are therefore at the centre of attention throughout this thesis. An important focus in this thesis is on evaluating how changes in one regional energy system have implications in surrounding energy systems. Two research questions have been considered in order to guide the research process.

\section{Research question 1:}

How can a regional combined heat and power plant (CHP) in a district heating system (DHS) be improved to reduce global carbon dioxide emissions?

\section{Research question 2:}

How can a systems approach help to assess how actions taken in a regional energy system have implications in surrounding energy systems?

\subsection{Scope and delimitations}

The thesis examines how some strategic changes in a regional energy system with CHP and DHS affect the produced services and the $\mathrm{CO}_{2}$ emissions. Each CHP station has a unique combination of heat load, fuels, boilers, turbines etc. In this project the combined heat and power station managed by Tekniska verken in Linköping municipality has been modelled. Efficiencies for turbines and flue gas condensers have been studied. System effects in electricity market as a result of higher or lower electricity production have been studied. System effects in fuel markets as a result of power plant fuel savings have also been studied.

There are many details in the physical domain that are omitted, in some cases by choice, and in some cases by necessity. DHS pipe structure is not included in the study. Building costs and life-cycle costs are omitted. The focus is instead on the overall efficiency potential. This kind of top-down model should not be used to forecast absolute emission values; the numerical uncertainties are too high for this use. A better approach is to use the model results to strategically compare different developing pathways. However, even with this use, input parameters are crucial for the quality of the strategic assessment. The input parameters for the case studies in this thesis have been a mixture of direct measurements (e.g. power plant data) and parameter values based on literature sources.

\subsection{Paper overview}

\section{Paper I}

Rosén, T., Ödlund, L. (2019). Active Management of Heat Customers Towards Lower District Heating Return Water Temperature. Energies, Vol 12, Iss 10, p 1863 (2019). 
This article explores how supply water temperature and return water temperature affect the efficiencies of different CHP components. A case study was performed for the DHS in Linköping municipality. In this study, the optimisation software Model for Optimisation of Dynamic Energy Systems with Time-dependent components and boundary conditions (MODEST) was used. The DHS system was represented in the model by four different kinds of nodes - fuel nodes, conversion nodes (boilers, turbines, and flue gas condensers), demand nodes (traditional heat customers and low-grade heat customers), and waste nodes (electricity production and heat losses). The power plants were described in terms of the efficiencies, maximum capacity, temperature-dependent power-to-heat ratio, and temperature-dependent flue gas condenser efficiency.

With the strategic introduction of low-grade heat customers, the return water temperature can be lowered and, to some extent, controlled. With the heat customers connected in parallel, which is the traditional setup, return water temperatures can only be lowered at the same rate as the heat customers are improved. The active management of some customers can lower the return water temperatures faster and, in the long run, lead to better controlled return water temperatures. Active management is defined here as an adjustment of a domestic heating system in order to improve DHS efficiency without affecting the heating service for the individual building. The opposite can be described as passive management, where heat customers are connected to the DHS in a standardised manner, without taking the overall DHS efficiency into consideration. The case study in this article shows possible efficiency gains for the examined DHS of around $7 \%$. Looking at fuel use, there is a large reduction for oil, with 10-30 \% reduction depending on the case in question, while the reduction is shown to be largest for the case with the lowest return water temperature. The results also show that efficiency gains will increase electricity production by about 1-3\%, and that greenhouse gas (GHG) emissions are reduced by 4-20\%.

\section{Paper II}

This article explores a new conversion pathway for the regional biogas in Linköping municipality. Linköping municipality introduced biogas driven buses to the regional transport system in 1997 and since 2015 all buses in the municipality have run on biogas. Biogas is a renewable fuel and by replacing fossil fuels it can help to lower net $\mathrm{CO}_{2}$ emissions. However, Internal Combustion Engines (ICE) in buses, using biogas or fossil fuels, still have a rather low efficiency in the range of 15-30\%. Much of the energy content in the fuel will be emitted as heat through the exhaust pipe. If the combustion of biogas instead takes place in a Combined Cycle Gas Turbine connected to the district heating system (DHS), this heat can be used for heating purposes. This could be a feasible solution if the transport system instead used electric buses charged with electricity generated by the combined cycle gas turbine.

This article has a top-down perspective on the regional transport system and the regional district heating system (DHS) in Linköping municipality. Two alternative systems are compared regarding $\mathrm{CO}_{2}$ emissions, electricity production and component efficiencies. The first system that is studied is in operation today and it uses biogas produced in the region as fuel in the ICE biogas buses. In parallel the combined heat and power (CHP) system delivers electricity and heat to households in the region. The second system that is studied is a system with electric buses and a CHP system that uses biogas in the combined cycle turbine to 
deliver electricity and heat to the regional power grid and DHS. The use of this turbine will alter the fuel mix for the DHS when heat from biogas combustion competes with heat produced by waste incineration.

The study shows positive effects if biogas use is changed from being used in ICE in buses to being used in the CCGT in the CHP-DHS. The study indicates that improved biogas use could lower $\mathrm{CO}_{2}$-eq emissions by 2.4 million $\mathrm{kg}$ annually by using a better fuel-energy pathway.

\subsection{The research project "Control strategies for district heating"}

In the beginning of my research I was involved in a research project called "Control strategies for district heating" (original title in Swedish: "Storskalig styrning av fjärrvärme"). Some of the content in this thesis was previously published in Swedish in the report from this research project [17]. The research project was conducted in collaboration with several Swedish power companies and the aim of the project was to assess future control strategies for district heating. Both internal issues for power plants and external conditions created by the heat market and the electricity market were discussed in research workshops.

The main finding from this research project was that the valuation method for CHP electricity production is crucial. A method using European marginal electricity production highlights the quality aspect of Swedish CHP electricity production. With only a local perspective, general fuel savings and efficiency gains are not acknowledged as clearly. The studied CHP-DHS in Linköping municipality can be improved with higher electrical efficiency for steam turbines, which would be beneficial in cutting global $\mathrm{CO}_{2}$ emissions. 


\section{Theoretical background}

Handling the flow of energy, fuels and emissions through a regional energy system constitutes a complex subject. The complexity arises from the fact that there is not just a single system, there are systems of systems, all affecting each other in many ways. The fuel market can be regarded as one system, but on the other hand it can also be regarded as several different systems interlinked, a biomass market, an oil market, a household waste market and so forth. Making things even more complicated, it also must be stated that the regional energy system studied is not detached from the surrounding world. In this complex situation it is difficult to achieve a good model that can be used to evaluate system performance. In this chapter a theoretical background is given for the central subjects in this thesis and the methods that have been used to analyse them.

\subsection{Top-down modelling}

The essential methodological principle applied in this thesis can be described as top-down modelling. This modelling process starts with a whole - the regional energy system. The most simplistic model of this system is just a "black box" with fuel as input and heat and electricity as outputs. In order to create a more sophisticated model the "black box" must be divided into finer details. Fig. 4. illustrates how the energy system is described in finer and finer detail. In the first step there is a "fuel conversion box", this part of the model is then elaborated to four boxes: boiler-turbine-generator-district heating. These components can be divided further to create an even more detailed model. When working top-down, there is a movement from the general to the specific. 


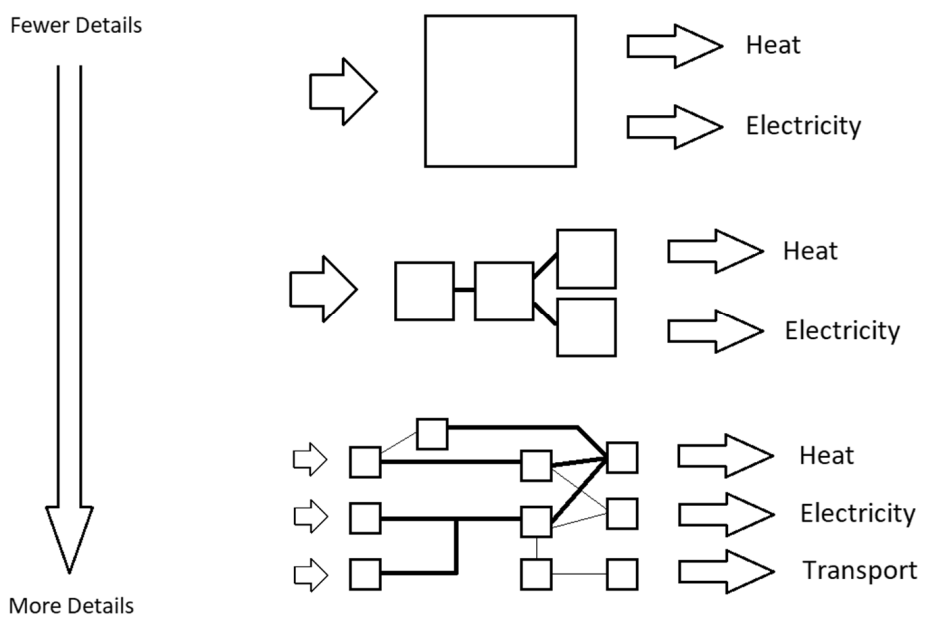

Figure 4. Top-down modelling of a regional energy system. Illustration of the model elaboration process.

This process of elaboration in finer and finer detail can also be applied in the time domain. Yearly energy use can be divided into monthly energy use, weekly energy use, daily energy use and so forth. In Paper I the model used had 23 nodes (fuel sources, boilers, turbines, flue gas condensers, heat demand) and 96 time-steps to represent the energy system for one year. In Paper II the model used had 32 nodes (fuel sources, boilers, turbines, flue gas condensers, heat demand, bus transport node, transport demand) and 96 time-steps to represent the energy system for one year. Input data regarding efficiencies for each node/component were from measurements or literature sources. By contrast, these input data sources are often retrieved from research working in the other direction - bottom-up. Using the classification method proposed by Hall et al. [18] the method used in this thesis might be classified as a Hybrid approach, hence it is neither a "true" Top-down or Bottom-up approach. However, the model optimisation tool being used: MODEST ("Model for Optimisation of Dynamic Energy Systems with Time-dependent components and boundary conditions") was originally developed to be a top-down tool.

\subsubsection{MODEST}

In this thesis, the optimisation software "Model for Optimisation of Dynamic Energy Systems with Time-dependent components and boundary conditions" (MODEST) was used. The CHPDHS system was represented in the model by four different kinds of nodes - fuel nodes, conversion nodes (boilers, turbines, flue gas condensers, buses, and heat pumps), demand nodes (heat demand, transport demand), and waste nodes (electricity production and heat losses). The power plants were described in terms of the efficiencies, maximum capacity, temperature-dependent power-to-heat ratio, and temperature-dependent flue gas condenser efficiency. MODEST is a top-down tool that can be used to represent the largest flows in an energy system. The top-down method is beneficial for analysing "the whole picture". The modelling starts at the top, in this case a regional energy system, and then moves down in finer and finer detail. At a certain degree of system detail, one needs to stop, but there is no distinct way to choose this level. In the time domain, this study starts with year, then moves to months, weeks, and days, and then stops. In the physical domain, this study starts with CHP- 
DHS in a municipality, then moves to supply side, power plants, and power plant components, and then stops.

The model's objective is to optimise the energy system with the lowest possible system cost and meet the demand from the demand node/nodes for all included time-steps. Hence, the results from the MODEST model will represent an optimum production mix in terms of cost efficiency. The MODEST model is described in detail by Henning [19]. Several authors have used MODEST to analyse DHS, for example Lidberg et al. [20], Gebremedhin [21] and Blomqvist et al.[19]. MODEST is a top-down tool that can be used to represent the largest flows in an energy system. In section 3.1 there is more information about the models and the case studies. 


\subsection{To measure system performance}

In the early 1970s Ehrlich and Holdren [20] devised a simple equation identifying three factors that created environmental impact. This equation has since become known as the "IPAT equation". The environmental impact (I) is expressed as the product of population (P) times affluence (A) times technology $(\mathrm{T})$ : $\mathrm{I}=\mathrm{P}^{*} \mathrm{~A} * \mathrm{~T}$. Depending on context this equation has been used in different ways, sometimes to describe the importance of the size of the global population and how this determines the environmental impact, other times as a means to show the importance of technology. Chertow [21] describes how the use of this equation has taken different forms through the first 30 years of its lifetime. Both technical optimists and technical pessimists have used this equation, the first to underscore the technology as a critical factor in environmental improvement and the latter to describe e.g. the dangers of consumerism (see for example Kates [22]).

The general method when using the IPAT equation can also be used for a vast number of other equations. Intensities are multiplied in order to calculate the physical property of interest. Three examples of this method can be seen below.

$$
\text { Emissions from cars }=\text { number of cars } * \frac{\text { emissions }}{\mathrm{km}} * \frac{\mathrm{km}}{\mathrm{car}}
$$

Energy input from solar panels $[W h]=$ number of panels $* \frac{W h}{\text { area }} * \frac{\text { area }}{\text { panel }}$

Transport service from buses $[$ person $* \mathrm{~km}]=$ number of buses $* \frac{\text { person }}{\mathrm{km}} * \frac{\mathrm{km}}{\mathrm{bus}}$

The intensity factors in these equations are measurements of system/component performance. For example, a top performing car has a low value for emissions $/ \mathrm{km}$, a good solar panel has a high value for $\mathrm{Wh} /$ area and so forth. The usage of intensity factors is practical when evaluating different services and it has become a very common way of communicating environmental performance to the consumer market. One example of this is the $\mathrm{CO}_{2}$ emission limits for cars issued by the Swedish Government - there are limits in several steps that define the tax level as a function of $\mathrm{CO}_{2}$ emissions [g/km] [23].

A major benefit of these kinds of equations is that they can be utilised to communicate both quality and quantity aspects of an issue. The product in the equation is affected by both a quality term and a quantity term. However, when looking only at the product of the factors then improvements in one factor could mask a negative trend in another, e.g. better car engines can reduce emissions from each individual car, but at the same time an increasing number of cars might keep the total emissions at a steady level.

In this thesis several intensity factors are used, both as input data and as internal parameters in the MODEST model. Some examples of intensity factors are presented in Table 1. 
Table 1. Examples of intensity factors.

\begin{tabular}{|l|l|l|}
\hline Intensity factor & Kind of data & Dimension \\
\hline Turbine efficiency & $\begin{array}{l}\text { Internal parameter in } \\
\text { model }\end{array}$ & $\%$ \\
\hline $\begin{array}{l}\text { Flue gas condenser } \\
\text { efficiency }\end{array}$ & $\begin{array}{l}\text { Internal parameter in } \\
\text { model }\end{array}$ & $\%$ \\
\hline Biomass emission value & External value & $\mathrm{kg} \mathrm{CO}-$ eq $/ \mathrm{MWh}$ \\
\hline DH supply temperature & $\begin{array}{l}\text { Internal parameter in } \\
\text { model }\end{array}$ & ${ }^{\circ} \mathrm{C}$ \\
\hline $\begin{array}{l}\text { Electric bus engine } \\
\text { efficiency }\end{array}$ & External value & $\mathrm{kWh} / \mathrm{km}$ \\
\hline
\end{tabular}

One part of the model used in Paper II can serve as an example of a chain of intensity factors. Fig. 5. shows four conversion steps in the model. Four consecutive conversions are done in serial connection. If all intensities are known, then the resulting emission intensity can be calculated [kg CO 2 -eq/hour].
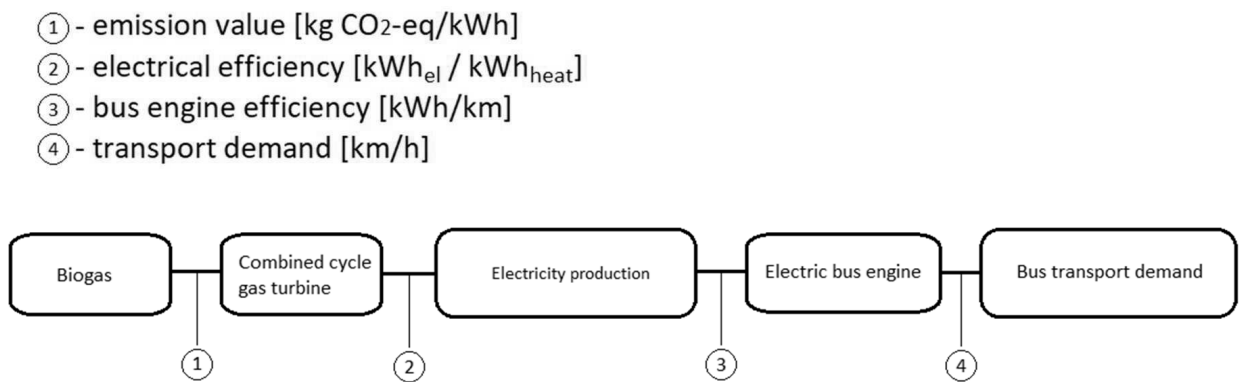

Figure 5. Illustration of a chain of intensity factors.

In a more elaborated study this chain of intensity factors could be even longer. The third conversion step in the chain could be elaborated from $[\mathrm{kWh} / \mathrm{km}]$ to $[\mathrm{kWh} /(\mathrm{km} *$ person $)]$ * [persons]. This elaboration would enable a comparison between personal car use and public transport by bus, where the former mode of transport generally has a higher $\left[\mathrm{kWh} /\left(\mathrm{km}^{*}\right.\right.$ person $\left.)\right]$ than the latter. However, this elaboration would also imply a need for more measurements and/or more assumptions, which also complicates the analysis. Hence, there is a natural trade-off between details in measurements and the analytical questions that can be analysed. 


\subsection{CHP and heat engine efficiencies}

The CHP technology has the principal flow process illustrated in Fig. 6. There is a primary energy source in the form of chemically bound energy in the fuel. This energy is converted into heat energy in the combustion process in the boiler. In this way a mass flow of fuel and air generates a mass flow of energy dense steam. The steam is led through a steam turbine which, by means of a generator, converts parts of the energy into electric power. In the next process step the primary process steam is cooled in a condenser which conveys heat energy to the district heating network by means of distribution pumps and heat exchangers. The primary flow loop is closed when feedwater pumps push back the cooled process water from the condenser into the boiler. More detailed descriptions of this process can be found in for example [24] or [25].

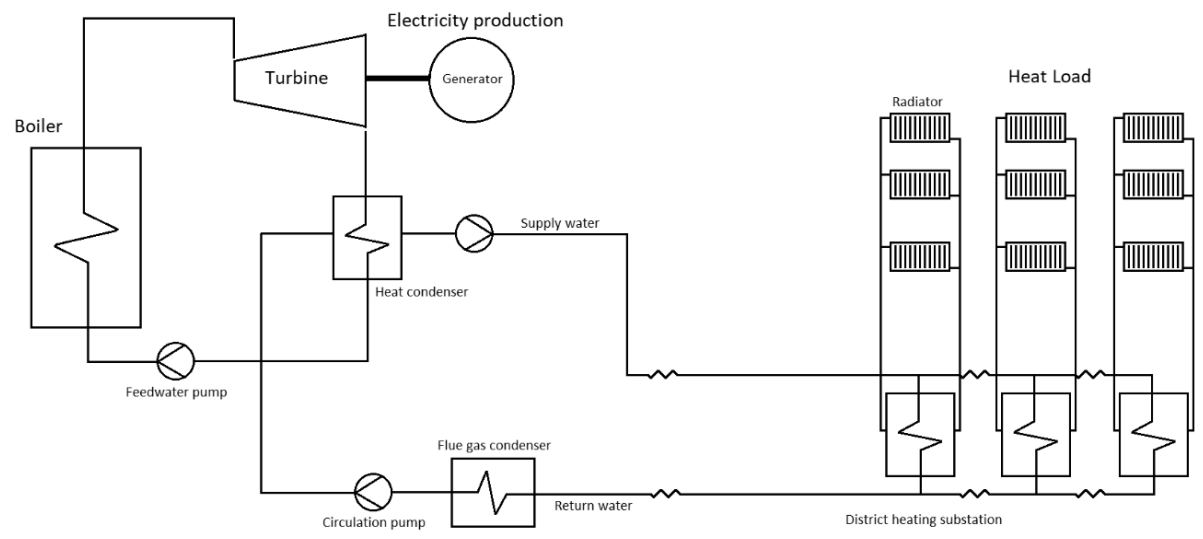

Figure 6. Schematic illustration of CHP-DHS process.

\subsubsection{Electrical efficiency}

The theoretical limit for a steam turbine's electrical efficiency is set by the available heat fall, i.e. the difference between the inlet temperature to the turbine and the outlet temperature from the turbine condenser. This theoretical limit for electrical efficiency is called the Carnot efficiency and is defined by Eq. 1.

$$
\begin{aligned}
& \text { Equation } 1: \eta=\left(\mathrm{T}_{\text {Hot }}-\mathrm{T}_{\text {Cold }}\right) / \mathrm{T}_{\text {hot }} \\
& \eta=\text { Carnot efficiency } \\
& \mathrm{T}_{\text {Hot }}=\text { The temperature (in Kelvin) at which the high temperature reservoir operates (the boiler) } \\
& \mathrm{T}_{\text {Cold }}=\text { The temperature (in Kelvin) at which the low temperature reservoir operates (the condenser) }
\end{aligned}
$$

The Carnot efficiency constitutes an important theoretical boundary. However, in practice, real steam turbine plants are far from this theoretical boundary. Many practical hindrances limit the efficiency, e.g. unavoidable heat losses, turbulence in different parts of the flow process, and heat resistance in construction materials. Heat losses in the process can be kept 
down by preheating the feedwater with bleed steam from the turbine section. In this way losses are avoided because less heat is ejected from the condenser. A steam turbine with many preheating stages has better fuel economy and higher electrical efficiency. The most efficient, and most expensive, steam turbines are located at nuclear power plants and have an electrical efficiency of 30-35\% with 4-6 preheating stages. These values for electrical efficiencies must be considered high, taking into account that the temperatures for the boilers are as low as $286^{\circ} \mathrm{C}$.

Combustion based steam turbine plants have a considerably higher available heat fall but due to lower production volumes the higher investment cost for better turbines can be hard to bear for the power plant owner. With a CHP plant that can also get revenue for emitted heat it becomes natural to choose a simpler turbine plant. In areas where there is a low electricity price it becomes extra hard to justify investments in expensive turbine hardware with high electrical efficiency.

The electrical efficiency of the process is mostly affected by the steam turbine construction and the combustion temperature, but also the condenser temperature. Here, there is a connection to the supply temperature for the DH heat load; a lower supply temperature in the DHS will increase the electrical efficiency of the steam turbine. Evaluated as part of the heat fall $\left(\mathrm{T}_{\mathrm{Hot}}-\mathrm{T}_{\mathrm{Cold}}\right)$ then this potential difference in supply temperature $\left(\mathrm{T}_{\mathrm{Cold}}\right)$ is a relatively small part of the improvement potential for most turbine plants. For power plants that do not have a high-pressure turbine, a reconstruction where a high-pressure turbine is installed would increase the heat fall by more than $100^{\circ} \mathrm{C}$. This increase in heat fall is considerably more than the increased heat fall created by a decrease in supply temperature. Fig. 7. illustrates the heat fall in the steam turbine process.

$$
\begin{aligned}
& \text { Calculation examples Carnot efficiency: } \\
& \mathrm{T}_{\text {Hot }}=400^{\circ} \mathrm{C}, \mathrm{T}_{\text {Cold }}=90 \rightarrow \text { Carnot efficiency: } 0.46 \\
& \mathrm{~T}_{\text {Hot }}=500^{\circ} \mathrm{C}, \mathrm{T}_{\text {Cold }}=90 \rightarrow \text { Carnot efficiency: } 0.53 \\
& \mathrm{~T}_{\text {Hot }}=400^{\circ} \mathrm{C}, \mathrm{T}_{\text {Cold }}=70 \rightarrow \text { Carnot efficiency: } 0.49 \\
& \mathrm{~T}_{\text {Hot }}=500^{\circ} \mathrm{C}, \mathrm{T}_{\text {Cold }}=70 \rightarrow \text { Carnot efficiency: } 0.55
\end{aligned}
$$




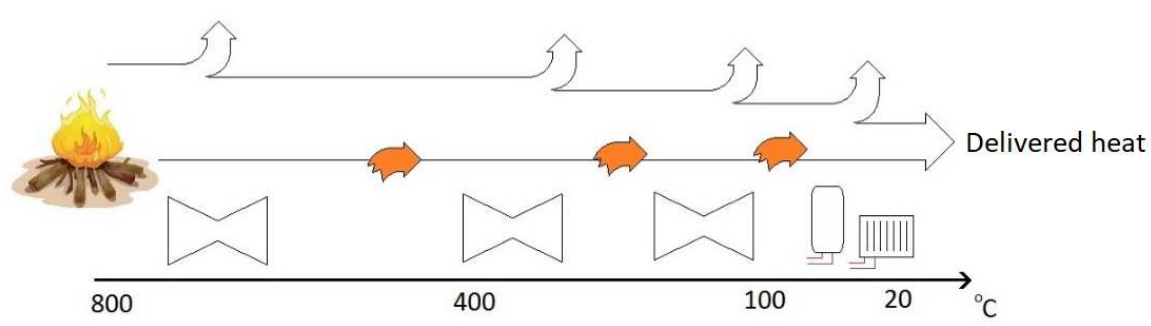

Turbine working zone

Extended turbine working zone

Figure 7. Illustration of the heat fall between the primary heat source and the final heat customer.

Increased Carnot efficiency illustrates a possibility of achieving higher electrical efficiency. However, the actual electrical efficiency for a specific turbine plant is dependent on turbine technology and preheater arrangements. Fig. 8. illustrates measured electrical efficiency for a steam turbine operating with different supply temperatures to the DHS.

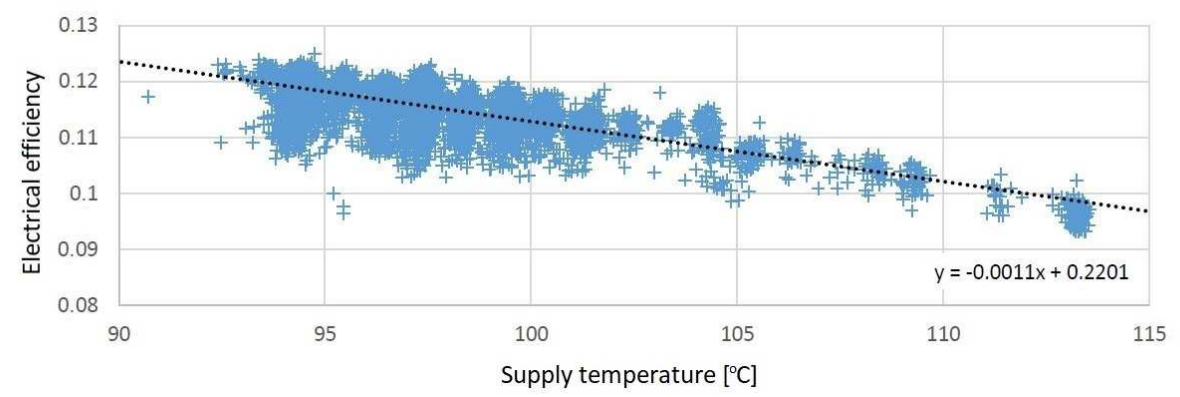

Figure 8. Measured efficiencies for KV50 turbine - waste incineration plant.

Through this temperature dependency at the turbine plant there is a link to the efficiency of the DHS. A DHS with higher supply temperature will operate a steam turbine with lower electrical efficiency. 


\subsubsection{Heat losses}

The basic energy flow in the CHP process is from the fuel combustion in the boiler through different sub-systems and finally to heat customers and surroundings. Table 2 . shows the heat losses from this process.

Table 2. Heat losses in different sub-systems in the CHP-DHS.

\begin{tabular}{|l|l|c|}
\hline Heat loss & Sub-system & Temperature interval [ ${ }^{\mathbf{0}} \mathbf{C}$ ] \\
\hline Distribution loss & District heating piping & $40-110$ \\
\hline Flue gas loss & Chimney & $40-70$ \\
\hline $\begin{array}{l}\text { Heat loss in district heating } \\
\text { substation }\end{array}$ & District heating substation & $40-110$ \\
\hline Heat loss in buildings & Buildings & $20-40^{*}$ \\
\hline Storage loss & Accumulator & $40-100$ \\
\hline Heat loss in CHP processes & CHP power plant & $40-800^{* *}$ \\
\hline $\begin{array}{l}\text { * Losses can be divided further, e.g. into ventilation losses and transmission losses } \\
\text { ** Upper limit depending on type of boiler }\end{array}$
\end{tabular}

Heat losses are a natural part in all steps of the CHP process. At the power plant and in the distribution grid all losses can be regarded as negative, because all lost heat could have been delivered to the customer. Losses in the distribution network are affected by the system temperatures, supply temperature and return temperature, where lower temperatures give lower losses. For more detailed information about distribution losses, read for example [25] or [26].

On the customer side, the situation is more complicated because low heat losses in winter can lead to too high indoor temperatures in the summer. La Fleur et al. [27] and Chvatal et al. [28] have examined indoor climate and they reach similar conclusions; when buildings are very well insulated then the indoor environment is improved in the winter, but during summer high temperatures might reduce thermal comfort. The general trend in newly produced buildings is for heat losses to become lower. For the DH supplier this means a lower heat load per floor area $\left(\mathrm{kWh} / \mathrm{m}^{2}\right)$.

In a large DHS system with several production units a loss is added that comes when peak load units are used. Peak load units are often HOBs with higher heat losses than the base load units. Load control in order to avoid using peak load units can reduce heat losses for the whole DHS.

A large source of heat loss for fuel combustion boilers is the heat loss from the flue gas. A common arrangement is to extract some of this heat in a flue gas condenser (FGC). In the next section FGC will be described in more detail. 


\subsection{Flue gas condenser efficiency}

Flue gas condensation is a process where flue gas is cooled below its water dew point and the heat released by the condensation of water is recovered as low temperature heat. Flue gas condensation reduces the heat loss from the flue gas. However, even for power plants with FGC there is a substantial heat loss through the flue gas. The coolant that recovers the heat from the flue gas is usually the district heating return water. The temperature of the return water affects the efficiency of the FGC process. Figure 9 shows measured efficiency samples from the flue gas condenser at KV 61 - waste incineration unit. The temperature dependency is obvious although a rather high data dispersion is present.

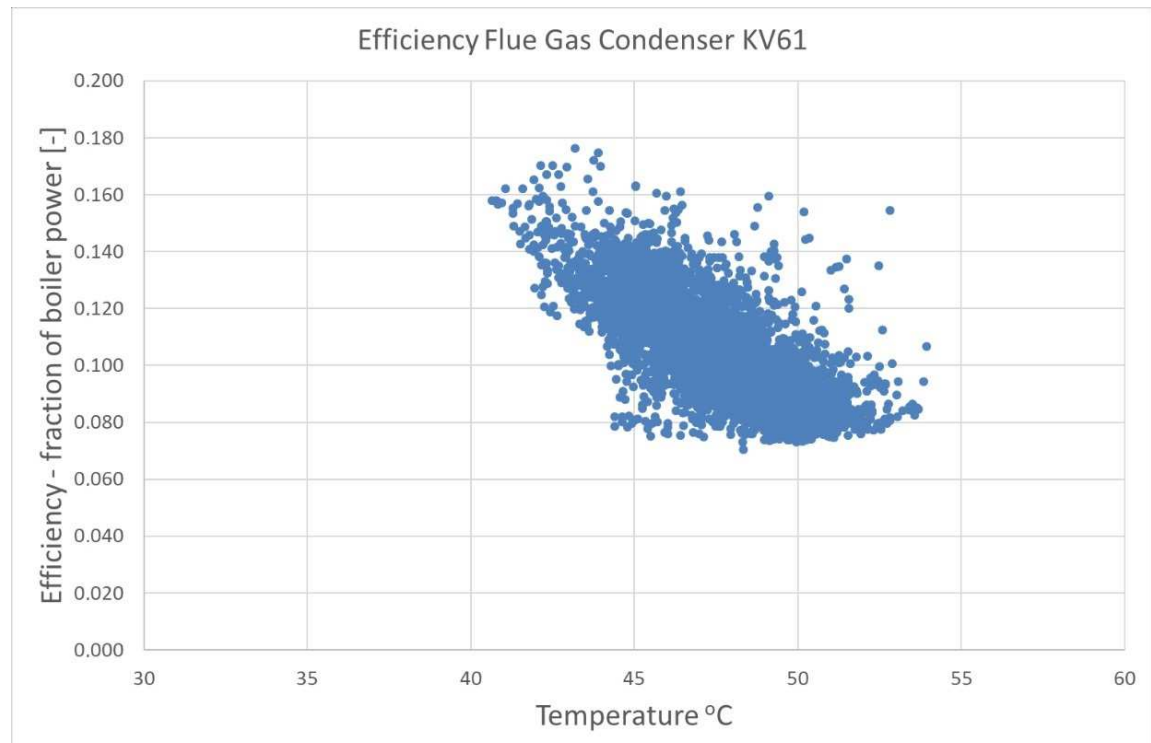

Figure 9. Flue gas condenser efficiency for KV 61 waste incineration unit (figure from Paper I). Samples have been collected over several years and during different operation modes. There are variations in boiler power, fuel moisture, outdoor pressure, and so on. This gives a considerable data dispersion, but the temperature trend is clear: lower district heating return temperature gives higher FGC efficiency.

If the heat load in the DHS could produce a lower return water temperature, it would be beneficial for the FGC efficiency and consequently for the overall DHS efficiency. Hence, in the DH process there is a positive feedback loop, whereby an efficient DH substation will create a low return water temperature, which in turn will improve the efficiency of the power plant FGC. With a substantial part of the heat delivered to the DHS, FGC efficiency becomes an important matter for the efficiency of the whole system. 


\subsection{Heat pumps in DHS}

The operating principle of a heat pump is based on the physical property that the boiling point of a fluid increases with pressure. By lowering the pressure, a medium can be evaporated at low temperatures while an increase in pressure will lead to a high boiling point. A heat pump has four main components: evaporator, compressor, condenser and expansion device. The parts of the heat pump are shown schematically in Fig. 10. The refrigerant is the working fluid that passes through all these components. In the evaporator, heat is extracted from a heat source (air, ground, lake or river). The compressor increases the pressure of the working fluid. In the condenser this heat is delivered to the consumer at a higher temperature level. Electrical energy is required to drive the compressor and this energy is added to the heat that is available in the condenser. The efficiency of the heat pump is denoted by its coefficient of performance (COP), defined as the ratio of total heat delivered by the heat pump to the amount of electricity needed to drive the heat pump. The COP of heat pumps varies considerably but most heat pumps have a COP in the range between 2.5 and 4.0. More detailed descriptions of this process can be found in [24] or [29], for example.

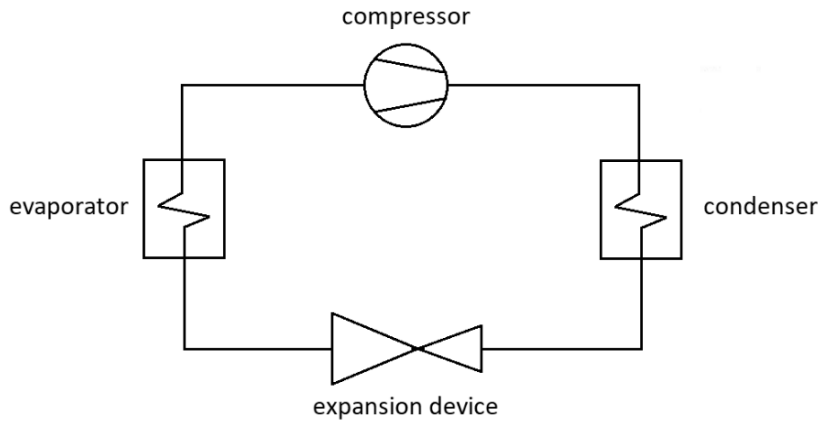

Figure 10. Schematic illustration of the heat pump process.

In a DHS use of heat pumps can be an interesting option if there is a low temperature heat source available, for example a river or a lake. Østergaard et al. [30] describe how the primary energy consumption for Frederikshavn, Denmark can be reduced from $758 \mathrm{GWh}$ to $560 \mathrm{GWh}$, mainly through changes in the production system. One of the proposed changes to achieve this was the introduction of heat pumps in the regional DHS. The use of heat pumps in DHSs will consume some of the produced electricity from the CHP plants, but the overall fuel use in the regional system will be reduced. The (optimal) trade-off between higher electricity production and better fuel economy has no general answer, but depends on the surrounding electrical grid, marginal electricity production and marginal fuel use. All these considerations are thus dependent on local circumstances. 


\subsection{Three connected markets}

Daily operation of the CHP affects surrounding energy markets; the fuel market is affected by the fuel choice and the amount of fuel used, while the electricity market is affected by the CHP power profile and the amount of electricity delivered. The heat load in the DHS defines the lower limit for heat production in the CHP plant. Changes in the CHP operation affect more than just internal parameters, e.g. local emissions and component efficiencies. There are also implications for surrounding markets. Increased electricity production for one power plant in the electricity market can result in decreased power production in other power plants. Moreover, operating conditions change when market conditions change. For example, fuel price changes could result in a lower heating price, but that is not certain - a lack of competition in the heating market might also hinder that price reduction.

Studies of market effects and system studies constitute a difficult field where unfortunate assumptions or system boundaries can lead to misleading conclusions, so a system perspective with well-considered boundaries is extremely important (see, for example, Churchman [31]).

\subsubsection{The Fuel Market}

The local emissions of $\mathrm{CO}_{2}$ can be calculated from characteristics for each fuel. Coal has the highest emission value followed by oil and then gas, waste incineration has a lower emission value and biomass is normally calculated with a very low emission value. However, if the natural limitations in the fuel market are included in the analysis then it becomes more difficult.

Because of the global interest in $\mathrm{CO}_{2}$ emission reduction, many power companies have begun to switch fuel. For example, one of Great Britain's largest coal power plants, Drax Power Station, with an electrical production capacity of $6 * 600 \mathrm{MW}$, has now switched to a fuel mix where more than a $50 \%$ share is wood pellets [32]. With many actors making similar choices, there is pressure on the biomass market. In an article about biomass fuel potential Schueler et al. [33] conclude that only $10 \%$ of the biomass fuel potential can be regarded to be without sustainability concerns (such as for example biodiversity and deforestation). Hence, $90 \%$ of the biomass fuel potential should not be regarded as an unproblematic fuel source. In a study on how different renovation measures for rental housing with district heating affect carbon dioxide emissions, Lidberg et al. [34] conclude that the valuation of biomass as fuel is crucial for the net result of the renovation measures. They conclude that if biomass is treated as a limited resource, the renovation measures result in emission reductions for all cases studied, but the opposite applies if the biomass is not seen as limited.

Waste as fuel is a particularly difficult subject that is addressed by many other authors. A report from IVL examines the content of the waste (IVL Swedish

Environmental Research Institute [35]), and Björklund et al. examine the taxes connected to waste incineration [36]. Covering all the aspects of waste incineration in this thesis would be far too complex. Hence, in this thesis, waste is treated as a fuel with associated emissions, i.e. without upstream market effects. 


\subsubsection{The Electricity Market in the Nordic region}

The electricity market is a complex market where there is a relatively extensive exchange over national borders. In 2015 Sweden had electricity production of $158.5 \mathrm{TWh}$, exports of 35.2 TWh, imports of 12.6 TWh and thus net exports of 22.6 TWh [37]. The extensive exchange over national borders implies that production and consumption should be evaluated in a larger system than only a national one.

Wind power and solar power are intermittent power sources. In the electricity grid these power sources act as disturbance signals that other power sources must regulate. Nuclear power plants serve as base load and are normally operated at full power. Today, CHP is normally operated entirely based on local heat demand, but with some production planning where electricity back-up and heat accumulation occur. Hydroelectric power stations are responsible for the regulatory capacity in the electric power market. Norwegian and Swedish hydroelectric power plants have a production plan covering one whole year; typically the water reservoirs are filled during spring and summer and emptied during winter.

Due to the extensive exchange over national borders, it is a common assumption that coalfired condensing power plants constitute the operating margin even in the Nordic region. However, that assumption is not always correct. With an increased volume of wind power in the Nordic countries, transmission capacity in the networks has become a limiting factor during windy days. Ringhals nuclear power plants reduced their output by a total of $0.4 \mathrm{TWh}$ for power balance reasons during 2015 [38] (despite the fact that Ringhals 2 was shut down throughout that year [38]). This exemplifies that on several occasions nuclear power is the marginal power instead of coal condensing power.

A report from the Swedish Energy Market Inspectorate states that the transmission links between the three Nordic bid areas SE4, DK1, DK2 and Germany are frequently restricted due to excess renewable power in northern Germany. This happens because internal bottlenecks in the German network are being "moved" to the border [39]. In these situations, coal power producers south of the internal German bottleneck are "protected" from electricity imports from the north.

Alternative electricity generation is an important parameter when assessing environmental performance for different system changes. Gode et al. [40] recommend the use of marginal electricity when changes in electricity use are analysed, and mean values when distributing emissions between actors.

\subsubsection{The Heat Market}

In this thesis, the heat market is mostly treated as an external demand for the CHP-DHS. On the customer side the heat market moves slowly, which makes it natural to treat the heat load as an external condition for the CHP-DHS.

The parameters supply temperature and return temperature in a DHS have been treated in Paper I and in the research project "Control strategies for district heating". Market solutions aimed at improving these parameters have been studied in some scientific projects, for example in "Samband mellan flödespremie och returtemperatur" [41]. This report shows that companies with a specific fee for district heating water flow on average have a $2.6^{\circ} \mathrm{C}$ lower supply water temperature and a $1.6^{\circ} \mathrm{C}$ lower return water temperature. 
Most CHP-DHSs have an accumulator, i.e. a storage tank for hot water, which helps to meet short peak loads in the DHS. This is practical for peak loads that are foreseeable, for example "the morning shower peak load". Short and foreseeable peak loads can therefore be handled without using any peak load HOBs.

Kensby et al. [42] describe how buildings in the district heating system have the potential to function as thermal short-term storage by periodically overheating and underheating the buildings. The company NODA uses a similar method to reduce peak loads and has succeeded in achieving a $20 \%$ power reduction by using a distributed software system that limits the output of heat (not hot water) for individual district heating substations [43].

\subsection{Inclusion of external effects - a system approach}

The most difficult, and perhaps the most important, aspect of a regional energy system analysis is the inclusion of external effects. The use of external effects is crucial to avoid the pitfalls of end-of-pipe solutions. If looking too narrowly at only the studied system then analytical mistakes are made. Two possible mistakes are missed consequences upstream and missed consequences downstream. A missed upstream consequence could be to overlook the depletion of a scarce resource, e.g. when use of an energy crop not only gives energy but also destroys the habitat for an endangered animal. A missed downstream consequence could be to not acknowledge the alternative service, e.g. the alternative heating solution for a house disconnected from a district heating network.

With a system approach, an attempt is made to describe the net effect of a system change. Hence, the analysis tries to include foreseeable changes in the surrounding environment. For example, if a power plant increases its use of wood it is a probable and foreseeable consequence that less wood is available in the fuel market. This consequence could be included in an analysis regarding fuel change for the power plant. However, the existence of a foreseeable consequence does not imply that it is easily quantified. Quantifying external effects is often a subject of debate. As mentioned earlier, in section 2.6.2., a calculation of the marginal electricity production is one example of how difficult it can be to quantify an external effect. Furthermore, this difficulty cannot be solved by simply removing it from the calculation, because arithmetically that is equal to giving it the very exact value of zero. In this way the quantification of external effects becomes a problem in itself. Without the inclusion of external effects, there is a tendency for simple end-of-pipe analysis. But with external effects, uncertainties and sensitivities can be overwhelming. 


\subsection{Energy conversion pathways}

This concluding section will summarise the other sections of the chapter and highlight an important question regarding energy systems. The question is a fundamental resource question: "Could this resource be used in a better way?".

We start with a simple fuel-energy flow, natural gas as fuel and heat as the desired energy service. The simplest use of this fuel resource is to burn it with an HOB (Heat Only Boiler). The efficiency of this process is approximately $80 \%$, comparing available heat and useful heat. Fig. 11 shows this fuel-energy pathway and four other possible pathways, all using the same fuel but different conversion technologies.
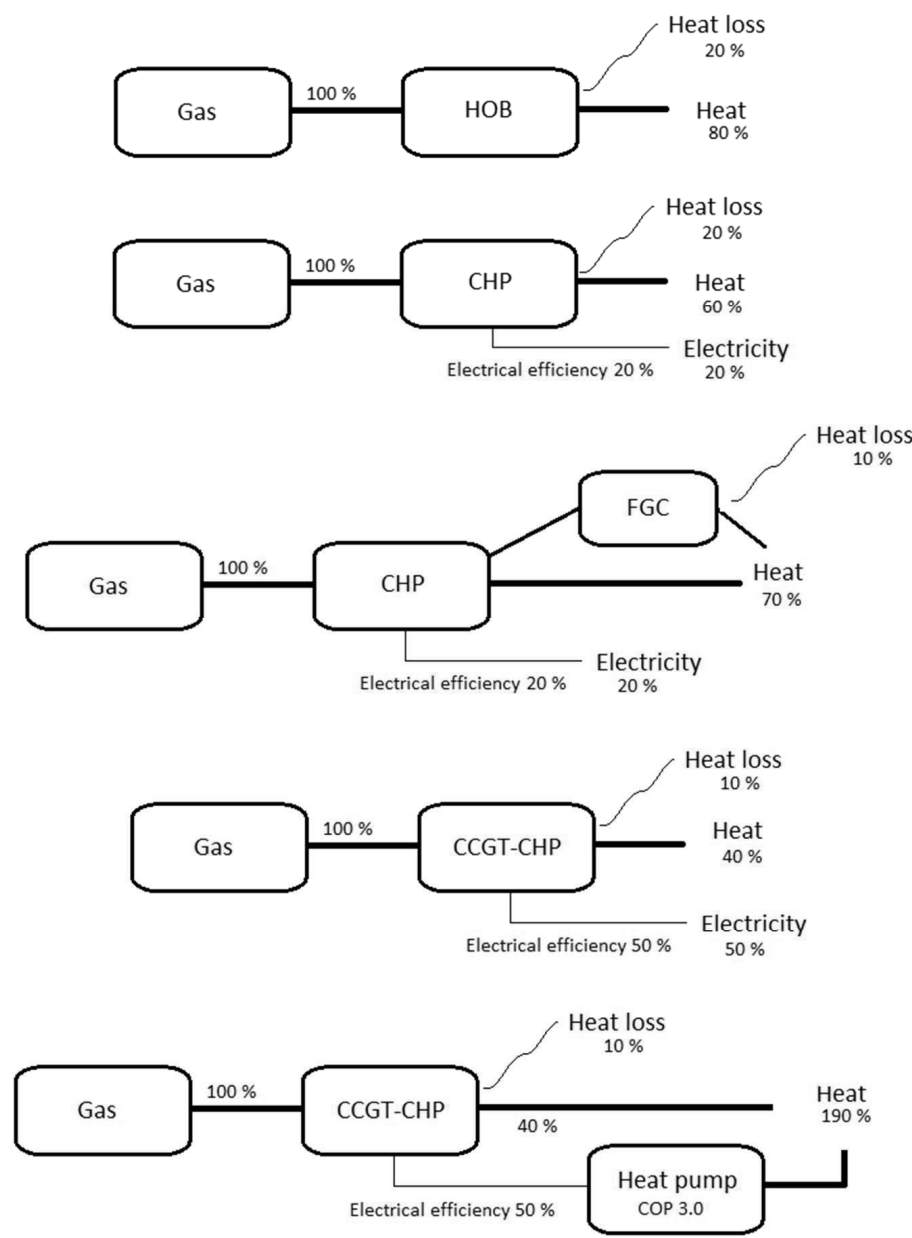

Figure 11. Illustration of different fuel-energy pathways for a natural gas fuel resource.

In the second pathway the fuel resource is also used in a boiler, but this time connected with a steam turbine and consequently transforming some of the energy into electricity. This is the basic CHP process and the heat loss remains at approximately $20 \%$ but the delivered quality of the energy service is now higher. In the third pathway the heat loss is reduced to $10 \%$ with 
help of an FGC (Flue Gas Condenser) absorbing some of the heat in the flue gas. In the fourth pathway the natural gas is being used in a CCGT (Combined Cycle Gas Turbine). This technology is more advanced but also more efficient, with approximately $50 \%$ electrical efficiency [10]. The fifth pathway illustrates how the fuel can be used if heating is the only desired energy service. The electricity produced in the CCGT can be used to power a heat pump and hence increase the delivered heat to $190 \%$ (100\% high grade heat transformed into $190 \%$ low grade heat).

In a Swiss study, Codina Girones et al. [44] show alternative fuel-energy pathways for wood, where they describe similar available pathways as described above but with differences in technology due to different fuel use (wood or natural gas). When wood is used, there is a need for a gasification step in order to use the CCGT technology. Biomass gasification in a Swedish context has been studied by, for example, Börjesson et al. [45]. They conclude that the most favourable conditions for CCGT-CHP technology are found in the largest DHSs in the country, due to economies of scale.

After a quick look at possible fuel-energy pathways for one fuel, we turn our attention to systems with several fuels. In these more complex energy systems, the usage of one fuel can affect the efficiency and/or usage of another fuel. The most common illustration of this is the peak power demand. A system that in base load circumstances is wood fired is often equipped with an oil-fired HOB that assists in covering peak power demand. Often the peak load unit has the lowest efficiency so when this unit is in operation the overall system efficiency goes down.

Another situation where several fuels are involved is when a co-combustion process is used. A low $\mathrm{CO}_{2}$-emitting fuel such as biomass can, for example, be co-fired with a high $\mathrm{CO}_{2}$ emitting fuel such as coal (see for example [46] or [47]), hence lowering the total $\mathrm{CO}_{2}$ emission intensity.

Sometimes one fuel-energy pathway can improve another fuel-energy pathway by means of system integration. This is often achieved by delivering waste heat from one process to another. In Paper II an example of system integration is studied. Fig. 12 shows the integrated system from Paper II, where the biogas fuel use is integrated with the regional CHP plant. 


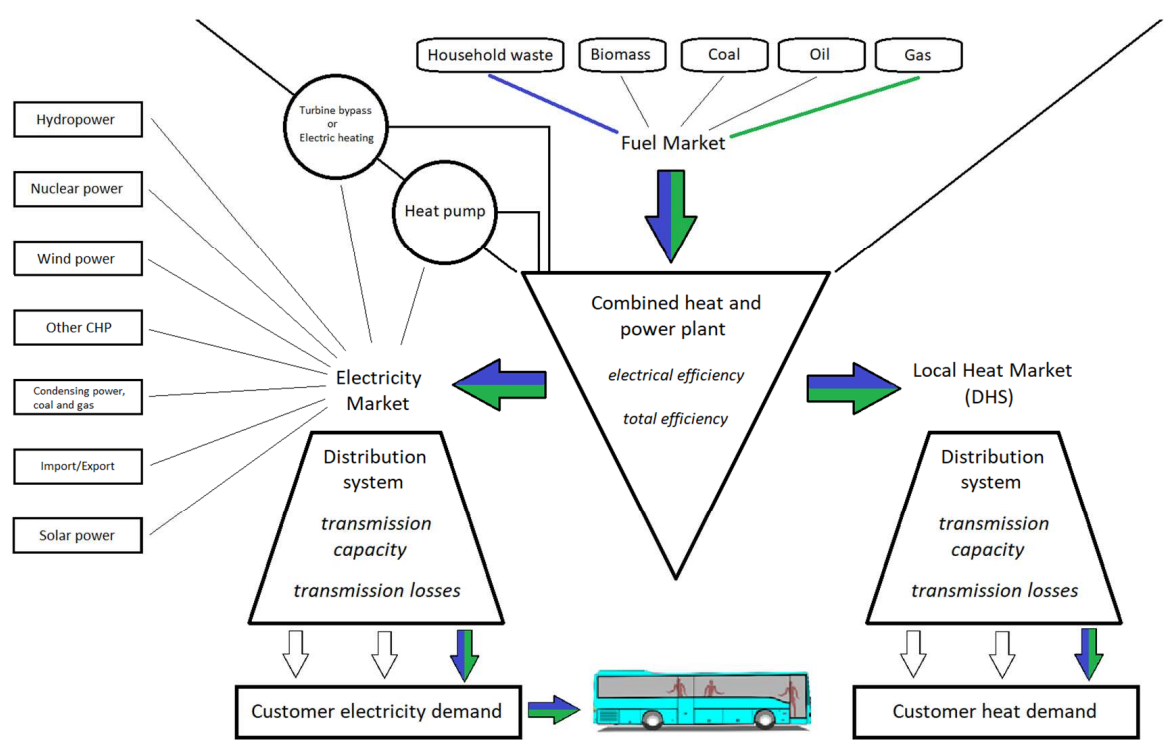

Figure 12. Schematic figure that illustrates how household waste and biogas flow through the regional energy system.

The use of biogas in the CHP plant also enables the plant to use the production unit with the highest electrical efficiency. This unit is a Combined Cycle Gas Turbine (CCGT) that both generates electricity by the expansion of the burning gas and transfers heat to a household waste powered steam turbine. This process coupling also elevates the electrical efficiency of the household waste turbine, giving a positive impact on the overall electrical efficiency.

A top-down analysis can be helpful in finding system inefficiencies that are caused by less optimal fuel-energy pathways. Some of these inefficiencies will not be acknowledged if technological systems are analysed one by one without a broader view. 


\section{Research design and methodology}

The general aim of the thesis is to present a top-down analysis of a regional energy system. With a modelling tool as help, different cases are described and evaluated regarding fuel use, efficiency and $\mathrm{CO}_{2}$-eq emissions. The goal is also to present "the big picture" of a regional energy system, which is the strength of the top-down method. The general approach is to perform a flow analysis covering fuel and energy flows in the studied system. In order to do that there is a need to collect parameter values for different technical components in the studied system.

The optimisation program MODEST is the mathematical tool used in this thesis. However, MODEST is not used for any advanced calculations; it is more of an administrative tool that is helpful in managing all the data concerning the energy flows. The most important aspect of the optimisation part is that it removes some of the personal bias of the researcher. For example, peak power demand is calculated in the exact same way in all examined cases, without interference from the researcher. The researcher is only involved in parametric input and analysis of the whole year energy system output. However, the personal bias of the researcher exists regarding which system modifications are included in the analysis. 


\subsection{Case studies}

This research is based on optimisation models of the regional energy system in Linköping municipality. Linköping is a municipality with about 150,000 inhabitants, situated in the southeast of Sweden. Tekniska verken AB is the regional power company and has a yearly production of $1500 \mathrm{GWh}$ heat and $260 \mathrm{GWh}$ electricity at two production sites. In the urban area of the municipality, DH is the dominant way of supplying heat to multi-family buildings, small houses, and commercial buildings. The base load in the DHS is covered by waste incineration at CHP plants. With the increasing load, other CHP plants are starting to burn other fuels such as wood, rubber, coal and oil. Heat only boilers are used to cover peak loads. The fuel merit order is as follows: waste, wood, coal/rubber and oil. In daily production, the heat load determines how much power is needed from the power plant boilers, and the electricity production in this system is a by-product. CHPs in this region normally operate in an electricity market with low prices, hence electricity production is not prioritised. Table 3 shows the three case studies in this thesis. The models serve as tools to compare different technological developing pathways.

Table 3. Case studies of Linköping municipality CHP-DHS using MODEST.

\begin{tabular}{|l|l|l|l|}
\hline & Case 1: A-E & Case 2: A-C & Case 3: A-B \\
\hline Model description & $\begin{array}{l}\text { Linköping } \\
\text { municipality CHP } \\
\text { and DHS with } \\
\text { supply/return water } \\
\text { temperature } \\
\text { dependent } \\
\text { components. } \\
\text { Components added } \\
\text { in research cases in } \\
\text { order to evaluate } \\
\text { different hardware } \\
\text { investments. }\end{array}$ & $\begin{array}{l}\text { Linköping } \\
\text { municipality CHP } \\
\text { and DHS with } \\
\text { supply/return water } \\
\text { temperature } \\
\text { dependent } \\
\text { components. }\end{array}$ & $\begin{array}{l}\text { Linköping } \\
\text { municipality CHP } \\
\text { and DHS. Regional } \\
\text { bus transport } \\
\text { described for two } \\
\text { alternative } \\
\text { technologies, electric } \\
\text { buses and biogas } \\
\text { driven ICE buses. }\end{array}$ \\
\hline Aim & $\begin{array}{l}\text { Scenario analysis of } \\
\text { five alternative } \\
\text { hardware } \\
\text { investments in the } \\
\text { CHP-DHS. }\end{array}$ & $\begin{array}{l}\text { Quantify overall } \\
\text { CHP-DHS efficiency } \\
\text { improvements if DH } \\
\text { supply and return } \\
\text { temperatures are } \\
\text { lowered. }\end{array}$ & $\begin{array}{l}\text { Quantify the } \\
\text { difference in overall } \\
\text { CHP-DHS efficiency } \\
\text { between two } \\
\text { alternative fuel } \\
\text { pathways for the } \\
\text { regionally produced } \\
\text { biogas. }\end{array}$ \\
\hline Number of cases & 2 & $\begin{array}{l}\text { Control strategies for } \\
\text { district heating }\end{array}$ & Paper I \\
\hline Research publication
\end{tabular}




\subsubsection{Models}

Three models have been developed to perform the case studies presented in section 3.1. In this section the model from Paper I is presented in detail.

In this study, the optimisation software Model for Optimisation of Dynamic Energy Systems with Time-dependent components and boundary conditions (MODEST) was used (see section 2.1.1). The DHS system was represented in the model by four different kinds of nodes - fuel nodes, conversion nodes (boilers, turbines, and flue gas condensers), demand nodes (traditional heat customers and low-grade heat customers), and waste nodes (electricity production and heat losses). The power plants were described in terms of the efficiencies, maximum capacity, temperature-dependent power-to-heat ratio, and temperature-dependent flue gas condenser efficiency. The heat load profile was taken from measurements from 2015. The MODEST model is described in detail by Henning [19]. Several authors have used MODEST to analyse DHS, for example Lidberg et al. [20] and Gebremedhin [21]. MODEST is a top-down tool that can be used to represent the largest flows in an energy system. The optimisation objective was to minimise the annual system cost while satisfying a given heat load demand. The fuel costs were fixed during the examined year and were mainly set to force the model optimisation algorithm to choose plants in the correct merit order. Details of the model are shown in Tables 4-7 and Figures 13-18.

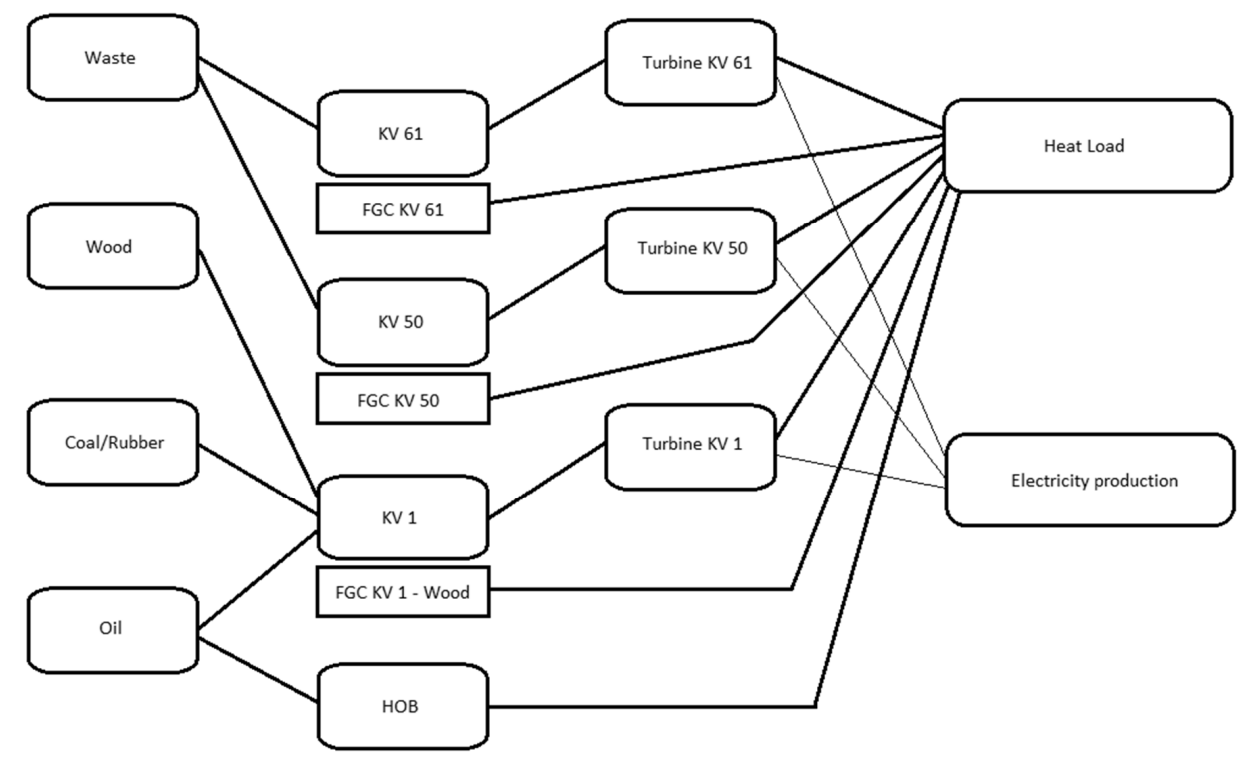

Figure 13. Illustration of nodes and flows in the model from Paper I. 
Table 4. Production units in Linköping CHP-DHS.

\begin{tabular}{|l|l|l|l|l|}
\hline Power Plant & $\begin{array}{l}\text { Maximum } \\
\text { Output (MW } \\
\text { Thermal Power) }\end{array}$ & Fuel & $\begin{array}{l}\text { Flue Gas } \\
\text { Condenser } \\
\text { Efficiency (\% } \\
\text { of Boiler } \\
\text { Power) }\end{array}$ & $\begin{array}{l}\text { Steam Turbine } \\
\text { Efficiency } \\
\text { (Electricity } \\
\text { Production/Input } \\
\text { Heat) }\end{array}$ \\
\hline KV 50 & 72 & $\begin{array}{l}\text { Household } \\
\text { waste }\end{array}$ & $15-40$ & $0.10-0.15$ \\
\hline KV 61 & 66 & $\begin{array}{l}\text { Household } \\
\text { waste }\end{array}$ & $0-22$ & $0.17-0.27$ \\
\hline KV 1 - wood & 60 & Wood & 20-40 & $0.18-0.26$ \\
\hline KV 1 - coal & 60 & Coal/Rubber & $\begin{array}{l}\text { FGC not } \\
\text { available }\end{array}$ & $0.18-0.26$ \\
\hline KV 1 - oil & 120 & Oil & $\begin{array}{l}\text { FGC not } \\
\text { available }\end{array}$ & $0.18-0.26$ \\
\hline $\begin{array}{l}\text { HOBs (Heat } \\
\text { Only Boilers, } \\
\text { several } \\
\text { distributed in } \\
\text { DH network) }\end{array}$ & 240 & Oil & $\begin{array}{l}\text { FGC not } \\
\text { available }\end{array}$ & No turbine \\
\hline
\end{tabular}

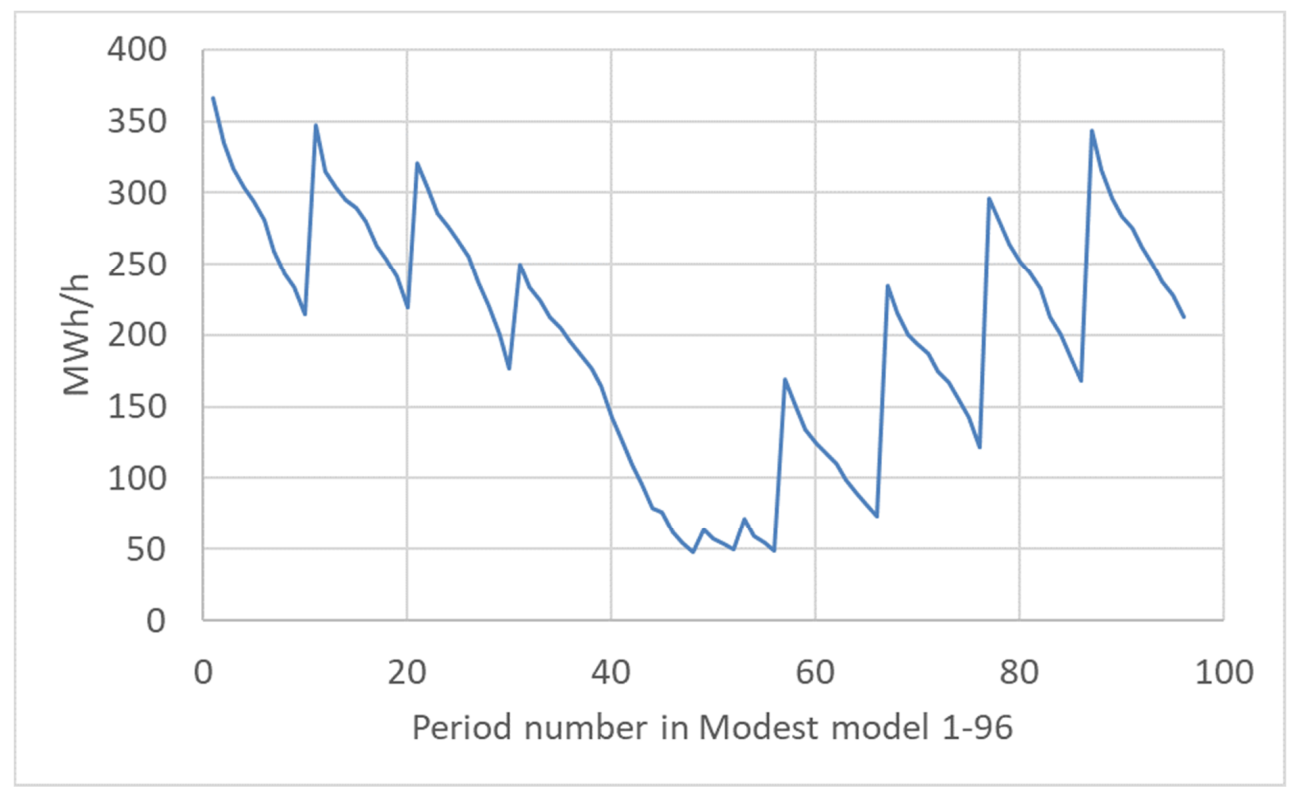

Figure 14. Heat load in the model, presented with monthly duration diagram (i.e. days sorted by heat load in each month). Days with higher heat loads are modelled in greater detail. 
Table 5. Fuel prices in the model.

\begin{tabular}{|l|l|}
\hline Fuel & Price in Model \\
\hline Waste & 0 SEK/MWh \\
\hline Wood & $70 \mathrm{SEK} / \mathrm{MWh}$ \\
\hline Coal/Rubber & $180 \mathrm{SEK} / \mathrm{MWh}$ \\
\hline Oil CHP & $320 \mathrm{SEK} / \mathrm{MWh}$ \\
\hline Oil HOB & $600 \mathrm{SEK} / \mathrm{MWh}$ \\
\hline
\end{tabular}

Table 6. Time division in the model.

\begin{tabular}{|l|l|}
\hline Period & Time Resolution \\
\hline $\begin{array}{l}\text { January-April (first 10 days in monthly duration } \\
\text { diagram) }\end{array}$ & $\begin{array}{l}\text { Average heat load for } 48 \mathrm{~h} \\
\text { periods }\end{array}$ \\
\hline $\begin{array}{l}\text { January-April (remaining days in monthly duration } \\
\text { diagram) }\end{array}$ & $\begin{array}{l}\text { Average heat load for } 96 \mathrm{~h} \\
\text { periods }\end{array}$ \\
\hline May-August & Average heat load for each week \\
\hline $\begin{array}{l}\text { September-December (first 10 days in monthly duration } \\
\text { diagram) }\end{array}$ & $\begin{array}{l}\text { Average heat load for } 48 \mathrm{~h} \\
\text { periods }\end{array}$ \\
\hline $\begin{array}{l}\text { September-December (remaining days in monthly } \\
\text { duration diagram) }\end{array}$ & $\begin{array}{l}\text { Average heat load for } 96 \mathrm{~h} \\
\text { periods }\end{array}$ \\
\hline
\end{tabular}

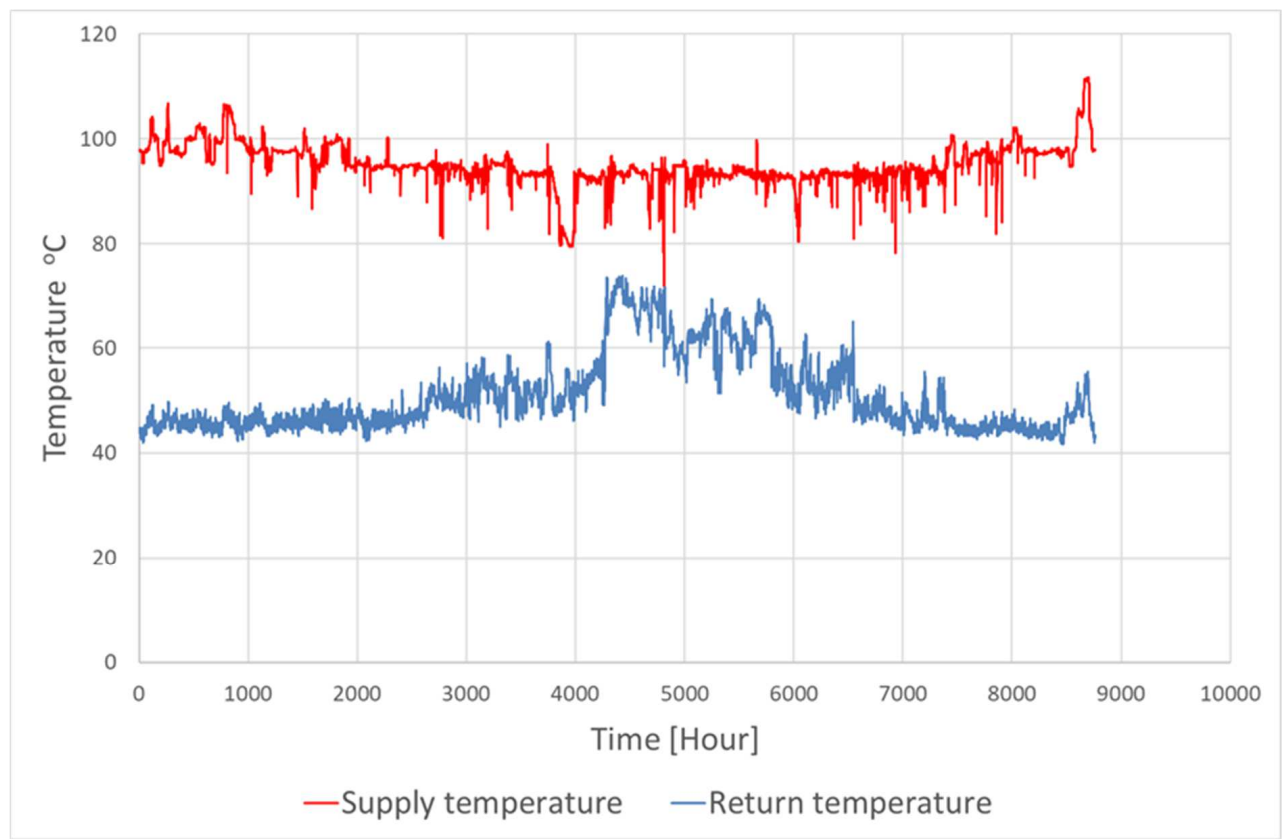

Figure 15. Measured supply and return temperatures in Linköping's DHS in 2015. 


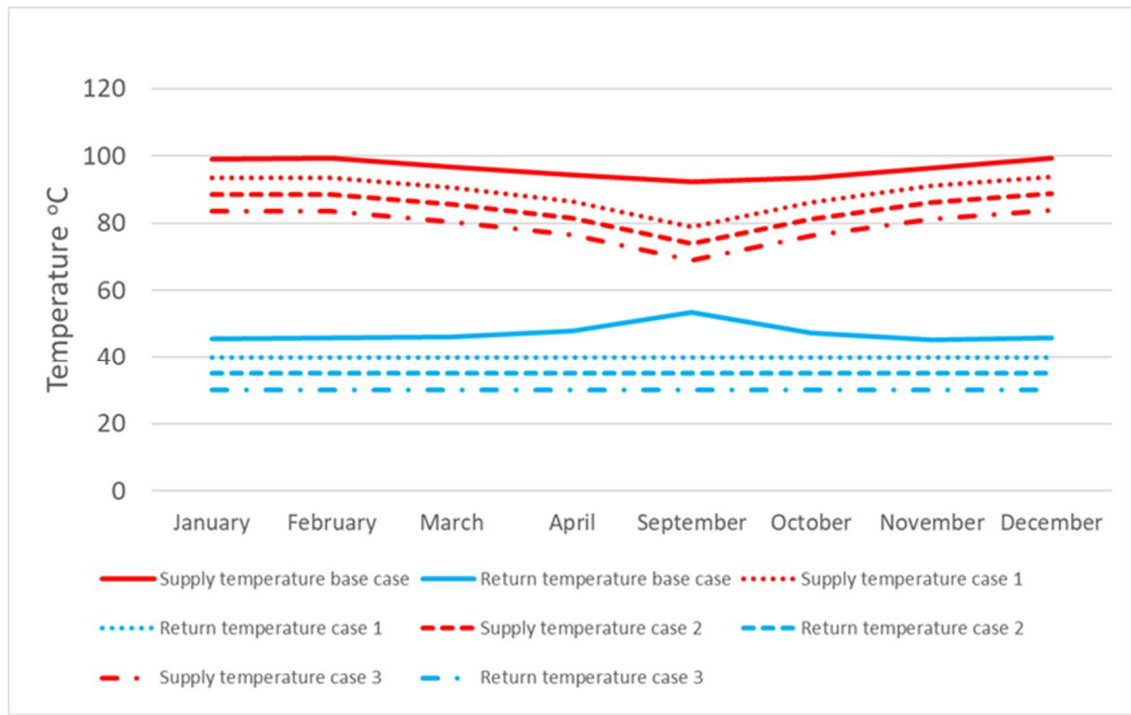

Figure 16. System temperatures in the Paper I MODEST model. Temperatures for the base case and three cases with lowered temperatures.

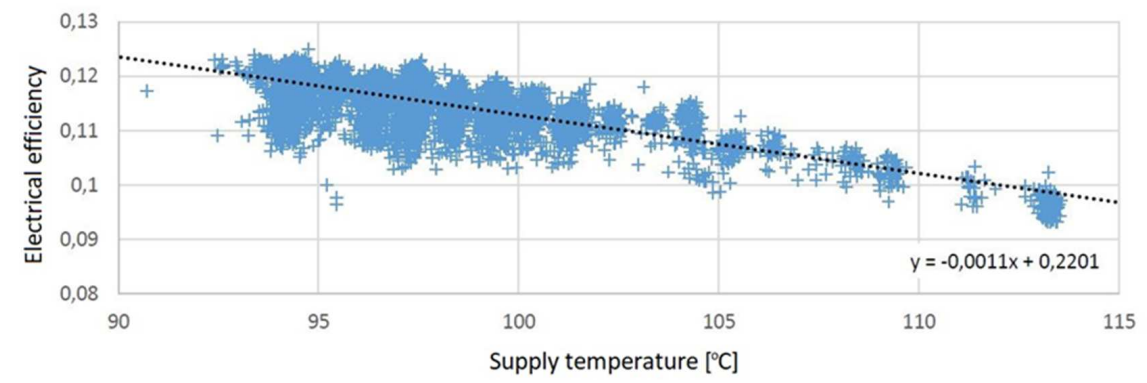

Figure 17. Measured efficiencies for KV50 turbine - waste incineration plant. 


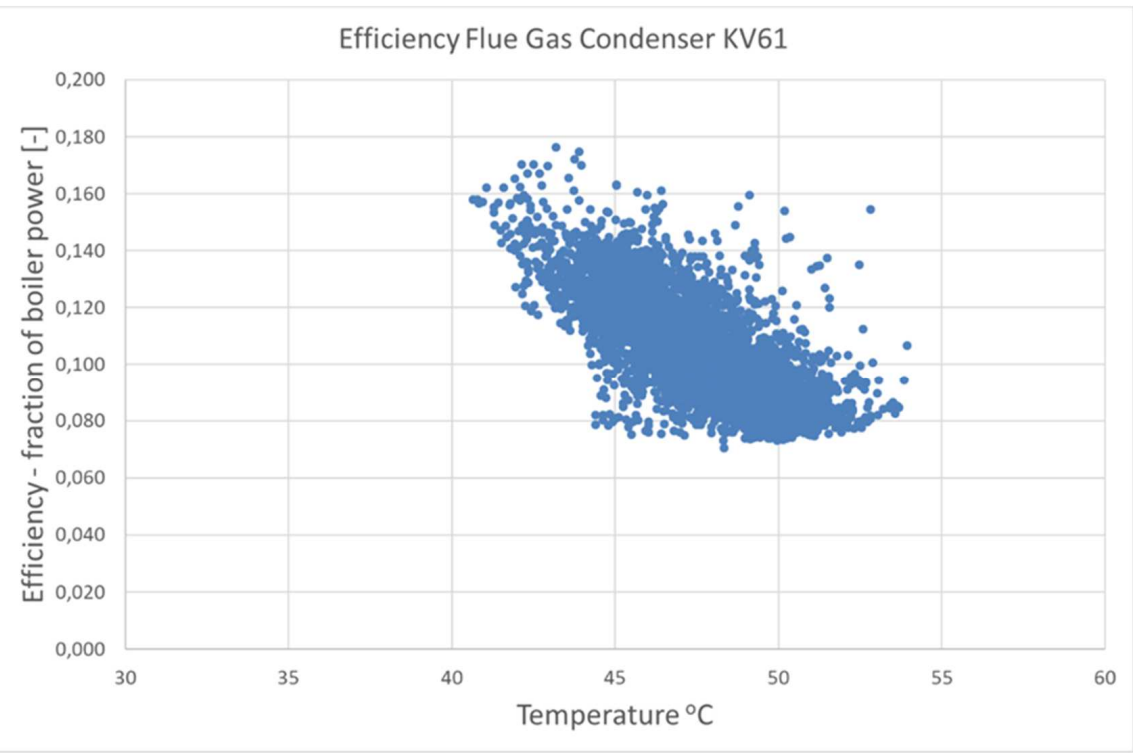

Figure 18. Flue gas condenser efficiency for KV 61 waste incineration unit. Samples have been collected over several years and during different operation modes. There are variations in boiler power, fuel moisture, outdoor pressure, and so on. This gives a considerable data dispersion, but the temperature trend is clear.

Table 7. Temperature-dependent efficiencies in the MODEST model ( $Y=$ efficiency as fraction of boiler power; $X=$ temperature $\left[{ }^{\circ} \mathrm{C}\right]$ ).

\begin{tabular}{|l|l|}
\hline Power Plant Component & $\begin{array}{l}\text { Efficiency Equation, Fraction of Boiler } \\
\text { Power }\end{array}$ \\
\hline Turbine KV 1 & $\mathrm{Y}=-0.0015 * \mathrm{X}+0.3907$ \\
\hline Turbine KV 50 & $\mathrm{Y}=-0.0011 * \mathrm{X}+0.2201$ \\
\hline Turbine KV 61 & $\mathrm{Y}=-0.0019 * \mathrm{X}+0.3938$ \\
\hline Flue gas condenser KV 1 - wood & $\mathrm{Y}=-0.0064 * \mathrm{X}+0.5557$ \\
\hline Flue gas condenser KV 50 - waste & $\mathrm{Y}=-0.0069 * \mathrm{X}+0.54$ \\
\hline Flue gas condenser KV 61 - waste & $\mathrm{Y}=-0.0061 * \mathrm{X}+0.394$ \\
\hline
\end{tabular}

\subsubsection{Example of a chain of intensity factors in the model from Paper I}

For each time step the optimisation model chooses which plants to operate to cover the present heat load with the lowest fuel cost. We can study one time-step in detail to illustrate how the model works. At the first time-step in March (period 21, Figure 13) the heat load intensity is $320 \mathrm{MWh} / \mathrm{h}$. To cover that heat load all power plants except the HOB have to be in operation. If we examine the second case from the Paper I model then the supply temperature is $85^{\circ} \mathrm{C}$ and the return temperature is $35^{\circ} \mathrm{C}$ (Figure 15). The $\mathrm{KV} 61$ plant is in full power operation. With a return water temperature of $35^{\circ} \mathrm{C}$ the KV $61 \mathrm{FGC}$ has an efficiency of $18.05 \%$ (Table 7), meaning that the FGC delivers $0.1805 * 66=11.91 \mathrm{MW}$ heat to the DHS. With a supply water temperature of $85^{\circ} \mathrm{C}$ the KV 61 turbine has an electrical efficiency of $23.23 \%$ (Table 7), meaning that the turbine delivers $0.2323 * 66=15.33 \mathrm{MW}$ to the electricity grid and $50.66 \mathrm{MW}$ heat to the DHS. There is also a general heat loss of $15 \%$ so at the studied time-step the KV 61 plant delivers $15.33 \mathrm{MW}$ electricity and $62.57 \mathrm{MW}$ heat from 77.64 MW of fuel. 


\section{Results and Discussion}

In this section results from the three case studies are presented. First the results from "Control strategies for district heating" are presented, then the results from the studies of Paper I and Paper II, respectively. Sections 4.4-4.5 contain a methodological critique and a discussion about how an analytical top-down method could be used for greenwashing, i.e. used in a way that creates results with deceptively shaped information that gives an impression of lower emissions or a "greener" appearance. Finally, in section 4.6, the best fuel-energy pathways in a regional energy system are discussed.

\subsection{Case study results - Case 1 : A-E}

In the research project "Control strategies for district heating" six different technological development pathways for Linköping municipality CHP-DHS were examined. Five cases, Cases A-E, are described in Table 8. All cases are compared to a base case which is the model describing today's CHP-DHS.

Table 8. Examined cases in the research project "Control strategies for district heating".

\begin{tabular}{|l|l|}
\hline Case & Case description \\
\hline Base Case & Today's CHP-DHS, reference case. \\
\hline Case A & $\begin{array}{l}\text { Low temperature DH, the heat load in DHS is modified so supply and } \\
\text { return water temperatures are lowered. Efficiencies for FGC and turbines } \\
\text { are improved. (This scenario is described in detail in Paper I) }\end{array}$ \\
\hline Case B & $\begin{array}{l}\text { High electrical efficiency. The model describes a CHP plant where } \\
\text { hardware investments have been implemented in order to achieve "best } \\
\text { practice" for waste incineration plants. }\end{array}$ \\
\hline Case C & $\begin{array}{l}\text { A combination of Case A and Case B, both high electrical efficiency and } \\
\text { lowered system temperatures. }\end{array}$ \\
\hline Case D & $\begin{array}{l}\text { High electrical efficiency, combined with heat pumps in order to minimise } \\
\text { fuel use without reducing electricity production. }\end{array}$ \\
\hline Case E & $\begin{array}{l}\text { Turbine bypass. Full priority to heat production and no electricity } \\
\text { production. }\end{array}$ \\
\hline
\end{tabular}

\subsubsection{Energy flows}

The different system modifications that are modelled in Cases A-E affect which production units are used to deliver the DH heat load. Table 9 presents model results. For each case fuel use, FGC production and electricity production are presented. The accumulated heat load is the same in all cases: $1459 \mathrm{GWh}$ for one year. 
Table 9. Production and fuel use for the modelled cases. All values in GWh.

\begin{tabular}{|c|c|c|c|c|c|c|c|c|}
\hline Model & $\begin{array}{l}\text { Electricity } \\
\text { production }\end{array}$ & FGC-wood & FGC-KV50 & FGC-KV61 & Wood fuel & Coal/Rubber fuel & Oil & Waste \\
\hline Base Case & 276 & 69 & 123 & 40 & 333 & 212 & 122 & 1137 \\
\hline $\begin{array}{l}\text { Case A - low } \\
\text { temperature DH }\end{array}$ & 283 & 88 & 173 & 75 & 304 & 170 & 85 & 1124 \\
\hline \begin{tabular}{|l|} 
Case B - high \\
electrical efficiency
\end{tabular} & 513 & 76 & 128 & 43 & 368 & 272 & 245 & 1195 \\
\hline \begin{tabular}{|l|} 
Case $\mathrm{C}$ - high \\
electrical efficiency \\
and low \\
temperature DH
\end{tabular} & 470 & 97 & 177 & 79 & 337 & 223 & 154 & 1180 \\
\hline $\begin{array}{l}\text { Case D - high } \\
\text { electrical efficiency } \\
\text { and heat pumps }\end{array}$ & 343 & 69 & 128 & 39 & 333 & 142 & 80 & 1137 \\
\hline $\begin{array}{l}\text { Case } \mathrm{E} \text { - turbine } \\
\text { bypass, only heat } \\
\text { production }\end{array}$ & 0 & 56 & 121 & 39 & 270 & 99 & 17 & 1096 \\
\hline
\end{tabular}

In order to give a better overview of the results, they are also presented as relative changes compared to the base case. In Fig. 19 changes are shown grouped by case and in Fig. 20 changes are shown grouped by sub-system. The figures thus present the same original data but in different presentation formats. 


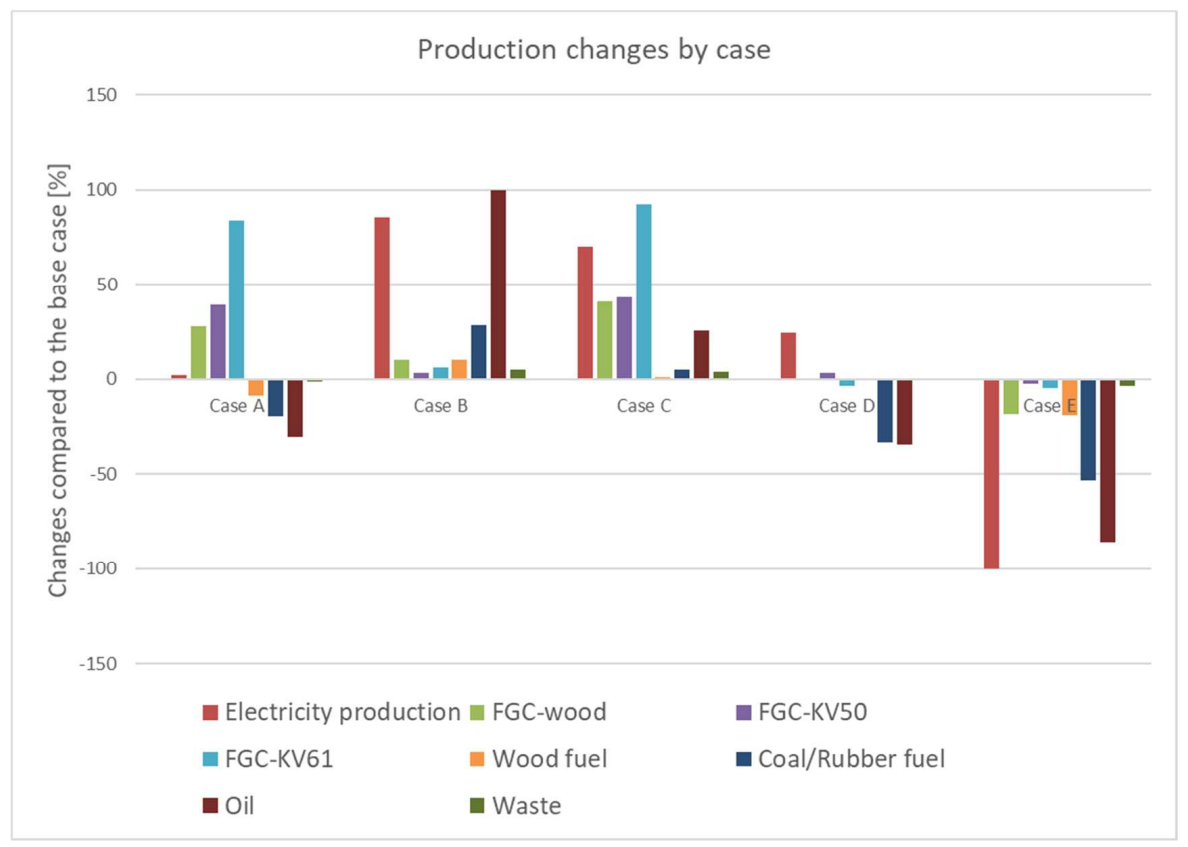

Figure 19. Linköping municipality CHP-DHS. Modelled changes compared to the base case for Cases A-E.

\section{Case A:}

Low temperature $\mathrm{DH}$, the lowered return water temperature achieves reduced fuel use for oil, coal/rubber and wood. The largest reduction is for oil, which is reduced by approximately 30 $\%$. The fuel use is reduced due to higher efficiency in the FGCs, where FGC-KV61 shows an $80 \%$ increase in heat delivery.

\section{Case B:}

The higher electrical efficiency in Case B gives a general increase in fuel use. Electricity production is increased by about $85 \%$ and the peak load fuels oil and coal/rubber are increased.

\section{Case C:}

Case $\mathrm{C}$ is a combination of Case $\mathrm{A}$ and Case $\mathrm{B}$ and has a $70 \%$ increase in electricity production. There is a large increase in heat deliverance from FGCs. The peak load fuel oil is increased by about $25 \%$.

\section{Case D:}

In this case the electricity production is increased by about $20 \%$ and the fuel use is reduced for all fuels. The peak load fuels oil and coal/rubber have the largest reduction, at about $30 \%$.

\section{Case E:}

With turbine bypass there is naturally a $100 \%$ reduction in electricity production. With only heat production the peak load fuels are reduced by $50 \%$ and $85 \%$ respectively. 


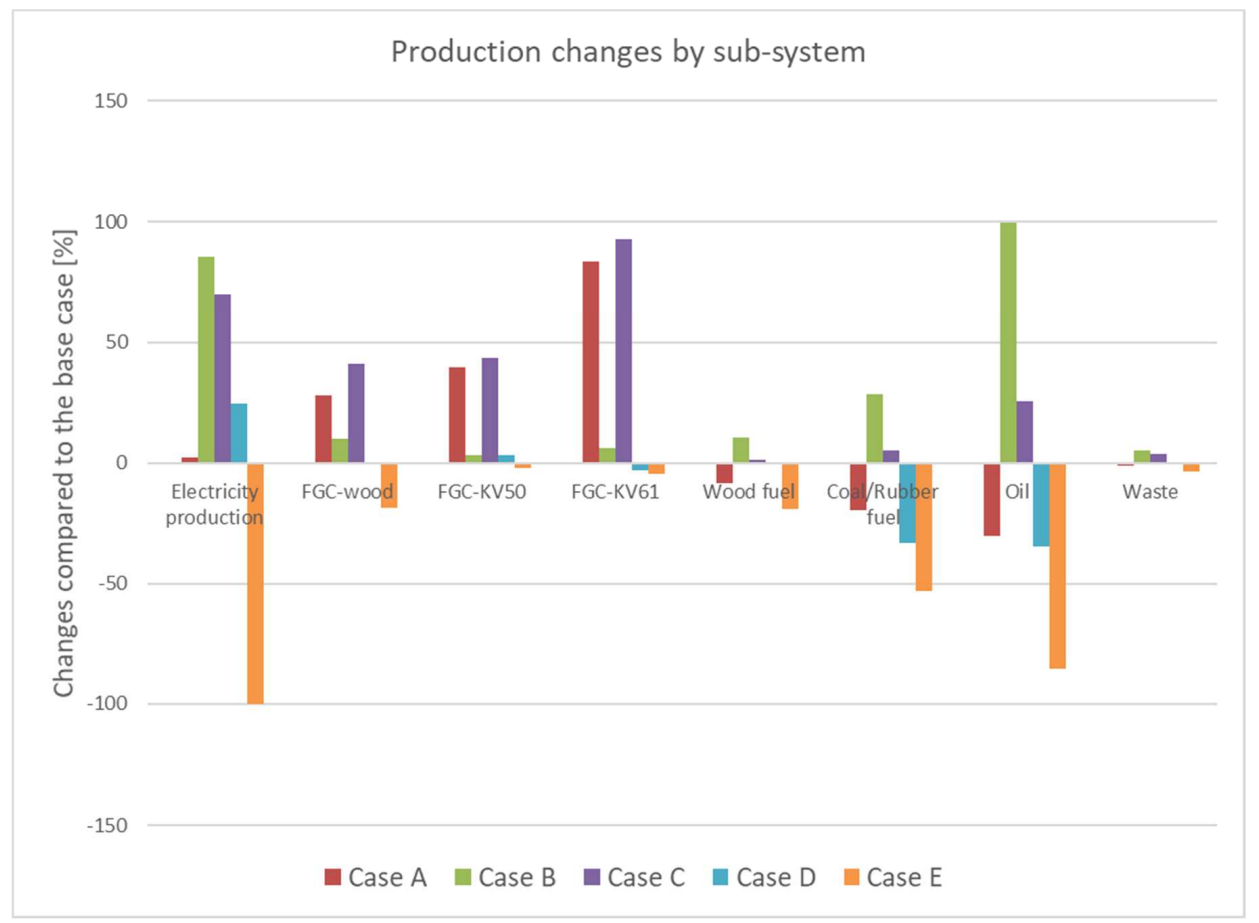

Figure 20. Linköping municipality CHP-DHS. Modelled changes compared to the base case for Cases A-E.

Electricity production varies considerably between the cases. Case A - low temperature DH, has a small increase in electricity production due to more beneficial system temperatures. The difference between Case B and Case $\mathrm{C}$ shows that there is a competition between electricity production and high efficiency for FGCs. FGCs operating with high efficiency will reduce electricity production. However, effective FGC operation gives better fuel economy.

FGCs have considerably higher heat production in the cases with lower return water temperature, i.e. Case A and Case C.

Wood is second in the fuel merit order and is therefore not so much affected by the system changes. The greatest change is in Case E - turbine bypass, where the use of wood is reduced by about $20 \%$.

The peak load fuels oil and coal/rubber have large differences between cases. In relation to the base case, oil use varies between $+100 \%$ and $-85 \%$ for Case B and Case E.

Waste incineration is first in the fuel merit order due to the low fuel price. Consequently, waste incineration is least affected by different system modifications because the fuel is used in base load production. 


\subsubsection{CO2-eq emissions}

The emission values in Table 10 are derived from The Environmental Fact Book [48]. Coal condensing power (CCP) was used as the marginal production unit in the European electricity market, and the turbine efficiency for these plants was considered to be $40 \%$. To evaluate the impact of the saved fuel, the assumption was made that the saved fuel is used in CCP to replace the coal (see, for example, [46, 47].

Table 10. Emissions of greenhouse gas (GHG) CO2-eq for each fuel, The Environmental Fact Book [48].

\begin{tabular}{|l|l|}
\hline Fuel & $\begin{array}{l}\text { Emissions [kg CO} \\
\text { eq/MWh] }\end{array}$ \\
\hline Wood & 14 \\
\hline Oil & 288 \\
\hline Coal/Rubber & 360 \\
\hline Waste & 136 \\
\hline Coal & 388 \\
\hline
\end{tabular}

Fig. 21 shows $\mathrm{CO}_{2}$-eq emissions for the studied cases. Emissions are presented with three different evaluation methods.

1) Local emissions.

2) Emissions with the assumption that coal condensing power is the marginal electricity producer in the European electricity market.

3) Emissions with the assumption that coal condensing power is the marginal electricity producer in the European electricity market and the assumption that saved fuel replaces coal in the fuel market (co-combustion).

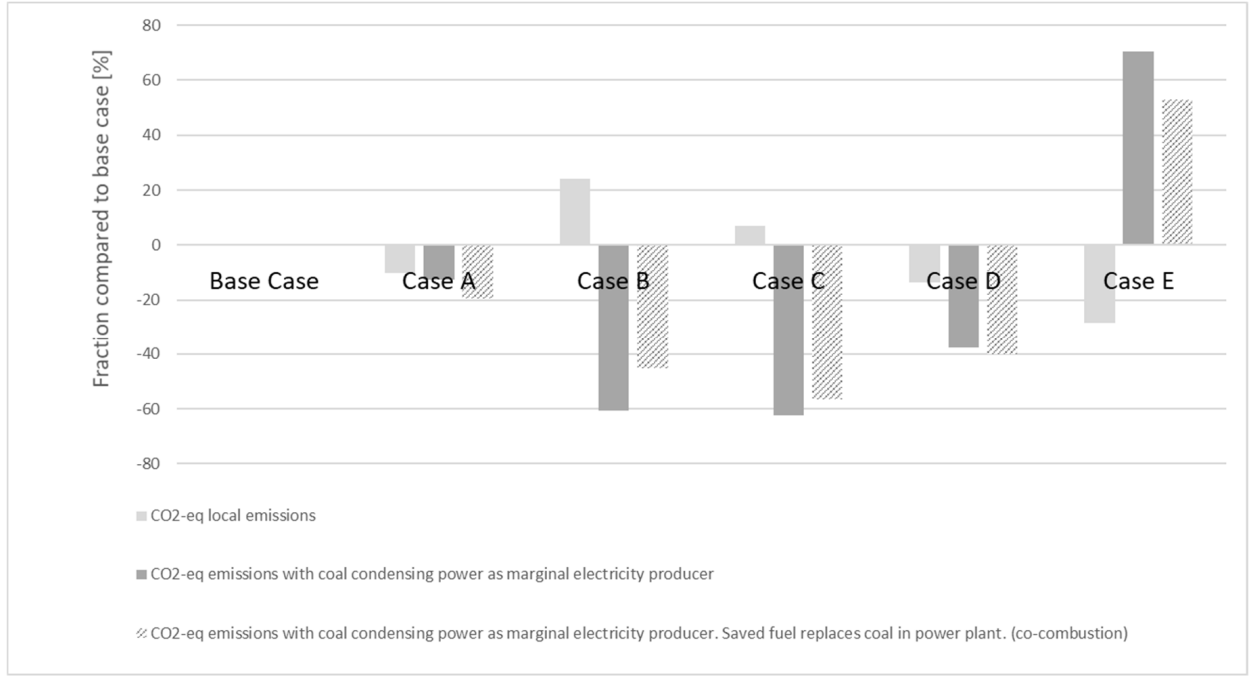

Figure 21. Modelled changes in GHG emissions for the examined cases with three different system boundaries. 


\section{Case A:}

Low temperature DH: the lowered return water temperature achieves reduced emissions regardless of evaluation method. With market effects on both the electricity market and the fuel market, emissions are modelled to be reduced by approximately $20 \%$.

\section{Case B and Case E:}

These two cases are almost each other's opposites. In Case B the electricity production is increased, almost doubled, and in Case $\mathrm{E}$ the electricity production is decommissioned. For these two cases the choice of $\mathrm{CO}_{2}$ valuation method is critical. A local view, without market effects, will favour Case E - turbine bypass, but with market effects then Case B will be favourable. The important dynamics for these cases are clearly outside the regional system, with the most important issue being the electricity import/export relationship between the regional energy system and its surroundings. This raises an important question for the regional power company: Should we manage the system to reduce local emissions or global emissions?

\section{Case C:}

Case $\mathrm{C}$ is a combination of Case A and Case B and it has a $70 \%$ increase in electricity production. With better fuel economy, due to the lower supply/return water temperature, the increase in local emissions is lower than for Case B. However, the conflict between the local and global view is still present.

\section{Case D:}

The developing pathway that is described by the Case D model can be considered to be "the safe bet" regarding $\mathrm{CO}_{2}$ emissions. Investments in both better turbines and in heat pumps will reduce $\mathrm{CO}_{2}$ emissions - this statement is supported by all three valuation methods. Hence, the $\mathrm{CO}_{2}$ reduction for this case is not dependent on assumed market effects.

\subsection{Case study results - Case $2: A-C$}

Paper I explores how supply water temperature and return water temperature affect the efficiencies of different CHP components. A case study was performed for the CHP-DHS in Linköping municipality. Table 11 describes the examined cases.

Table 11. Examined cases in Paper I.

\begin{tabular}{|l|l|}
\hline Case & Case description \\
\hline Base Case & $\begin{array}{l}\text { Today's CHP-DHS, reference case. Efficiencies for turbines and FGC } \\
\text { corresponding to temperature measurements from } 2015 .\end{array}$ \\
\hline Case A & $\begin{array}{l}\text { Low-grade heat customers with sufficient heat load to control return water } \\
\text { temperature to } 40^{\circ} \mathrm{C} \text {. }\end{array}$ \\
\hline Case B & $\begin{array}{l}\text { Low-grade heat customers with sufficient heat load to control return water } \\
\text { temperature to } 35^{\circ} \mathrm{C} \text {. }\end{array}$ \\
\hline Case C & $\begin{array}{l}\text { Low-grade heat customers with sufficient heat load to control return water } \\
\text { temperature to } 30^{\circ} \mathrm{C} .\end{array}$ \\
\hline
\end{tabular}




\subsubsection{Energy flows}

The system modifications that are modelled in Cases A-C affect which production units are used to deliver the DH heat load. In Fig. 22 whole year efficiencies for sub-system components are shown.

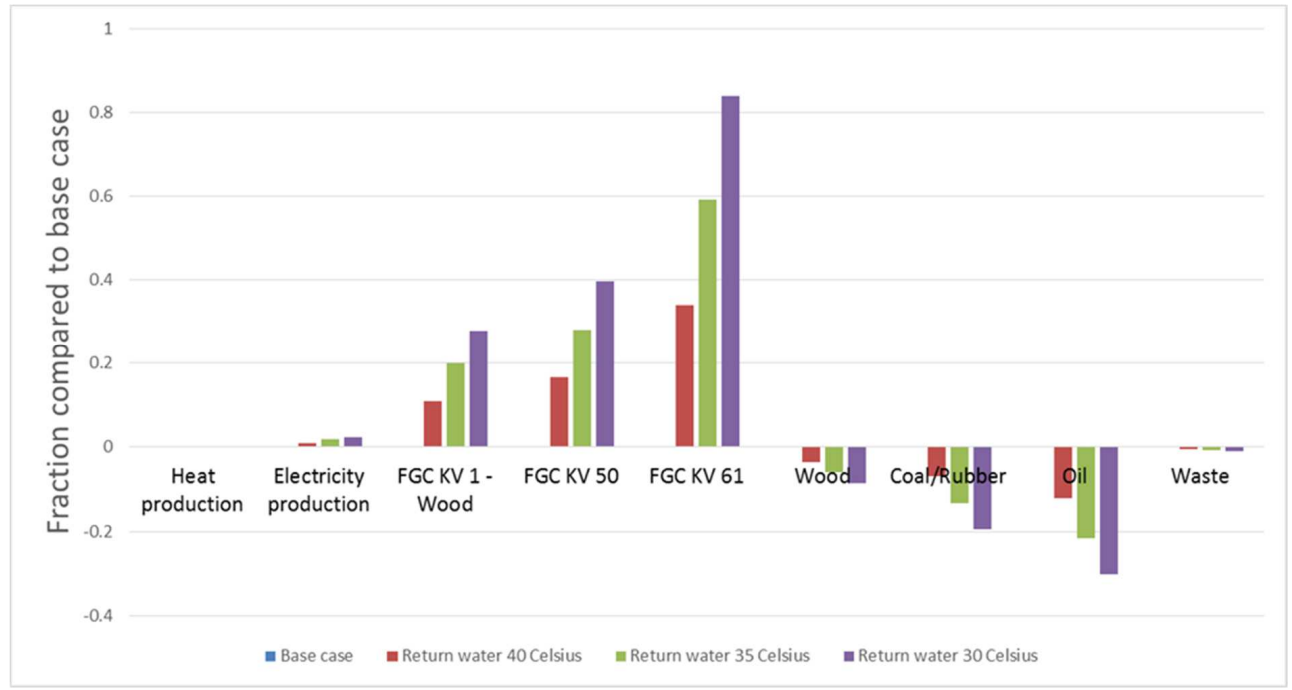

Figure 22. Modelled changes in whole year efficiencies and fuel consumption.

Heat production is a boundary condition in the model, so naturally this will not differ between the base case and the three cases with controlled return water temperature. For fuel consumption, waste fuel is almost unchanged for all the cases. Oil use has the largest reduction, with $30 \%$ for Case $\mathrm{C}$. FGC heat is almost doubled, with an $84 \%$ increase for KV61 corresponding to $35 \mathrm{GWh}$ of free heat, which, in the base case, is lost with the flue gas. For Case C, the total increase in FGC heat is $103 \mathrm{GWh}$, corresponding to around $7 \%$ of the total DHS heat.

\subsection{2. $\mathrm{CO}_{2}$-eq emissions}

In Paper I three different sets of emission data were presented for Cases A-C, here shown in Fig. 23. In an effort to include the market effects caused by the change in local electricity production for the studied CHP-DHS, marginal electricity production and marginal fuel consumption were added in evaluation methods 2 and 3. Method 2 only included market effects in the electricity market, while method 3 included both the electricity market and the fuel market. In Paper I coal condensing power was chosen as the marginal electricity producer, in order to show two extremes in which increased electricity production can be valued. Accounting for only local emissions is one way, giving no value to changes in electricity production. Accounting for avoided emissions from the most polluting source, coal condensing power, is another way. Olkkonen et al. [49] present calculations regarding the marginal electricity production for the Finnish, Nordic and European energy systems, up until 2030. Their calculations indicate that during the winter season, coal condensing power has the largest share between the different marginal generation technologies. 
1. Local emissions.

2. Emissions with the assumption that coal condensing power is the marginal electricity producer in the European electricity market.

3. Emissions with the assumption that coal condensing power is the marginal electricity producer in the European electricity market and the assumption that saved fuel replaces coal in the fuel market (co-combustion).

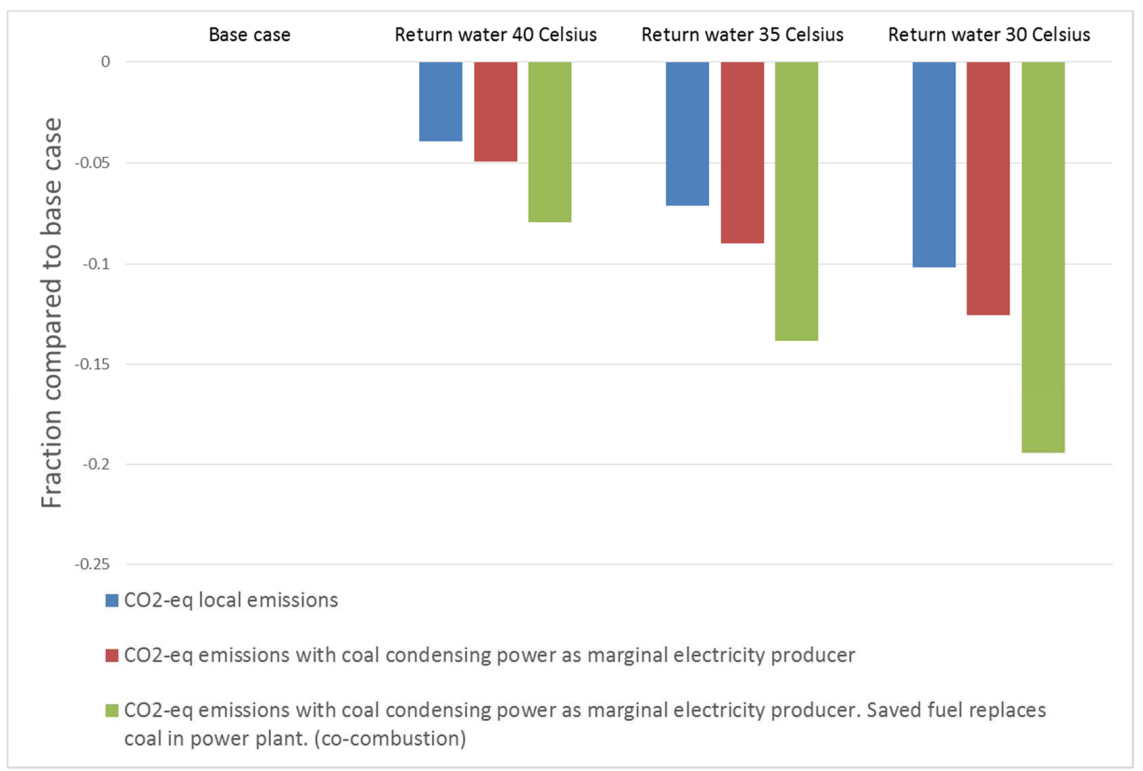

Figure 23. Modelled changes in GHG emissions for the examined cases with three different system boundaries.

Changes in GHG emissions for the three different evaluation methods are almost linear with the return water temperature. This is a natural consequence of the underlying linear equation for FGC and turbine efficiencies in the model. The temperature trend is clear for all the cases, but the choice of evaluation method has a strong impact on the absolute emission values. Case $\mathrm{C}$, evaluated with the third emission evaluation category, showed a reduction of almost $20 \%$ in GHG emissions. The third evaluation method gives value to general fuel savings because all saved fuel is assumed to replace coal in coal power plants (co-combustion, see for example [47]). Without this evaluation method, wood fuel savings are almost not valued at all. 


\subsection{Case study results - Case 3: A-B}

Paper II explores a future situation where the biogas energy flow is changed from today's use in biogas driven buses to being used in the CCGT in the CHP-DHS. Table 12 describes the two examined cases.

Table 12. Examined cases in Paper II.

\begin{tabular}{|l|l|}
\hline Case & Description \\
\hline Case A & $\begin{array}{l}\text { Model of the current system. The local transport service provided } \\
\text { by } 65 \text { biogas driven buses. CHP and DHS provide power and heat } \\
\text { to the region. }\end{array}$ \\
\hline Case B & $\begin{array}{l}\text { Model of an integrated system. Biogas is used in CCGT which is } \\
\text { integrated in the CHP and DHS. The local transport service is } \\
\text { provided by electric buses. }\end{array}$ \\
\hline
\end{tabular}

\subsubsection{Energy flows}

Table 13 presents model results for one whole year. The accumulated heat load is the same in both cases: $1459 \mathrm{GWh}$ for one year. The transport service is also the same for both cases: 5.3 million $\mathrm{km}$ of transport service. The change in biogas flow triggers other system changes affecting fuel use in the CHP-DHS. Due to increased system efficiency and reduced heat losses, all other fuels are used less in Case B than in Case A.

Table 13. Whole year values for Case A and Case B in Paper II.

\begin{tabular}{|l|l|l|}
\hline Process or fuel & Case A & Case B \\
\hline Waste incineration [GWh] & 1560 & 1553 \\
\hline Wood [GWh] & 144.7 & 142.6 \\
\hline Coal/Rubber [GWh] & 38 & 37.1 \\
\hline Oil [GWh] & 6.9 & 6.6 \\
\hline Biogas [GWh] & $31.7 *$ & $32.2 *$ \\
\hline Total heat production [GWh] & 1459 & 1459 \\
\hline Total electricity production [GWh] & 256.6 & 264.6 \\
\hline CCGT electricity production [GWh] & 0 & 21.5 \\
\hline Electric bus electricity use [GWh] & 0 & 8.0 \\
\hline Local CO2-eq emissions [million kg] & 232.5 & 231.1 \\
\hline $\begin{array}{l}\text { CO2-eq emissions with subtraction for excess } \\
\text { electricity production [million } \mathrm{kg}]\end{array}$ & 232.5 & 230.1 \\
\hline
\end{tabular}

*a small difference in biogas use is caused by the numerical method.

Fig. 24 shows the fuels and services that are directly involved in the fuel-energy flow for the regional biogas described in Case B. Fig. 25 shows differences between Case A and Case B concerning fuel use and electricity production. 


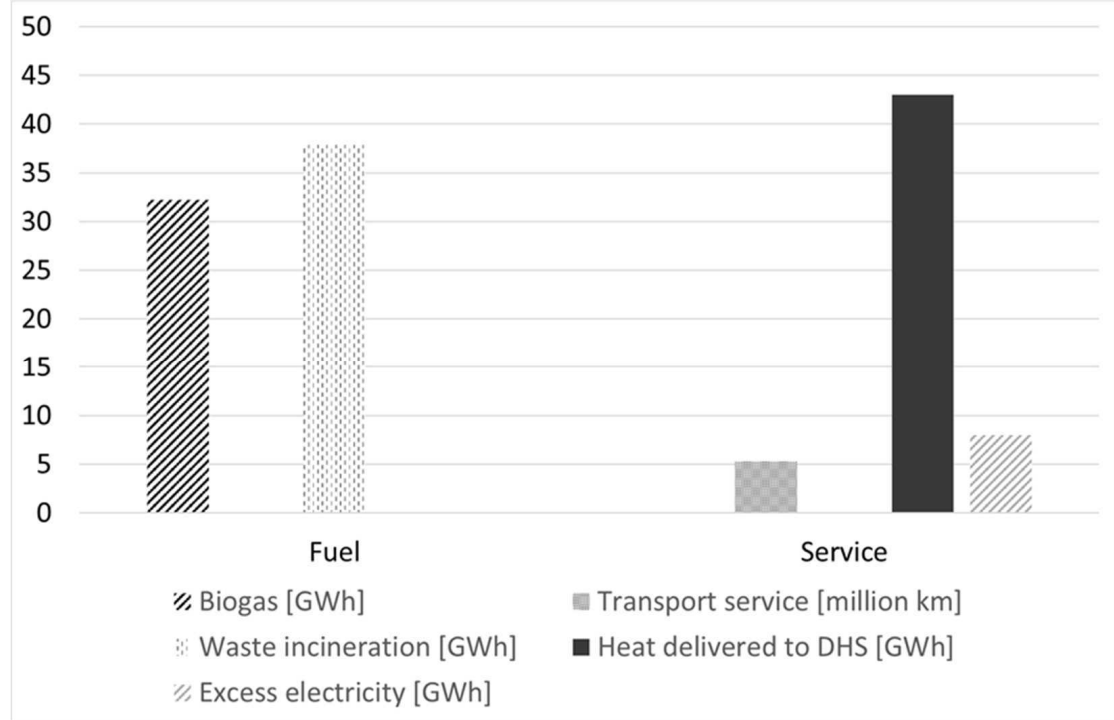

Figure 24. Fuels and services in the integrated system in Paper II.

In Case A the fuel-energy flow is a simple flow where $32 \mathrm{GWh}$ biogas fuel results in 5.3 million $\mathrm{km}$ bus transport service. The more complex energy system service produced in Case $\mathrm{B}$ is shown in Fig. 24, where two fuels give three services. One way to assess the value of the system integration in Case B, compared to Case A, is to examine the added system service. Moving from Case A to Case B, $38 \mathrm{GWh}$ waste incineration is added on the fuel side, while at the same time $43 \mathrm{GWh}$ of "heat delivered to DHS" is added and $8 \mathrm{GWh}$ "excess electricity production" is added. Hence, the system integration is beneficial because more services are produced with less fuel. This becomes easier to see when the entire system is studied. Table 13 shows model results for the entire systems, Case A and Case B. Only Case B uses electric buses and the CCGT. Apart from that the greatest difference between the cases is for the electricity production, where there is a $4 \%$ increase comparing Case $\mathrm{B}$ with Case A. The greater electricity production is a consequence of the use of CCGT which has the highest electrical efficiency in the CHP system. Case B also has lower fuel use for waste, wood, coal/rubber and oil. Emissions are $1 \%$ lower for Case B if excess electricity production is considered. In relation to the annual load for the integrated system, the differences between Case A and Case B become small. However, in relation to the biogas flow, the differences are substantial. 


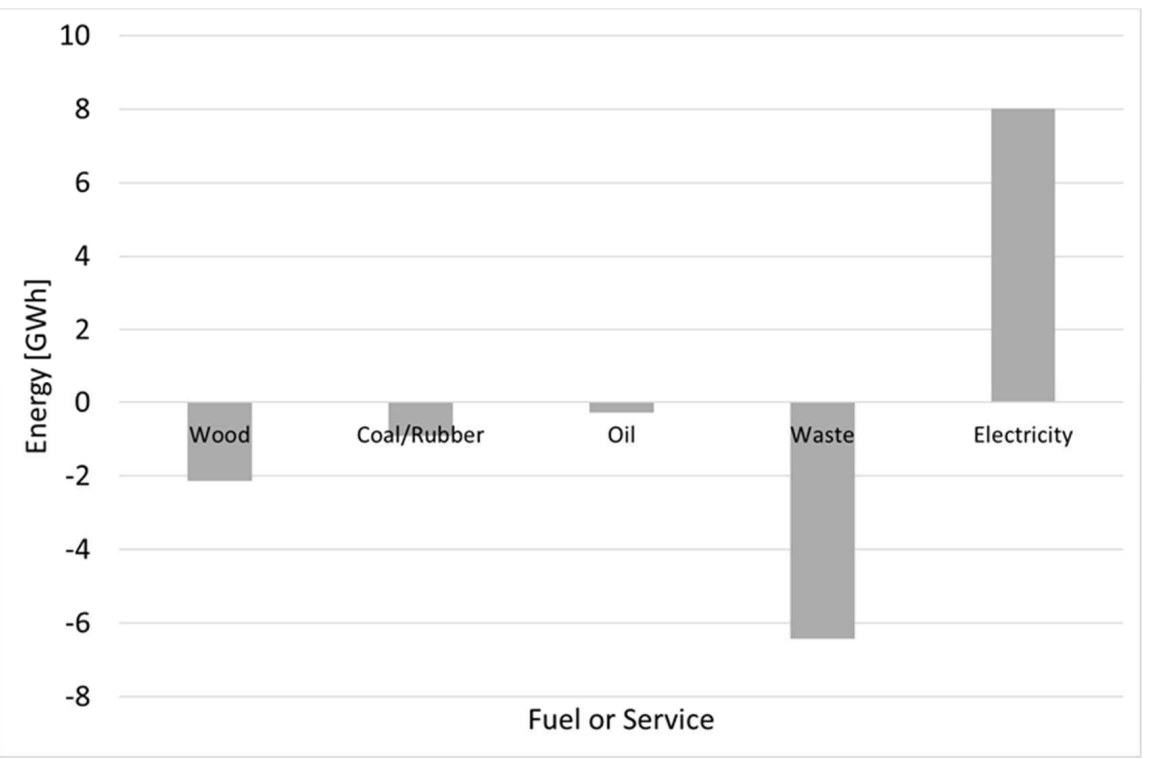

Figure 25. Differences in used fuel and electricity production between Case A and Case B.

\subsection{2. $\mathrm{CO}_{2}$-eq emissions}

Fig. 26 shows differences between Case A and Case B regarding $\mathrm{CO}_{2}$-eq emissions.

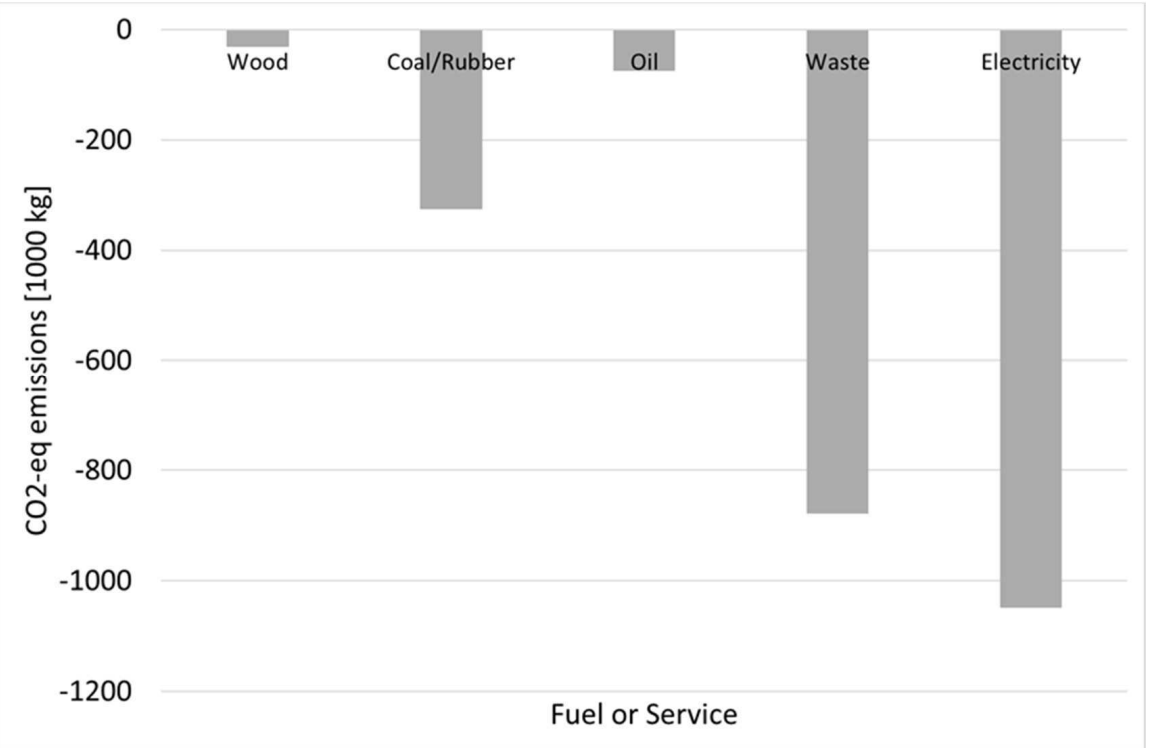

Figure 26. Differences in CO2-eq emissions [1000 kg] between Case A and Case B. Emission values for each fuel from Table 10.

Increased electricity production from the CHP-DHS will replace other electricity production in the electricity market. Here the average emission value for electricity production in the Nordic region is used to calculate the effect of that replacement. The $\mathrm{CO}_{2}$ reduction is greatest 
for increased electricity production. Lowered waste incineration has the second largest reduction in $\mathrm{CO}_{2}$ emissions and coal/rubber combustion the third largest. The uncertainties in the top-down method should be emphasised regarding exact emission values. The interesting result is not the exact emission values but rather the overall tendency of a general fuel saving and an efficiency gain. 


\subsection{Methodological critique}

The ambition when using a top-down method with inclusion of external effects is to come as close as possible to a net emission value for the studied system or the studied system change. As described earlier in section 2.7. this is not an easy task. Table 14 and Equation 2 show how the $\mathrm{CO}_{2}$ emissions are calculated in Paper I when both electricity market effects and fuel market effects are included. In the calculations that are presented in section 4.1-4.3 the rest term $\mathrm{R}$ in Equation 2 is equal to zero. However, the "true" value of this term is always unknown, and it is very unlikely that it is zero.

Equation 2: $\quad \mathrm{E}_{\text {tot }}=\mathrm{F}_{\mathrm{wood}} * \mathrm{I}_{\mathrm{wood}}+\mathrm{F}_{\mathrm{oil}} * \mathrm{I}_{\mathrm{oil}}+\mathrm{F}_{\mathrm{waste}} * \mathrm{I}_{\mathrm{waste}}+\mathrm{F}_{\mathrm{c} / \mathrm{r}} * \mathrm{I}_{\mathrm{c} / \mathrm{r}}-\mathrm{A}_{\mathrm{AEP}} * \mathrm{I}_{\mathrm{AEP}}-\mathrm{A}_{\mathrm{AFU}} * \mathrm{I}_{\mathrm{AFU}}+\mathrm{R}$

Table 14. Definitions of symbols in equation 2.

\begin{tabular}{|c|c|}
\hline $\begin{array}{l}\text { Equation } \\
\text { symbol }\end{array}$ & Description \\
\hline $\mathrm{E}_{\text {tot }}$ & Total emissions \\
\hline$F_{\text {wood }}$ & Fuel use - wood \\
\hline Foil & Fuel use - oil \\
\hline$F_{\text {waste }}$ & Fuel use - waste incineration \\
\hline $\mathrm{F}_{\mathrm{c} / \mathrm{r}}$ & Fuel use - coal/rubber \\
\hline $\mathrm{I}_{\mathrm{wood}}$ & Emission intensity - wood \\
\hline Ioil & Emission intensity - oil \\
\hline $\mathrm{I}_{\text {waste }}$ & Emission intensity - waste incineration \\
\hline $\mathrm{I}_{\mathrm{c} / \mathrm{r}}$ & Emission intensity - coal/rubber \\
\hline $\mathrm{A}_{\mathrm{AEP}}$ & Alternative electricity production \\
\hline $\mathrm{A}_{\mathrm{AFU}}$ & Alternative fuel use \\
\hline $\mathrm{I}_{\mathrm{AEP}}$ & Emission intensity - alternative electricity production \\
\hline $\mathrm{I}_{\mathrm{AFU}}$ & Emission intensity - alternative fuel use \\
\hline $\mathrm{R}$ & Unknown rest term \\
\hline
\end{tabular}

For example, it is possible to assume a term describing emissions from alternative use of the waste that is now incinerated, but this would be very hard to calculate due to the high complexity. To complicate things even more, the existence of a DHS probably even affects city planning, so we could argue that this should also be included in the calculations. The question is how? Many other effects could be considered, but if they are not included in a separate term then they are part of the unknown rest term $\mathrm{R}$.

The depth of the calculations cannot be infinite, and thus they are not exhaustive. If the researcher does not want to be too speculative, the researcher needs to limit the calculations to effects that are probable, foreseeable and quantifiable. A subjective selection process is needed to set the boundaries for the system study, and the author of this thesis cannot see any way to avoid this subjectivity. Some market effects are calculated while others are not. 


\subsubsection{Measurements and assumptions}

If the studied system is not a closed system, there is a need for assumptions at the system boundaries. Without such assumptions there will simply not be any calculation results.

When looking into the future there is an obvious need for assumptions, because things that have not yet happened cannot be measured. The emissions from newly introduced electric buses for example are harder to predict than emissions from a well-established technology like diesel driven buses. In order to evaluate results from a top-down analysis, it is crucial to know if input data are measurements or assumptions, and how reliable they are.

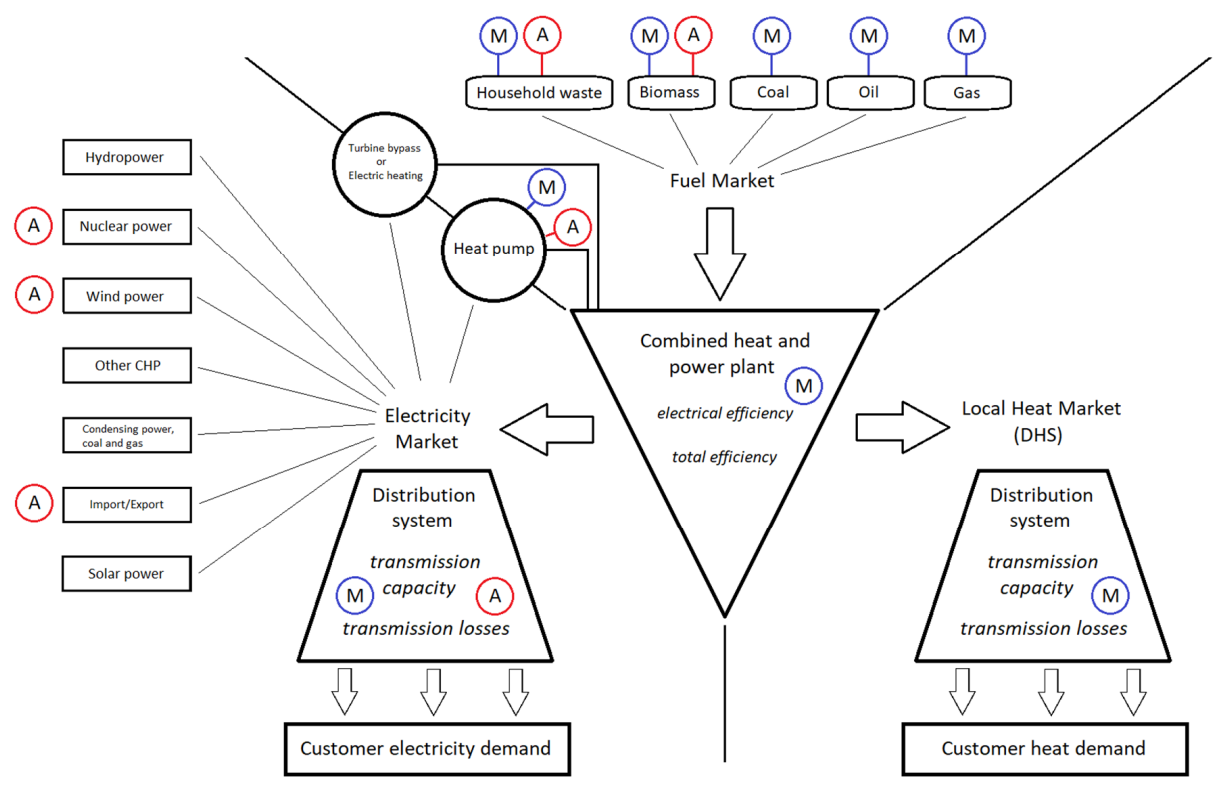

Figure 27. Schematic figure that illustrates measurements and assumptions in Paper I.

In Fig. 27 the schematic figure of the studied system is showed with markings for $\mathrm{M}-$ measurement and $\mathrm{A}$ - assumption. This figure illustrates the situation in Paper I. It was necessary to make assumptions in several model nodes. Regarding the dynamics in the power grid, some simplifications were made in describing Nuclear power, Wind power and Import/Export. Detailed descriptions for these nodes are hard to achieve and the circumstances are likely to change in the near future. Both wind power development and a possible decrease in nuclear power will certainly affect import/export flows. In Case 2 the assumption was made that the transmission capacity in the power grid was sufficient at all times during the year. The results from this study must be understood with that assumption in mind.

Assumptions must also be made regarding fuel emission values. The fossil fuel sources are easier than the renewable sources in this way. For a fossil source, a simple emission value from the combustion process together with added emissions for associated transports can 
probably come close to a "true" emission value. The household waste and the biomass fuels are more difficult to calculate and simplifying assumptions are needed. In both Case 2 and Case 3 simplifying assumptions were made regarding these fuels. Emissions were calculated with emission values from "The Environmental Fact Book" [48]. When using this calculation method, it also implies that several probable upstream consequences are omitted. For example, regarding household waste as fuel, the important issue of high material throughput in today's culture was left outside the scope of the calculations. That is the arithmetic consequence when no calculations are made regarding alternative use for the waste.

Another approach to waste incineration could be to regard the process as a driving force for material throughput in modern society. This approach is not unreasonable after looking, for example, at a content study of household waste performed by IVL Swedish Environmental Research Institute. This content study concluded that $18 \%$ of the garbage could be reused or sold at a second-hand store [35]. However, including calculations about the built-in energy from (wrongly) incinerated waste fractions would be too complicated for the calculations in this thesis.

\subsubsection{Sensitivity analysis - the relative weight of each assumption}

In the end of a top-down study the researcher needs to answer the question "Is this a useful result?". The end result will unavoidably include uncertainties in measurement, uncertain assumptions and excluded effects (consciously or unconsciously excluded). Performing a sensitivity analysis is one way to evaluate the quality of the study result.

The results from Case 1: A-E (section 4.1) are very sensitive to how emissions from electricity production are valued. The sensitivity is so high that different emission values for the electricity produced in the CHP-DHS determine which of the examined investment strategies are preferable. Only two of the five examined cases are not sensitive to how emissions from the electricity production are valued.

Regarding absolute emission values, the uncertainty in Case 3 (Paper II) is high. Uncertainties in emission values for both wood and waste are high and also the emission value for produced electricity. However, that study is mainly a case study where two different systems are compared. The uncertainty in absolute emission values is high but because all emission categories are in favour of Case 3: B (electric buses and CCGT), the outcome of the comparison between the two cases can be considered more certain.

The use of electric buses for inner city transport is a new technology and this implies that uncertainties about efficiencies are greater than for more established alternatives. To address this issue the model with electric buses was also calculated with lower efficiencies for the electric bus drive train. In Fig. 28 the excess electricity production from Case 3: B - the integrated system with CCGT is shown. 


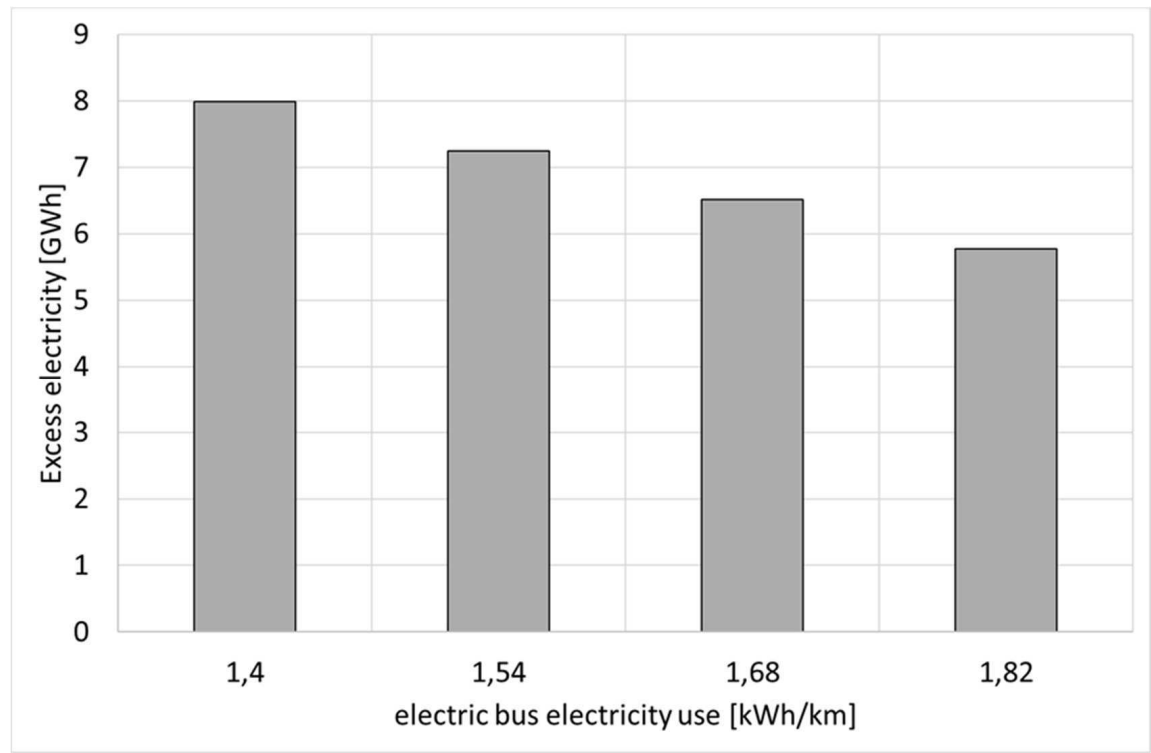

Figure 28. Excess electricity from Case 3: B with different values for electric bus efficiency.

The trend is obvious and expected: lower efficiency for the electric bus will leave lower excess production of electricity from the CHP-DHS. However, there is excess electricity production for the integrated system even with an electric bus efficiency of $1.82 \mathrm{kWh} / \mathrm{km}$. The value $1.82 \mathrm{kWh} / \mathrm{km}$ corresponds to a $30 \%$ electricity use increase compared to the calculated value used in the model. 


\subsection{Remarks on the assumption of the GHG Emissions}

Several Swedish power companies have, in recent years, produced what is known as a "GHG Emissions Disclosure" (in Swedish "Klimatbokslut") to communicate about their emissions of GHG. In their communication they rely heavily on a systems approach to highlight the benefits of combined heat and power, see [50],[51],[52],[53],[54]. Both alternative electricity production and alternative heat production are examined. However, regarding several important assumptions on the GHG Emissions, one can observe without doubt lack of scientific argumentation on other thinkable alternative assumptions on the sub-systems or in some cases a number of sub-systems are not problematised or acknowledged sufficiently.

Mainly, in the GHG Emissions Disclosure, the energy companies use calculations where four assumptions have a large arithmetic impact on the final result: the assumption about biomass as fuel, the assumption about household waste as fuel, the assumption about alternative heating, and the assumption about alternative electricity production. In Fig. 29 green circles show those sub-systems that the GHG Emissions Disclosure generally addresses and red circles important sub-systems that are not problematised or acknowledged sufficiently.

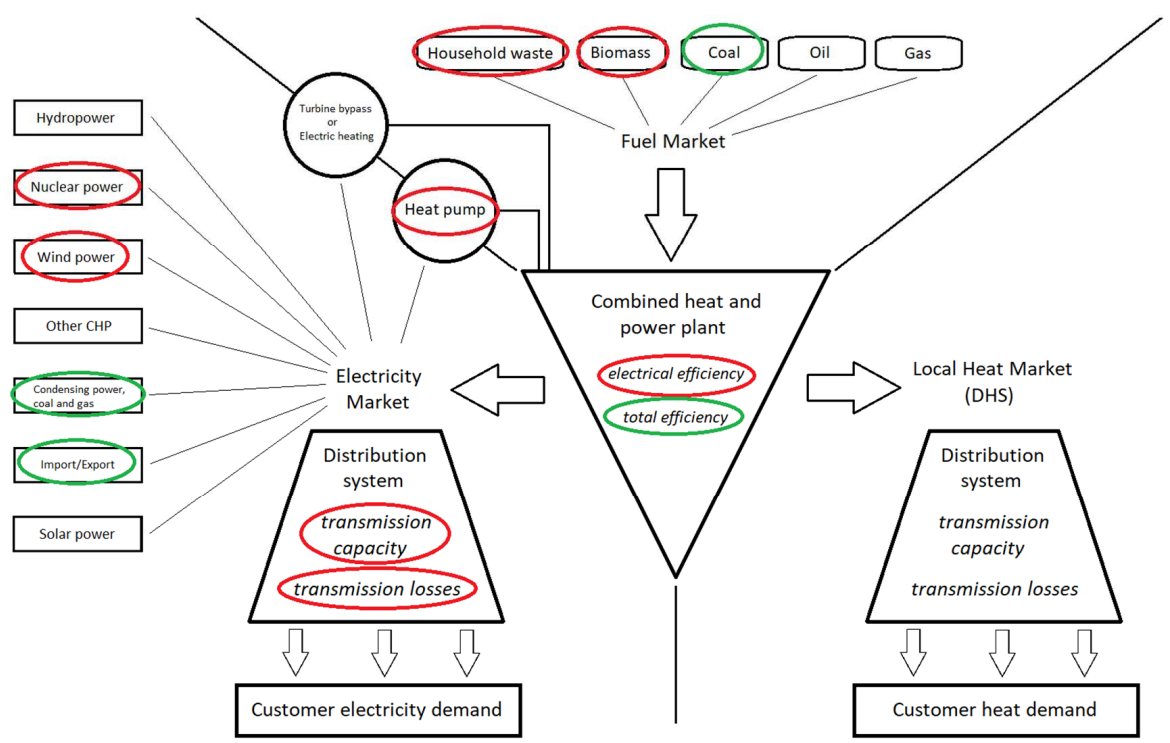

Figure 29. Schematic figure of the studied system. Green circles show sub-systems that the GHG Emissions Disclosure generally addresses and red circles important sub-systems that are not problematised or acknowledged sufficiently.

As mentioned in section 4.4.1, it is not easy to give an exact emission value for biomass. Schueler et al. [33] conclude that only $10 \%$ of the potential for biomass as fuel is without sustainability concerns. Harvey et al. [55] describe a "trilemma challenge", where the increased demand for food and energy puts pressure on the environment. These three aspects, food-energy-environment, cannot be treated separately because they all depend on each other and compete over land use. Hence, if treating biomass as a scarce resource, it is reasonable to treat the combustion process of biomass as a more complex issue than just a local combustion process with local emissions. In the studied GHG Emissions Disclosures, the companies consider biomass as $\mathrm{CO} 2$ neutral. However, in the calculations there is no specific forest area 
associated with the biomass growth that is needed to claim $\mathrm{CO} 2$ neutrality for the combustion process.

The companies that use household waste as fuel choose to compare burning household waste with an alternative use for the household waste, i.e. landfill. They choose not to address the built-in energy in the household waste and consequently not the important issue of high material through put in today's consumerist culture. Looking upstream, one possible alternative use for some fractions of the household waste is reuse, but they actively choose not to perform any calculations concerning this possibility. A more sophisticated approach could e.g. inform the reader of the GHG Emissions Disclosure about a content study of household waste performed by IVL Swedish Environmental Research Institute. This content study concluded that $18 \%$ of the garbage could be reused or sold at a second-hand store [35]. In the GHG Emissions Disclosures, both biomass and household waste are analysed without consideration about upstream consequences in their respective market.

The third important assumption is the assumption about alternative heating. In the GHG Emissions Disclosures, a very abstract comparison is made, where heating from DH is compared with a mixture of other heating alternatives in the heating market. The actual implementation of these alternative heating systems is not addressed, maybe because the implementation would involve major reconstructions in an entire city. Hence, one can clue that the energy companies choose to compare with a worse alternative that in reality will not happen.

In the research project "Control strategies for district heating" [17] it was concluded that the chosen system boundary is crucial when evaluating electricity production. If the system boundary is set around the European power grid, then marginal electricity production can be valued as coal condensing power when there is an increase or decrease in production [40]. In the examined GHG Emissions Disclosures, many energy companies clearly use the abovementioned system boundary.

It is also important to mention that a thorough presentation of the achieved electrical efficiency $\left(\eta_{\mathrm{el}}\right)$ of the CHP plant, which is an important quality factor, is often missing in the GHG Emissions Disclosures. In the GHG Emissions Disclosures where $\eta_{\mathrm{el}}$ is presented one can find values close to the threshold for tax-deduction for co-production of electricity and heat - a threshold set by the Swedish Government at $\eta_{\mathrm{el}}$ above $15 \%$ [56]. For many energy companies this figure could probably be higher with a different operational strategy of the turbines. In other words, the operational strategy has a tax-optimisation influence, but of course no information about this can be found in the GHG Emissions Disclosure. Information about the value of produced electricity is highlighted but actual actions to improve electrical efficiency are missing. A summary of the studied GHG Emissions Disclosures is presented in Table 15. 
Table 15. Summary of Climate Reports from five Swedish power companies. (Source: [50],[51],[52],[53],[54])

\begin{tabular}{|c|c|c|c|c|c|}
\hline Company & $\begin{array}{l}\text { Jönköping } \\
\text { Energi }\end{array}$ & $\begin{array}{l}\text { SSF } \\
\text { Stockholm }\end{array}$ & $\begin{array}{l}\text { Sundsvall } \\
\text { Energi }\end{array}$ & $\begin{array}{l}\text { Mölndal } \\
\text { Energi }\end{array}$ & $\begin{array}{l}\text { TvAB } \\
\text { Linköping }\end{array}$ \\
\hline $\begin{array}{l}\text { Emissions according } \\
\text { to GHG Emissions } \\
\text { Disclosure }\end{array}$ & $\begin{array}{l}-301,300,000 \mathrm{~kg} \\
\mathrm{CO}_{2} \mathrm{e}\end{array}$ & $\begin{array}{l}-927,000,000 \mathrm{~kg} \\
\mathrm{CO}_{2} \mathrm{e}\end{array}$ & $\begin{array}{l}-111,700,000 \mathrm{~kg} \\
\mathrm{CO}_{2} \mathrm{e}\end{array}$ & $\begin{array}{l}-134,900,000 \mathrm{~kg} \\
\mathrm{CO}_{2} \mathrm{e}\end{array}$ & $\begin{array}{l}-738,400,000 \mathrm{~kg} \\
\mathrm{CO}_{2} \mathrm{e}\end{array}$ \\
\hline $\begin{array}{l}\text { Valuation of biomass } \\
\text { as fuel }\end{array}$ & $\begin{array}{l}\text { Biomass } \\
\text { considered } \mathrm{CO}_{2} \\
\text { neutral }\end{array}$ & $\begin{array}{l}\text { Biomass } \\
\text { considered } \mathrm{CO}_{2} \\
\text { neutral }\end{array}$ & $\begin{array}{l}\text { Biomass } \\
\text { considered } \mathrm{CO}_{2} \\
\text { neutral }\end{array}$ & $\begin{array}{l}\text { Biomass } \\
\text { considered } \mathrm{CO}_{2} \\
\text { neutral }\end{array}$ & $\begin{array}{l}\text { No clear } \\
\text { information. } \\
\text { (Biomass only a } \\
\text { small fraction of the } \\
\text { company's fuel } \\
\text { mix.) }\end{array}$ \\
\hline $\begin{array}{l}\text { Valuation of } \\
\text { household waste as } \\
\text { fuel }\end{array}$ & $\begin{array}{l}\text { Emissions } \\
\text { calculated and } \\
\text { compared with } \\
\text { the alternative } \\
\text { use landfill. } \\
\end{array}$ & $\begin{array}{l}\text { Emissions } \\
\text { calculated and } \\
\text { compared with } \\
\text { the alternative } \\
\text { use landfill. } \\
\end{array}$ & $\begin{array}{l}\text { Emissions } \\
\text { calculated and } \\
\text { compared with } \\
\text { the alternative } \\
\text { use landfill. } \\
\end{array}$ & $\begin{array}{l}\text { Emissions } \\
\text { calculated and } \\
\text { compared with } \\
\text { the alternative use } \\
\text { landfill. }\end{array}$ & $\begin{array}{l}\text { Emissions calculated } \\
\text { and compared with } \\
\text { the alternative use } \\
\text { landfill. }\end{array}$ \\
\hline $\begin{array}{l}\text { Information about } \\
\text { electrical efficiency of } \\
\text { CHP in GHG } \\
\text { Emissions Disclosure }\end{array}$ & $\begin{array}{l}\text { No (but they } \\
\text { inform that one } \\
\text { power plant was } \\
\text { improved 2015) }\end{array}$ & No & No & No & No \\
\hline $\begin{array}{l}\text { Electrical efficiency } \\
\text { CHP }\end{array}$ & 0.21 & 0.18 & $\mathrm{~N} / \mathrm{A}$ & 0.23 & $0.16(2017)$ \\
\hline
\end{tabular}

There are numerous corporate actions that can be described as communication processes with the external world. Sometimes these communication processes are referred to as "public relations", and when it comes to environmental issues concepts like "corporate social responsibility" or "sustainable development" are often used. Siano et al. [57] have analysed the Volkswagen diesel scandal and conclude "The discrepancy between the ambitious commitments in the corporate sustainability reports and the actual actions of the organization highlights that greenwashing was involved in terms of both symbolic and substantive actions". Munshi et al. [58] wrote in 2005 how sustainable development and social responsibility were the current buzzwords in the corporate world. Through websites, reports and brochures, corporations began to communicate responsibility and care about creating positive images. Nowadays, being green is a well-developed market strategy. When this strategy is taken too far, it is often referred to as greenwashing [59], "Greenwashing - when aspects of reality are chosen (or not chosen)". 


\subsubsection{Understanding how to use marginal electricity}

In their GHG Emissions Disclosures, these companies refer to their electricity production as replacing marginal production in the European power grid. These companies have all delivered electrical power to the European power grid for a long time and their production should therefore be handled as an existing part of the European power balance. In order to use marginal production in the calculation one must address a change in the power production. This is not the case in this situation. Gode et al. [40] recommend using marginal electricity when referring to a change (production or use) and average electricity mix when emissions are divided between actors.

All power production units cannot claim to replace marginal production units because the calculation would then end up in mathematical nonsense. If we allowed all power production units in Europe to misuse mathematics in this way, we would end up with a spectacular figure for European $\mathrm{CO}_{2}$ emissions. Counting this way, using coal condensing power as the marginal electricity producer, European $\mathrm{CO}_{2}$ emissions for 2008 were roughly $-1.6^{*} 10^{\wedge} 12 \mathrm{~kg} \mathrm{CO} 2$ (3400 TWh, 2.9 \% Oil, 25.3 \% Coal, $23.1 \%$ Natural gas, $27.5 \%$ Nuclear, $19.6 \%$ Renewables, $1.6 \%$ Other fuels). Source fuel mix: European Environment Agency [60]). Counting this way, all power production units contribute negative emissions, except coal condensing power stations, which are considered $\mathrm{CO}_{2}$-neutral in this exercise in bad mathematics. 


\subsection{Using the best conversion pathways - a common interest?}

The pathway for one fuel can certainly affect both the pathway for another fuel and the size of the fuel-energy flow. However, the optimal solution for the whole system is not necessarily the aim for individual actors in the system. In theory, it can be an aim for individual actors, but in practice there are many other considerations that might lead the focus away from an optimal fuel-energy pathway. In large technical systems (LTS) there is always a path dependency, which means that once a particular technology is chosen, it will affect the development of the system for a long time (see, for example, Hughes [61]). In an investigation of two Swedish municipalities, Linköping and Norrköping, Palm [62] concludes that powerful actors, such as local energy companies, were able to mobilise support for policies, not least because they owned the energy plants and distribution networks:

The energy companies' managements and boards had an interest in - not least for economic reasons - continuing to use the existing plants and distribution network and, for example, continuing with waste incineration. The representatives of the energy company could argue that at least in the short term it was economic to continue to use the existing technical infrastructure. The energy companies could use their control over networks and plants as a resource in the struggle over how the energy system should develop. The energy companies showed that changing system direction would involve great costs, costs that no actor wanted to cover. [62]

Changes in large technical systems do not come easy. However, in one particular case, concerning biogas use as fuel in ICE buses, the local actors in Linköping have been supporting a fuel change process. Fallde et al. [63] describes how LITA, the municipally owned public transport company, began to investigate a fuel change from diesel to biogas in the late 1980s. After a test period between 1992 and 1994 a gradual switch from diesel buses to biogas was initiated. Linköping municipality introduced biogas driven buses to the regional transport system in 1997 and since 2015 all buses in the municipality have run on biogas. This process can also illustrate how slowly a technical transition phase can proceed. The fuel change for the buses took 23 years from test period to full implementation.

Palm et al. [64] conclude that the development of biogas buses was not only an issue of introduction of new vehicles. One of the involved actors (TvAB) also had an interest in selling gas and initiating large-scale biogas production. The best available fuel-energy pathway is thus not necessarily equal to the technological solution that will be implemented. And it can certainly also be debated which pathway is the best and which pathways are even possible to implement.

Now that the climate change issue has been widely acknowledged, "being green" has also developed into a market strategy for several companies. Taking this into consideration, a thousand biogas driven vehicles could be considered "greener" than biogas use in one (anonymous) CCGT. Efficiency and market strategy could then be in conflict and, in that situation, a "greener appearance" could defeat a measurable higher efficiency.

It is also not always easy to compare different fuel-energy pathways. In Paper II: Case 2, the biogas use is involved in a complex energy flow, as illustrated in Figure 30. In this case the biogas use affects waste incineration, DH heat production, electricity production and the fuel supply to cover the bus transport demand. The services produced by the biogas use are a bus 
transport service, a heating service and an electricity production service. The biogas use is also directly integrated with a waste incineration fuel-energy flow. It is reasonable to believe that the efficiency of this relatively complex fuel-energy pathway could be difficult to communicate to a broader audience.

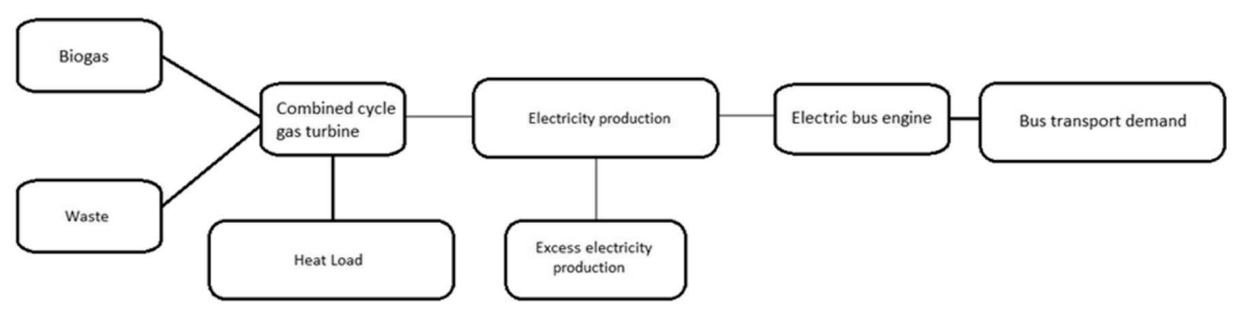

Figure 30. Fuel-energy pathway for the regionally produced biogas when the CCGT is used.

A top-down analysis can be helpful in finding good fuel-energy pathways. The value in a topdown analysis lies not in details about technical implementation nor in giving exact emission values for different technologies. The value lies in system knowledge that can be used to guide strategic decisions. This knowledge must also be valued in the context of other important factors, such as money, power and resources. The best available fuel-energy pathway might not be a common interest for the involved actors. 


\section{Conclusions}

The conclusions presented here are based on the case studies in Paper I, Paper II and the research project "Control strategies for district heating". All these case studies are based on models describing the CHP-DHS in Linköping municipality. Although this is only one CHPDHS, it has many similarities with CHP-DHSs in other Swedish municipalities. Regarding fuel use and electrical efficiency, the studied system is close to the Swedish average.

A basic assumption in this thesis is that the infrastructure in the already built DHSs constitutes a valuable asset and that it is wise to use and maintain these systems. Another basic assumption is that there will continue to be a demand for residential heating.

\subsection{Research question I}

How can a regional combined heat and power plant (CHP) in a district heating system (DHS) be improved to reduce global carbon dioxide emissions?

What is certain is that the energy carrier electricity has a higher quality than heat. Likewise, it is also certain that heat with higher temperature has a higher quality than heat at a lower temperature. The thermal power process begins with the combustion of fuel and this combustion process determines the temperature starting point. From this starting point the heat resource can be utilised in different technical conversion processes. During these conversion processes some of the heat can be transformed into electricity or direct mechanical work. Finally, the heat will reach the same temperature as the surrounding environment, at which point the energy flow from the combustion process has come to an end.

The conclusions are:

- Hardware investments at the CHP plant can improve electrical efficiency and thereby reduce $\mathrm{CO}_{2}$ emissions. The investments are in high pressure turbines, medium pressure turbines and preheaters. The size of the improvement is harder to quantify because it depends partly on unknown factors in the surrounding electricity market. In the studied system $\mathrm{CO}_{2}$ reduction could be as high as $40-60 \%$.

- For a CHP situated in a region where there is, or probably will be, a high volume of intermittent power production, investments in heat pumps are beneficial for the overall energy system efficiency.

- The regionally produced biogas would be used more efficiently if it were used directly in the CCGT, instead of being used in internal combustion engines in buses. The buses would instead be electrically driven. This biogas use would create a better integrated fuel-energy flow and reduce heat losses. 
- A fourth improvement is to reduce the system temperatures in the DHS. The article results show that efficiency gains will increase electricity production by about 1-3\%, and that greenhouse gas (GHG) emissions are reduced by 4-20\%. These improvements are dependent on demand side investments in the DHS and are therefore slow to implement.

\subsection{Research question II}

How can a systems approach help to assess how actions taken in a regional energy system have implications in surrounding energy systems?

- A systems approach is beneficial for evaluating how one actor, through market connections, affects the efficiency of the entire market. With a systems approach, suboptimisation can be avoided. In the case of the electricity market this is especially important because $\mathrm{CO}_{2}$ emissions differ greatly between different power production units. Hence, it is important for the entire system's emission values to avoid using the worst polluting power plants.

- A systems approach is also beneficial for giving value to general fuel savings. Without a systems approach, fuel savings for a low-polluting source such as biomass tend to be neglected because the possible improvement appears small. With a systems approach and the understanding that the biomass fuel market is connected to other fuel markets, general fuel savings are valued more highly. In Paper I there is a considerable difference between emission values for the studied system with fuel market connections and the same system without fuel market connections.

- Examining the fuel conversion pathway is important for utilising the fuel resource in the most efficient way. The case study in Paper II shows that in the regional energy system in Linköping municipality it would be beneficial to use the biogas in the CCGT in the local CHP plant.

- The systems approach can, as with many other tools, create false results when misused. With poor assumptions or assumptions that are adjusted to fit a specific purpose, a systems approach can be used for greenwashing. Several Swedish power companies do this in what they call a GHG Emissions Disclosure. A GHG Emissions Disclosure consists of deceptively shaped information that is being used to create a false image of the company. 


\section{References:}

1. Moriarty, P. and D. Honnery, What is the global potential for renewable energy? Renewable and Sustainable Energy Reviews, 2012. 16(1): p. 244-252.

2. Haberl, H., et al., Global bioenergy potentials from agricultural land in 2050: Sensitivity to climate change, diets and yields. Biomass and Bioenergy, 2011. 35(12): p. 4753-4769.

3. de Castro, C., et al., Global solar electric potential: A review of their technical and sustainable limits. Renewable and Sustainable Energy Reviews, 2013. 28: p. 824-835.

4. Hoes, O.A.C., et al., Systematic high-resolution assessment of global hydropower potential. 2017.

5. Energimyndigheten, Energiläget 2017. 2017.

6. Energimyndigheten, Energiläget 2015. 2015: www.energimyndigheten.se.

7. Lund, H., et al., 4th Generation District Heating (4GDH): Integrating smart thermal grids into future sustainable energy systems. Energy, 2014. 68: p. 1-11.

8. Council, E., 2030 CLIMATE AND ENERGY POLICY FRAMEWORK. 2014.

9. Agency, E.E. Sectoral greenhouse gas emissions by IPCC sector 2016 2019-06-18]; Available from: https://www.eea.europa.eu/data-and-maps/daviz/change-of-co2-eq-emissions-2\#tabchart 4.

10. Smith, R.W., 4 - Steam turbine cycles and cycle design optimization: Combined cycle power plants. Advances in Steam Turbines for Modern Power Plants, 2017: p. 57-92.

11. DRAX. 10\% of electricity now generated abroad. Q1 2019 [cited 2019 2019-06-20]; Available from: https://electricinsights.co.uk/\#/reports/report-2019-q1/detail/4-where-do-britainsimports-come-from-2?\&_k=q3g4cv.

12. Roßegger, U. and R. Ramin, Explaining the ending of Sweden's nuclear phase-out policy: a new approach by referring to the advocacy coalition framework theory. Innovation: The European Journal of Social Sciences, 2013. 26(4): p. 323-343.

13. Graabak, I., et al., Optimal planning of the Nordic transmission system with $100 \%$ electric vehicle penetration of passenger cars by 2050. Energy, 2016. 107: p. 648-660.

14. Life Cycle Assessment of Biofuels in Sweden. 2010, Lund University. Department of Technology and Society. Environmental and Energy Systems Studies.

15. Energimyndigheten, Produktion och användning av biogas och rötrester år 2016. 2016.

16. Börjesson, M. and E.O. Ahlgren, Cost-effective biogas utilisation - A modelling assessment of gas infrastructural options in a regional energy system. Energy, 2012. 48(1): p. 212-226.

17. Tommy Rosén, L.Ö., Storskalig styrning av fjärrvärme. 2017.

18. Hall, L.M.H. and A.R. Buckley, A review of energy systems models in the UK: Prevalent usage and categorisation. Applied Energy, 2016. 169: p. 607-628.

19. Blomqvist, S., et al., Analyzing the Performance and Control of a Hydronic Pavement System in a District Heating Network. Energies, 2019. 12(11): p. 2078.

20. Ehrlich, P.R. and J.P. Holdren, Impact of Population Growth. Science, 1971. 171(3977): p. 1212-1217.

21. Marian, R.C., The IPAT Equation and Its Variants. Journal of Industrial Ecology, 2000(4): p. 13.

22. Kates, R.W., Population and consumption: What we know, what we need to know. Environment, 2000. 42(3): p. 10-19.

23.

24. Alvarez, H., Energiteknik. 2006: Lund : Studentlitteratur, 2006

3. uppl.

25. Frederiksen, S. and S.E. Werner, District heating and cooling. 2013: Lund : Studentlitteratur, 2013. 
26. Kauko, H., et al., Dynamic modelling of local low-temperature heating grids: A case study for Norway. Energy, 2017. 139: p. 289-297.

27. La Fleur, L., P. Rohdin, and B. Moshfegh, Energy Use and Perceived Indoor Environment in a Swedish Multifamily Building before and after Major Renovation. Sustainability, 2018. 10(3).

28. Chvatal, K.M.S. and H. Corvacho, The impact of increasing the building envelope insulation upon the risk of overheating in summer and an increased energy consumption. Journal of Building Performance Simulation, 2009. 2(4): p. 267-282.

29. Sarbu, I. and C. Sebarchievici, General review of ground-source heat pump systems for heating and cooling of buildings. Energy and Buildings, 2014. 70: p. 441-454.

30. Østergaard, P.A. and H. Lund, A renewable energy system in Frederikshavn using lowtemperature geothermal energy for district heating. Applied Energy, 2011. 88(2): p. 479-487.

31. Churchman, C.W., The systems approach. A Delta book. 1968: New York, N.Y., 1968.

32. 2017 [cited 2017 2017-04-20]; Available from: http://www.drax.com/about-us/.

33. Schueler, V., et al., Global biomass potentials under sustainability restrictions defined by the European Renewable Energy Directive 2009/28/EC. GCB Bioenergy, 2013. 5(6): p. 652-663.

34. Lidberg, T., T. Olofsson, and L. Trygg, System impact of energy efficient building refurbishment within a district heated region. Energy, 2016. 106: p. 45-53.

35. $\mathrm{AB}, \mathrm{I.S.M} .$, Potential för ökad återanvändning - fallstudie återvinningscentraler. 2018.

36. Björklund, A.E. and G. Finnveden, Life cycle assessment of a national policy proposal - The case of a Swedish waste incineration tax. Waste Management, 2007. 27(8): p. 1046-1058.

37. Svensk_Energi, Elåret 2015. 2016.

38. Vattenfall_AB. 2017 [cited 201711 mars]; Produktionshistorik Ringhals]. Available from: https://corporate.vattenfall.se/om-oss/var-verksamhet/var-

elproduktion/ringhals/produktion-och-

driftlage/produktionshistorik/?_t_id=1B2M2Y8AsgTpgAmY7PhCfg\%3d\%3d\&_t_q=nedregleri ng\&_t_tags=language\%3asv\%2csiteid\%3af95a4f00-a0c6-415c-a29a-

eb64244e4301\&_t_ip=130.236.36.212\&_t_hit.id=Kwd_Kestrel_Library_Epi_Types_Pages_Inf ormationPageType/_7eb1dd5b-d8c4-4a95-8a88-f943872742c8_sv\&_t_hit.pos=2.

39. Energimarknadsinspektionen, Överföringsbegränsningar mellan Norden och Tyskland. 2015.

40. Jenny Gode, K.B., Agneta Persson, Louise Trygg, Miljövärdering av el ur systemperspektiv. 2009.

41. Stefan Peterson, C.D.L., Samband mellan flödespremie och returtemperatur. 2013.

42. Kensby, J., A. Trüschel, and J.-O. Dalenbäck, Potential of residential buildings as thermal energy storage in district heating systems - Results from a pilot test. Applied Energy, 2015. 137: p. 773-781.

43. Fredrik Wernstedt, C.J., Demostrationsprojekt inom effekt och laststyrning. 2009.

44. Codina Gironès, V., et al., Optimal use of biomass in large-scale energy systems: Insights for energy policy. Energy, 2017. 137: p. 789-797.

45. Börjesson, M. and E.O. Ahlgren, Biomass gasification in cost-optimized district heating systems-A regional modelling analysis. Energy Policy, 2010. 38(1): p. 168-180.

46. Judl, J., et al., Net environmental impacts of low-share wood pellet co-combustion in an existing coal-fired CHP (combined heat and power) production in Helsinki, Finland. Energy, 2014. 77: p. 844-851.

47. Sahu, S.G., N. Chakraborty, and P. Sarkar, Coal-biomass co-combustion: An overview. Renewable and Sustainable Energy Reviews, 2014. 39: p. 575-586.

48. Gode J, M.F., Hagberg L, Palm D. , Miljöfaktaboken 2011. Estimated emission factors for fuels, electricity, heat and transport in Sweden. 2011.

49. Olkkonen, V. and S. Syri, Spatial and temporal variations of marginal electricity generation: the case of the Finnish, Nordic, and European energy systems up to 2030. Journal of Cleaner Production, 2016. 126: p. 515-525.

50. AB, P., Klimatbokslut 2018 Jönköping Energi. 2019.

51. AB, P., Klimatbokslut 2018 Södra Storstockholms fjärrvärmenät. 2019. 
52. AB, P., Klimatbokslut 2018 Sundsvall Energi. 2019.

53. AB, P., Klimatbokslut 2017 Mölndal Energi 2018.

54. AB, P., Klimatbokslut 2018 Tekniska verken. 2019.

55. Harvey, M. and S. Pilgrim, The new competition for land: Food, energy, and climate change. Food Policy, 2011. 36: p. S40-S51.

56. Skatteverket. Skatter kraftvärme. 2019 [cited 2019 190614]; Available from: https://www.skatteverket.se/foretagochorganisationer/skatter/punktskatter/energiskatter/v erksamhetermedlagreskatt/kraftvarme.4.361dc8c15312eff6fd19412.html.

57. Siano, A., et al., "More than words": Expanding the taxonomy of greenwashing after the Volkswagen scandal. Journal of Business Research, 2017. 71: p. 27-37.

58. Imperializing spin cycles: A postcolonial look at public relations, greenwashing, and the separation of publics. 2005.

59. Myers, A., Greenwashing. 2018, Salem Press.

60. Agency, E.E., Electricity production by fuel EU-27. 2008, European Environment Agency.

61. Hughes, T.P., The Seamless Web: Technology, Science, Etcetera, Etcetera. Social Studies of Science, 1986. 16(2): p. 281-292.

62. Palm, J., Development of sustainable energy systems in Swedish municipalities : A matter of path dependency and power relations. 2006.

63. Fallde, M. and M. Eklund, Towards a sustainable socio-technical system of biogas for transport: the case of the city of Linköping in Sweden. Journal of Cleaner Production, 2015. 98: p. 17-28.

64. What Characterizes a System Builder? The Role of Local Energy Companies in Energy System Transformation. Sustainability, 2016(3). 

PAPER I 



\title{
Article
}

\section{Active Management of Heat Customers Towards Lower District Heating Return Water Temperature}

\author{
Tommy Rosén * and Louise Ödlund ${ }^{\dagger}$ \\ Division of Energy Systems, Linköping University, SE-581 83 Linköping, Sweden; louise.odlund@liu.se \\ * Correspondence: tommy.rosen@liu.se; Tel.: +4-601-328-1424 \\ † Formerly Trygg.
}

Received: 3 April 2019; Accepted: 10 May 2019; Published: 16 May 2019

\begin{abstract}
The traditional way of managing the supply and return water temperatures in a district heating system (DHS) is by controlling the supply water temperature. The return water temperature then becomes a passive result that reflects the overall energy efficiency of the DHS. A DHS with many poorly functioning district heating centrals will create a high return water temperature, and the energy efficiency of the DHS will be affected negatively in several ways (e.g., lower efficiency of the flue gas condenser, higher heat losses in pipes, and lower electricity production for a DHS with combined heat and power (CHP)). With a strategic introduction of low-grade heat customers, the return water temperature can be lowered and, to some extent, controlled. With the heat customers connected in parallel, which is the traditional setup, return water temperatures can only be lowered at the same rate as the heat customers are improved. The active management of some customers can lower the return water temperatures faster and, in the long run, lead to better controlled return water temperatures. Active management is defined here as an adjustment of a domestic heating system in order to improve DHS efficiency without affecting the heating service for the individual building. The opposite can be described as passive management, where heat customers are connected to the DHS in a standardized manner, without taking the overall DHS efficiency into consideration. The case study in this article shows possible efficiency gains for the examined DHS at around 7\%. Looking at fuel use, there is a large reduction for oil, with 10-30\% reduction depending on the case in question, while the reduction is shown to be largest for the case with the lowest return water temperature. The results also show that efficiency gains will increase electricity production by about $1-3 \%$, and that greenhouse gas (GHG) emissions are reduced by $4-20 \%$.
\end{abstract}

Keywords: district heating; system perspective; low-grade district heating; return water temperature

\section{Introduction}

Moriarty et al. [1] examine different scenarios for how global energy use may develop until 2050. They show that to mitigate the problem of greenhouse gas (GHG) emissions, global energy use growth cannot continue. This is because the amount of renewable energy (RE) will not be sufficient to replace the fossil fuels in today's energy balance. Instead of global energy use growth, Moriarty et al. [1] propose that the world will need to make do with far lower levels of energy use than we do today. Achieving this will mean that societies must re-examine their energy use and take measures to reduce energy demanding services and to use energy more efficiently. Other authors draw similar conclusions. Haberl et al. [2] estimate the bioenergy potential to $100 \mathrm{EJy}^{-1}$, corresponding to about $18 \%$ of today's global energy use. De Castro et al. [3] estimate the solar power potential to be $60-120 \mathrm{EJy}^{-1}$, corresponding to about 11-22\% of today's global energy use. With estimates for hydro power at about $187 \mathrm{EJy}^{-1}$ [4], corresponding to about $33 \%$ of today's global energy use, and with wind power being an 
intermittent source (although with high energy potential), it is clear that a reduction of energy use and increased efficiency are crucial elements to obtain a fossil free global energy use.

In parts of the world with colder climates (e.g. Canada, Russia, and the Nordic region), space heating makes up a considerable proportion of energy use. In 2013, Sweden had energy use in the residential and services sector of $146 \mathrm{TWh}$, while energy use for heating and tap water was $80 \mathrm{TWh}$, corresponding to roughly $1 \mathrm{kWh} /($ person*hour), and the most common energy carrier for heating and tap water was district heating at 47 TWh [5]. This means that district heating corresponds to one third of the energy use in this large sector. About one quarter of the fuels supplied to district heating (DH) in 2013 were from fossil sources [5], which means that GHG emissions from DH are not of a negligible size. About two thirds of the fuels supplied were biofuels, and the remaining part comes from various sources such as electricity, heat pumps, and waste heat [5].

In Sweden, district heating is highly developed and can be considered to have reached a period characterized by maintenance (see Figure 1). During the last 20 years, there has been neither a large expansion nor steep reduction in supplied heating energy from $\mathrm{DH}$.

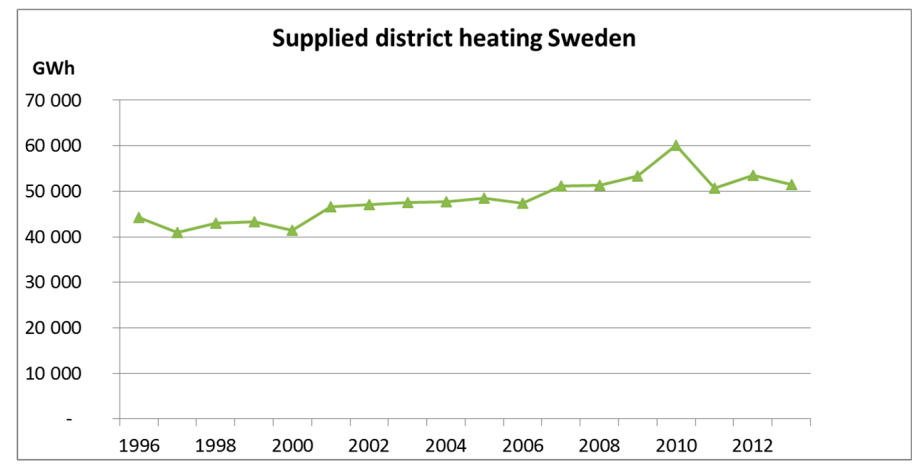

Figure 1. Supplied district heating in Sweden. The growth period for the district heating market is coming to an end and is moving into a period of maintenance. [2]

DH in Sweden can be considered a mature technological system, but moving into a period of maintenance does not imply that energy efficiency remains constant. Without good management and maintenance, energy efficiency will probably even decline as DH networks grow old. However, there should be a possibility to improve the overall energy efficiency, considering how management and maintenance are carried out. A key aspect of the possible improvements is moving from higher grade heat (high system temperatures) to lower grade heat (lower system temperatures)—see, for example, Lund et al. [6].

In the literature, low-grade heat is not a clearly defined concept. In an article about a low-grade heat recovery system for wood fuel cogeneration, Dagilis et al. [7] consider low grade heat to be around $50^{\circ} \mathrm{C}$, while in a comparison between different ORC ((Organic Rankine Cycle)) waste heat recovery systems, Ziviani et al. [8] consider low-grade heat to be $80-100^{\circ} \mathrm{C}$. There are more sources with other temperature limits, hence low-grade heat is not a clearly defined concept. In this article, low grade heat is regarded as heat between 30 and $50{ }^{\circ} \mathrm{C}$.

This paper aims to quantify the efficiency improvement potential in a moderate reconstruction of a district heating system (DHS), with the introduction of strategically placed low grade heat customers with the ability to store and use low grade heat. It is of great concern to examine the efficiency improvement potential in DHSs, considering that they account for a third of the energy use in the residential sector. 


\section{Traditional District Heating Technology}

The traditional system setup for a DHS is illustrated in Figure 2. There is a clear distinction between the supply side and the demand side. The supply side works as a slave to the demand side, and will adjust power to cover the heat load from the demand side. The demand side can be described by its heat load, measured in MW, but there is also a quality aspect of the heat load that needs a more precise description, including both supply temperature and return temperature.

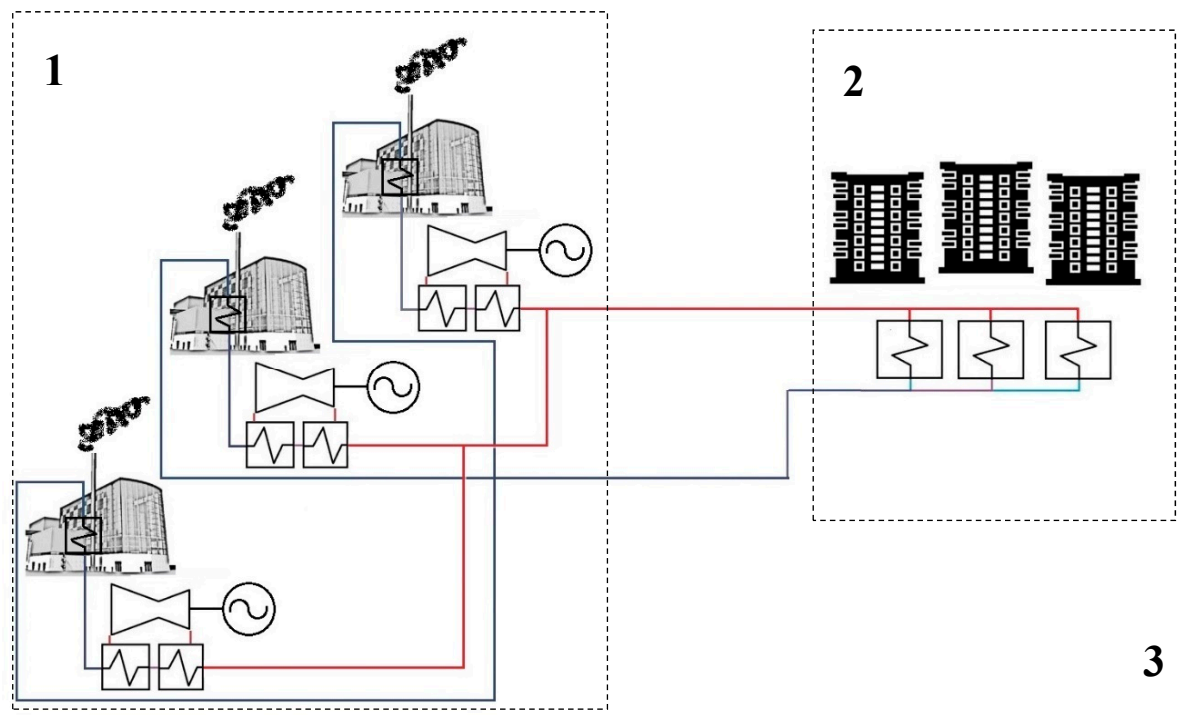

Figure 2. Illustration of a traditional district heating system: (1) Combined heat and power (CHP) power plants; (2) traditional heat load—district heat (DH) substations in parallel; (3) studied system with boundary connections to the fuel and electricity market.

The return water temperature from the demand side cannot be controlled by the supply side, but it will affect the power plant efficiency. A higher return water temperature will reduce the efficiency of both flue gas condensers (FGCs) and turbines.

In a DHS with several production units, there is a fuel merit order, for example, waste incineration, wood chips, coal, and oil. The last fuel in the fuel merit order will be used only to cover the peak power demand. Efficiency improvements for power plant components can reduce the time these peak power units will be operated, and hence reduce GHG emissions. The heat demand profiles in CHP systems have been examined by many authors (e.g., Lundström et al. [9] and Harrestrup et al. [10]), and the general conclusion is that reducing the peak power demand is favourable.

\section{Introduction of New Customers for Higher System Efficiency}

In the following paragraph, three views on a typical mature DHSs are presented, followed by a proposal for a technical improvement that would increase system efficiency. The three views are chosen to represent fundamental aspects of a DHS, namely, process control, energy delivery, and storage. By examining these three aspects of a DHS, the efficiency improvement potential of the system will be easier to analyse. 


\subsection{Three Views of a Typical Swedish DHS}

\subsubsection{First View-Temperature and Control}

Lund et al. [6] describe the opportunities and challenges for fourth generation district heating $(4 \mathrm{GDH})$, and how all generations of district heating technology have been moving towards lower system temperatures, both supply and return temperatures, thereby improving efficiencies and reducing heat losses. In a survey of supply and return temperatures in Swedish DHSs, the average annual supply temperature was $86{ }^{\circ} \mathrm{C}$ and the average return temperature was $47.2^{\circ} \mathrm{C}$ [11]. Roughly $20^{\circ} \mathrm{C}$ lower temperatures are possible if a common indoor temperature is considered to be $22^{\circ} \mathrm{C}$ and a temperature difference of $5{ }^{\circ} \mathrm{C}$ between radiator water and indoor air is added.

Another aspect of $4 \mathrm{GDH}$ described by Lund et al. [6] is higher complexity with more energy sources, both intermittent and controllable, and more advanced process control. Looking at a DHS in Sweden today, and only viewing a part of the system (e.g., a steam turbine or a modern radiator in an apartment), the DHS looks like a highly controlled energy system. However, a closer look at the system will reveal that parts of it are controlled, but a key entity in the DH network, the return water temperature, has no feedback control loop. In a process control context, this can be regarded as fairly primitive. The traditional way of managing supply and return water temperatures in a DHS is by controlling only the supply water temperature. The return water temperature then becomes a passive result that reflects the overall energy efficiency of the DHS. A DHS with many poorly functioning district heating centrals (low cooling) will create a high return water temperature, and for the overall energy efficiency of the DHS, this is negative in a number of ways (e.g., lower efficiency of flue gas condensers, higher heat losses in pipes, and higher electricity consumption in water pumps).

\subsubsection{Second View-Counter Flow Design Principle}

A basic design principle in steam turbine power plants is to conserve energy quality (exergy) by arranging heat exchangers in a counter flow arrangement. High enthalpy water, steam, or flue gas moving away from the heat source can heat water with slightly lower enthalpy flowing towards the heat source (boiler or reactor). In this way, the preheating of the feedwater will take place in one or more steps in power plant preheaters. More preheating steps will increase power plant efficiency, but will also mean higher building costs, so the number of preheaters installed is a trade-off between building costs and running costs. Extending this counter flow principle outwards from the power plant and into the district heating network would also mean higher efficiency, and this is of course also a trade-off between building costs and running costs. For individual dwellings, research has shown how better control and/or new radiators can reduce DH return water temperature and save fuel (see, for example [12-14]). For the district heating network, these kinds of actions in individual dwellings improve the overall network efficiency, but at a slow pace, considering that all dwellings must be improved to reach the full efficiency potential for the network.

\subsubsection{Third View-Heat Storage and Heat Leakage from Dwellings}

Thermal energy storage (TES) methods store energy by changing the temperature of a storage medium. In the built environment, commonly used materials for TES are water, rock, bricks, concrete, and soil. Research into energy storage in buildings normally focuses on positive effects for the individual building, and the optimization objective is understood to be the external energy input that is as low as possible. Hoes et al. [15] describe several different technical solutions to achieve a building that combines the benefits of a low thermal mass and a high thermal mass, and thereby reduces energy input. Naturally, all buildings store and leak heat in both the short term (hours) and the long term (days or weeks), and with planning and process control, this can be used to achieve better system efficiency. When talking about system efficiency, it is important to note which system efficiency is involved. In this case, it is the whole district heating system efficiency. A system perspective with wise 
system boundaries is important (see, for example, Churchman [16]). Here, a perspective regarding only the energy use for individual buildings would be too narrow.

Kensby et al. [17] describe how residential buildings in DH networks have the potential for short-term thermal energy storage by periodically overheating and underheating buildings. The company NODA uses a similar concept to reduce power peaks by up to $20 \%$, using a distributed software system that restricts power output for substations [18]. Both of these control methods act on the supply side of the DHS and can be used to alter the system load profile, but they will only have a minor impact on the return water temperature.

\subsubsection{Combining Views-Proposal for Better System Efficiency}

Combining these three views- - the uncontrolled return water to the DH power plant, the counter flow design principle of a steam turbine power plant, and thermal energy storage-leads to the suggestion of controlling the return water temperature by introducing low-grade heat customers with the ability to store and use low-grade heat inside dwellings. With the strategic introduction of low-grade heat customers situated in proximity to central production units (CHPs), the return water temperature can be lowered and, to some extent, controlled. This system design would also mean adding one more stage to the heat exchanger counter flow design, thereby increasing system efficiency. Figure 3 illustrates a DHS with low-grade heat customers.

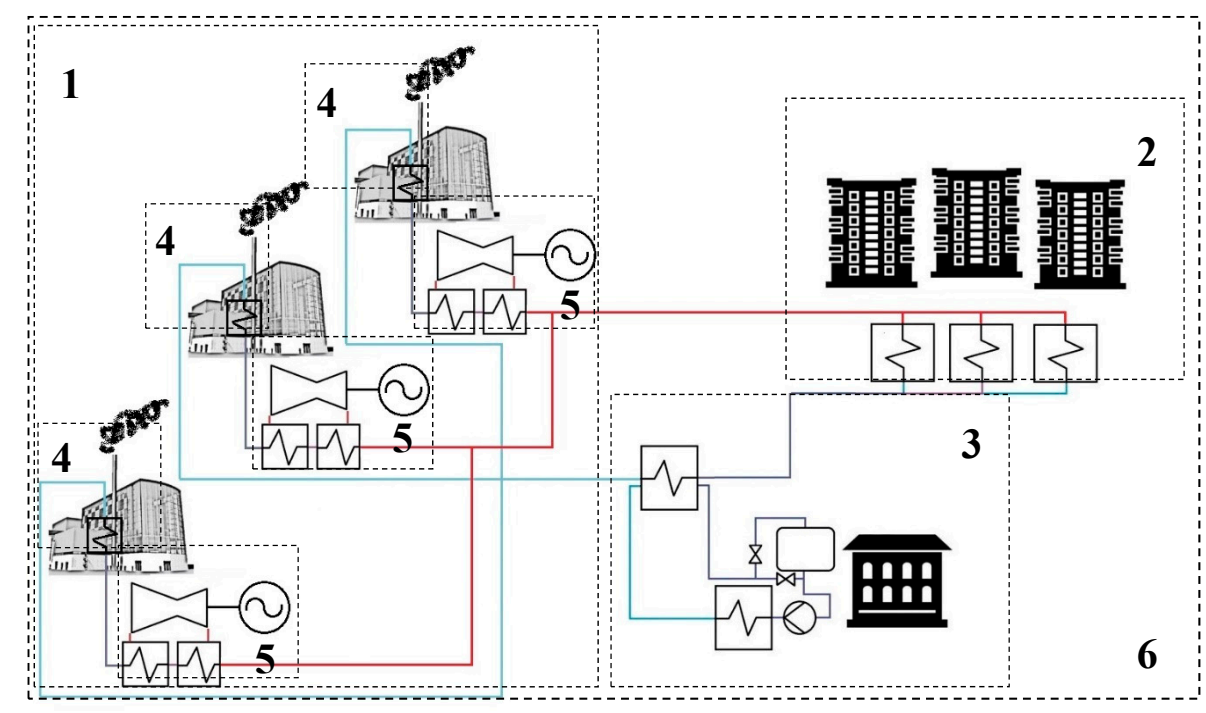

Figure 3. Illustration of a district heating system with controllable low-grade heat customers: (1) CHP power plants; (2) traditional heat load-DH substations in parallel; (3) low-grade heat customers; (4) temperature-dependent flue gas condenser (FGC); (5) temperature-dependent steam turbine; (6) studied system with boundary connections to fuel and electricity market.

With heat exchange using water from the return water pipe, this type of customer would be able to not only receive heat, but also improve overall efficiency for the DHS.

An improvement of a mature DHS would have to satisfy the following four points:

(1) Build on an existing system

(2) Reasonable costs and level of reconstruction

(3) Inclusion of life-cycle cost and emissions 
(4) Inclusion of boundary effects in surrounding markets such as the fuel market and the electricity market.

None of these four points are easy to address in an exact and clear manner, because of the high complexity of the DHS development. This can partly be explained by the large number of involved actors, and the fact that investments often stretch over a long period of time.

The implementation of these proposed low-grade heat customers would have to be carried out with some additional investments, compared with traditional heat customers connected in parallel. Implementation could be carried out with a combination of the technical solutions listed below.

- Counter flow heat exchange between the customer side and the return water side

- Increased radiator area

- Reduced water flow through radiators

- Batch delivery of heated water combined with a long cooling time

- Increased water volume in DHS, and the introduction of low temperature thermal storage tanks inside dwellings.

\section{Methodology}

In this study, the optimization software Model for Optimization of Dynamic Energy Systems with Time-dependent components and boundary conditions (MODEST) was used. The DHS system was represented in the model by four different kinds of nodes-fuel nodes, conversion nodes (boilers, turbines, and flue gas condensers), demand nodes (traditional heat customers and low-grade heat customers), and waste nodes (electricity production and heat losses). The power plants were described in terms of the efficiencies, maximum capacity, temperature-dependent power-to-heat ratio, and temperature-dependent flue gas condenser efficiency. The heat load profile was taken from measurements from 2015. The MODEST model is described in detail by Henning [19]. In recent years, several authors have used MODEST to analyse DHS, for example Lidberg et al. [20] and Gebremedhin [21]. MODEST is a top-down tool that can be used to represent the largest flows in an energy system. Figure 4 illustrates the workflow used in this study.

First, a base model based on power plant data and measurements was created. This model was optimized to cover the yearly heat load at the lowest cost. The optimization result determines which power plants are used for each time step in the model, which in turn gives the used fuels and the amount of electricity produced.

The base model was then adjusted with the introduction of low-grade heat customers and the resulting lower values for return water temperature and supply temperature. Efficiency values corresponding to each temperature were calculated with linear equations for each specific component (turbine or FGC). All of the models used the same yearly heat load.

After creating and optimizing parallel models, their results were compared and evaluated regarding efficiencies and fuel consumption, GHG emissions, and system costs.

\section{Methodological Difficulties and Boundaries}

This method is a top-down method, which means that the study starts at the top, in this case a regional energy system, and then moves down in finer and finer detail. At a certain degree of system detail, one needs to stop, but there is no distinct way to choose this level. In the time domain, this study starts with year, then moves to months, weeks, and days, and then stops. In the physical domain, this study starts with DHS in a municipality, then moves to supply side, power plants, and power plant components, and then stops. It is the opinion of the authors that more details in this model would not be beneficial for the calculations, but would rather add uncertainties. There are many details in the physical domain that are omitted, in some cases by choice, and in some cases by necessity. 
Because the DHS pipe structure is not included in the study, a choice was made to have all of the models use the same difference between the supply temperature and return water temperature. This choice is based on the linear characteristics for the specific heat capacity for water.

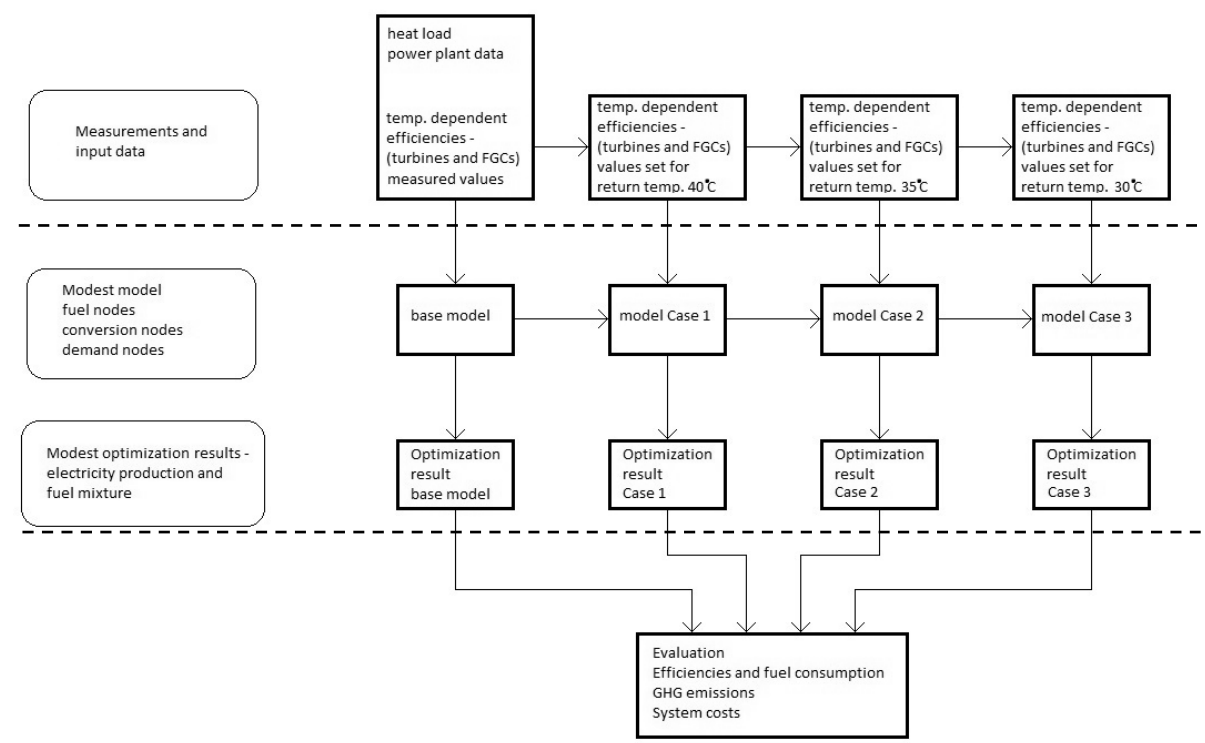

Figure 4. Schematic illustration of the workflow for the study. Horizontal lines show borders for the Model for Optimization of Dynamic Energy Systems with Time-dependent components and boundary conditions (MODEST) model.

Because this article does not evaluate a concrete technical solution, building costs and life-cycle costs are omitted, and the focus is instead on the overall efficiency potential.

\section{Case Study}

Linköping is a municipality with about 150,000 inhabitants, situated in the southeast of Sweden. Tekniska verken $A B$ is the regional power company and has a yearly production of $1500 \mathrm{GWh}$ heat and $260 \mathrm{GWh}$ electricity at two production sites. In the urban area, DH is the dominant way of supplying heat to multi-family buildings, small houses, and commercial buildings. The base load in the DHS is covered by waste incineration at CHP plants. With the increasing load, other CHP plants are starting to burn other fuels such as wood, rubber, coal, and oil. Heat only boilers are used to cover peak loads. The fuel merit order is as follows: waste, wood, coal/rubber, and oil. In daily production, the heat load determines how much power is needed from the power plant boilers, and the electricity production in this system is a by-product. CHPs in this region normally operate in an electricity market with low price, hence electricity production is not prioritized.

The optimization objective was to minimize the annual system cost while satisfying a given heat load demand. The fuel costs were fixed during the examined year, and were mainly set to force the model optimization algorithm to choose plants in the correct merit order. Details of the model are shown in Tables 1-4 and Figures 5 and 6. 
Table 1. Production units in Linköping's district heating system. FGC—flue gas condenser.

\begin{tabular}{ccccc}
\hline Power Plant & $\begin{array}{c}\text { Maximum Output } \\
\text { (MW Thermal Power) }\end{array}$ & Fuel & $\begin{array}{c}\text { Flue Gas Condenser Efficiency } \\
\text { (\% of Boiler Power) }\end{array}$ & $\begin{array}{c}\text { Steam Turbine } \\
\text { Efficiency (Electricity } \\
\text { Production/Input Heat) }\end{array}$ \\
\hline KV 50 & 72 & Waste incineration & $15-40$ & $0.10-0.15$ \\
\hline KV 61 & 66 & Waste incineration & $0-22$ & $0.17-0.27$ \\
\hline KV 1-wood & 60 & Wood & FGC not available & $0.18-0.26$ \\
\hline KV 1-coal & 60 & Coal/rubber & FGC not available & $0.18-0.26$ \\
\hline KV 1-oil & 120 & Oil & FGC not available & No turbine \\
\hline $\begin{array}{c}\text { HOBs (Heat only boilers, } \\
\text { several distributed in } \\
\text { DH network) }\end{array}$ & 240 & Oil & & \\
\hline
\end{tabular}

Table 2. Details of the Model for Optimization of Dynamic Energy Systems with Time-dependent components and boundary conditions (MODEST) model. DHS—district heating system.

\begin{tabular}{|c|c|c|}
\hline Variable & Linköping DHS & MODEST Model Linköping DHS \\
\hline $\begin{array}{l}\text { Temperature in supply flow and } \\
\text { return flow }\end{array}$ & $\begin{array}{l}\text { Supply: Measured on an hourly basis } \\
\text { Return: Measured on an hourly basis }\end{array}$ & $\begin{array}{l}\text { Represented in the model by a } \\
\text { function that affects efficiency in } \\
\text { turbines and flue gas condensers for } \\
\text { each time step }\end{array}$ \\
\hline Heat load & Measured daily in 2015 & $\begin{array}{c}\text { From } 2015 \text { measurements-monthly } \\
\text { duration }\end{array}$ \\
\hline Heat losses in distribution pipes & Not measured and not calculated & Not included \\
\hline Heat losses in flue gas & Not measured and not calculated & Included indirectly via FGC efficiency \\
\hline Flue gas condenser efficiencies & $\begin{array}{l}\text { Efficiencies measured with historic } \\
\text { values from 2010-2012 }\end{array}$ & $\begin{array}{l}\text { Included in model with linear } \\
\text { equation }\end{array}$ \\
\hline Electricity use for distribution pumps & $\begin{array}{c}\text { Measured value: } \\
4391 \text { MWh }(0.3 \% \text { of heat load })\end{array}$ & Not included \\
\hline Turbine efficiencies & $\begin{array}{l}\text { Efficiencies measured with historic } \\
\text { values from 2010-2012 }\end{array}$ & $\begin{array}{l}\text { Included in model with linear } \\
\text { equation }\end{array}$ \\
\hline Supply temperature management & $\begin{array}{l}\text { Active management can choose } \\
\text { between electricity production and } \\
\text { heat production }\end{array}$ & $\begin{array}{l}\text { Not included in model as a result of } \\
\text { the monthly duration heat load input. } \\
\text { Supply temperature in fixed relation } \\
\text { to return temperature }\end{array}$ \\
\hline
\end{tabular}

Table 3. Fuel prices in the model. CHP_combined heat and power.

\begin{tabular}{cc}
\hline Fuel & Price in Model \\
\hline Waste & 0 SEK/MWh \\
\hline Wood & 70 SEK/MWh \\
\hline Coal/rubber & 180 SEK/MWh \\
\hline Oil CHP & 320 SEK/MWh \\
\hline Oil HOB & 600 SEK/MWh \\
\hline
\end{tabular}


Table 4. Time division in the model.

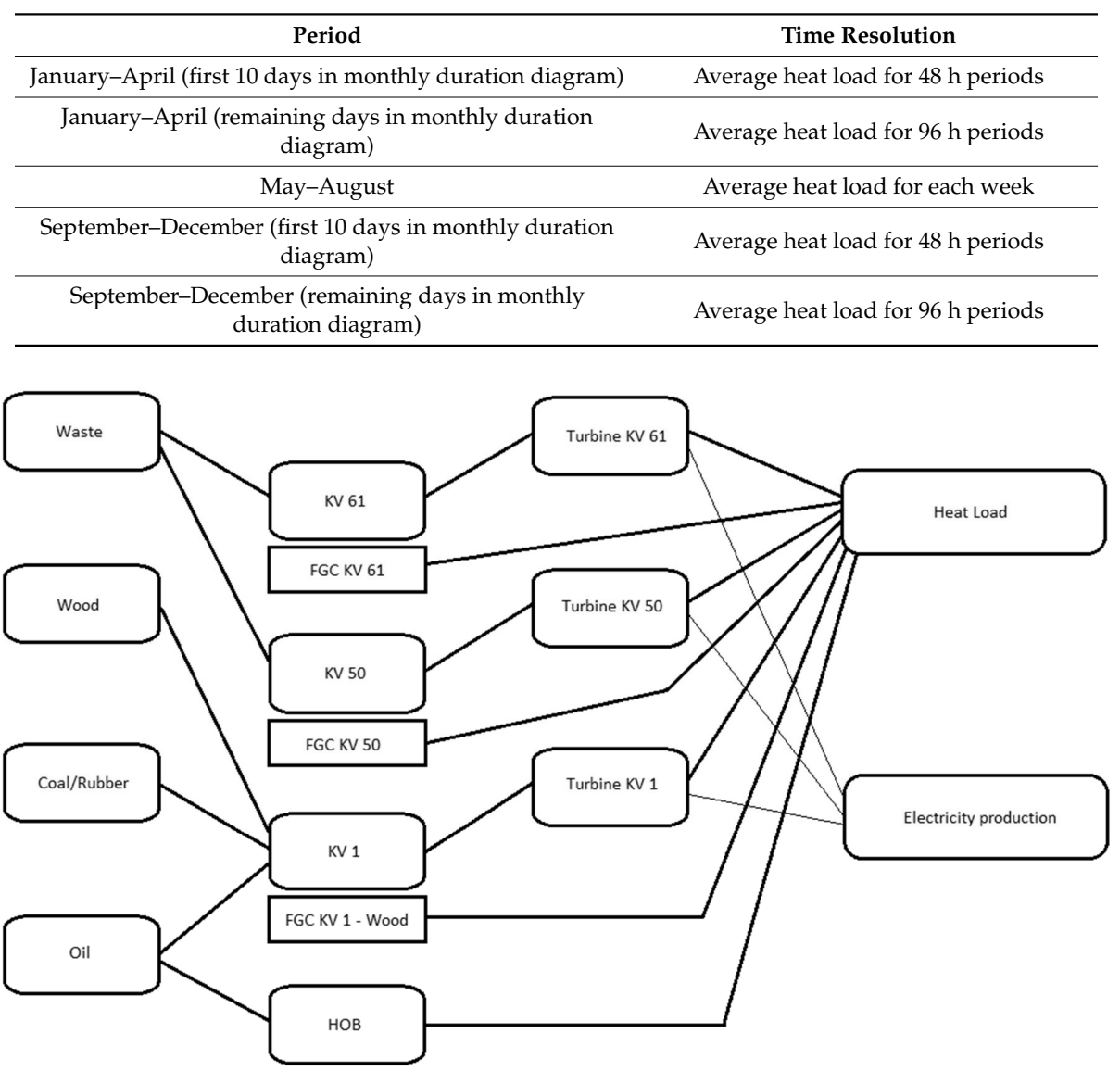

Figure 5. Illustration of nodes and flows in the model.

The heat load was modelled with the monthly duration diagram in Figure 6. The shortest time step used was $48 \mathrm{~h}$. In total, there are 96 time steps in the model. For each of these steps the optimization algorithm chooses which plants to operate in order to satisfy the heat load (the demand node in the model). The model time division is described in Table 4 . All of the fast transients (less than 48 hours) are handled with the power plant heat accumulator, so the $48 \mathrm{~h}$ time step is reasonable. It is also important to note that too short a time step, for example, an hour, will create false power peaks in the model that do not exist in the real CHP plant. These power peaks are handled by the accumulator. 


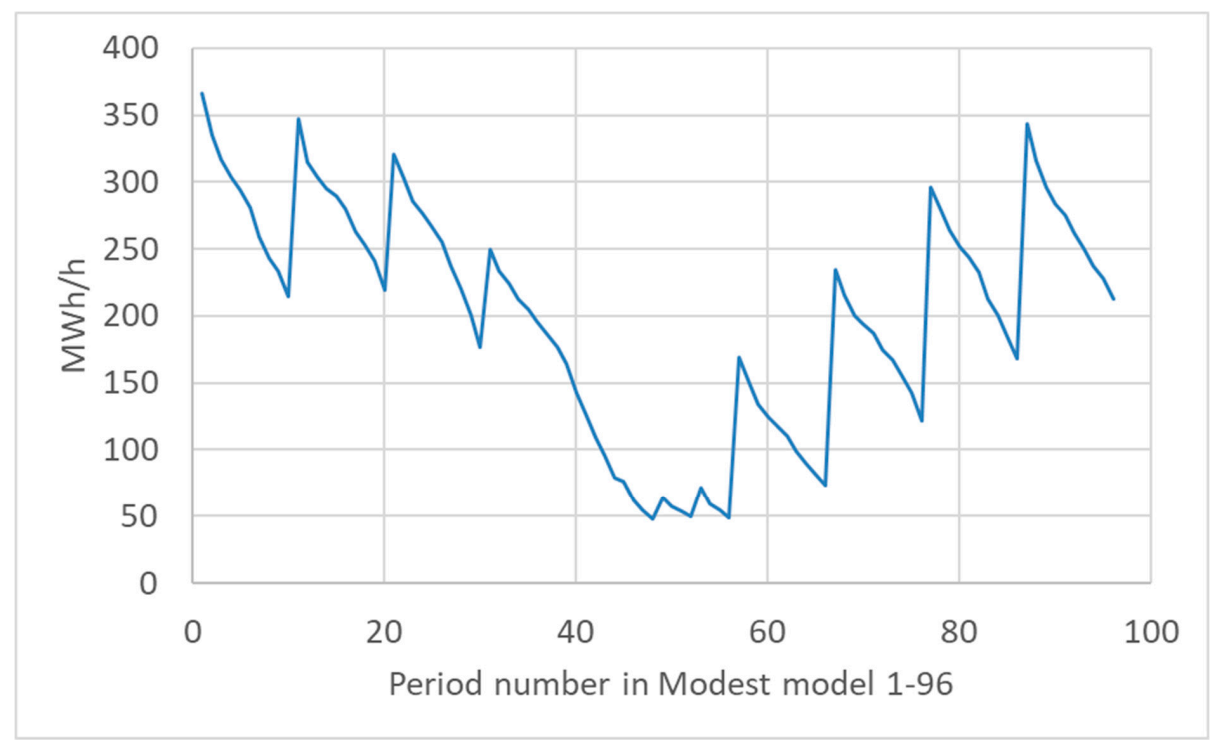

Figure 6. Heat load in the model, presented with monthly duration diagram (i.e., days sorted by heat load in each month). For days with higher heat loads are modelled in greater detail, see Table 4 .

\subsection{Temperatures in the Model}

In the MODEST model, the assumption was made that the difference between supply temperature and return temperature is equal to the measured base case, i.e. equal to differences compared to temperature measurements from 2015. Four different cases were examined: first a base case with data from measurements, then three different cases with return temperatures and corresponding supply temperatures. The modelled return temperatures were $40^{\circ} \mathrm{C}, 35^{\circ} \mathrm{C}$ and $30^{\circ} \mathrm{C}$. A summary of modelled cases is presented in Table 5 .

Table 5. Description of the studied cases.

\begin{tabular}{cc}
\hline Case & Description \\
\hline Base case & Efficiencies for turbines and FGC corresponding to temperature measurements from 2015. \\
\hline Case 1 & Low-grade heat customers with sufficient heat load to control return water temperature to $40{ }^{\circ} \mathrm{C}$. \\
\hline Case 2 & Low-grade heat customers with sufficient heat load to control return water temperature to $35^{\circ} \mathrm{C}$. \\
\hline Case 3 & Low-grade heat customers with sufficient heat load to control return water temperature to $30^{\circ} \mathrm{C}$. \\
\hline
\end{tabular}

The temperatures derived from measurements are presented in Figure 7. The temperatures used in the model are presented in Figure 8. The period of May-August was considered to be outside of the heating season, so this period did not have any temperature adjustments. 


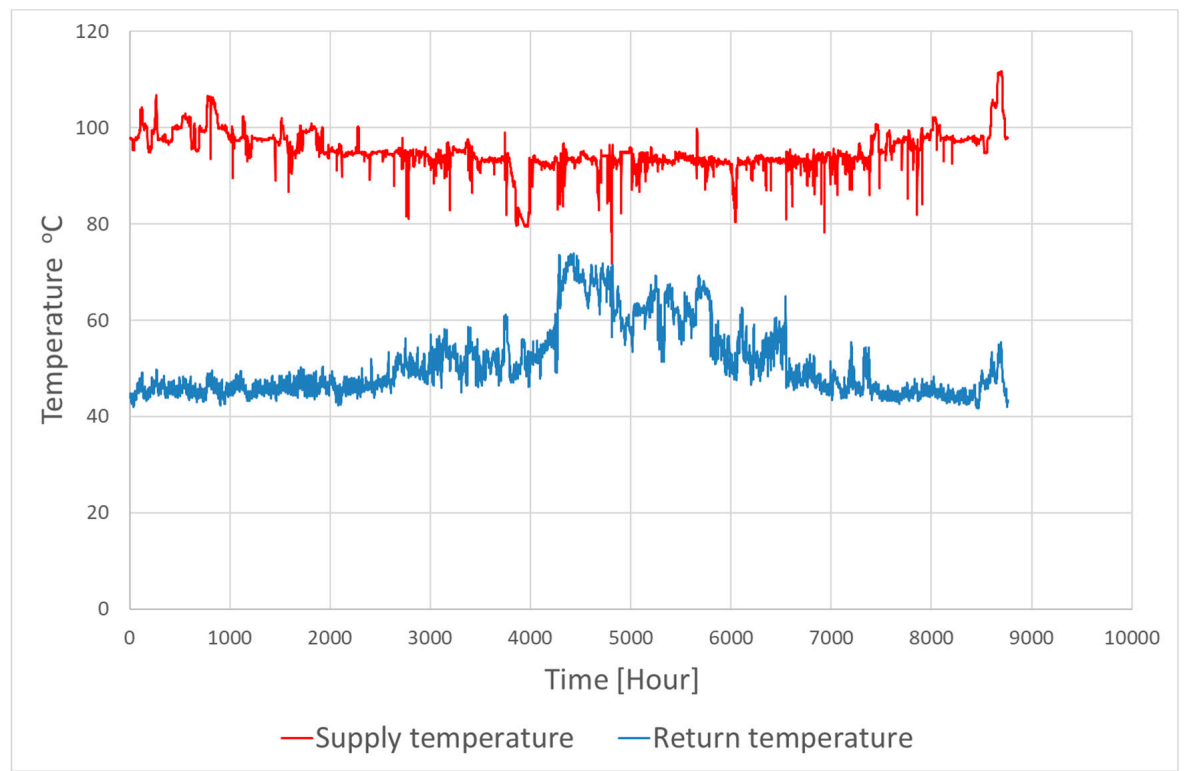

Figure 7. Measured supply and return temperatures in Linköping's DHS in 2015.

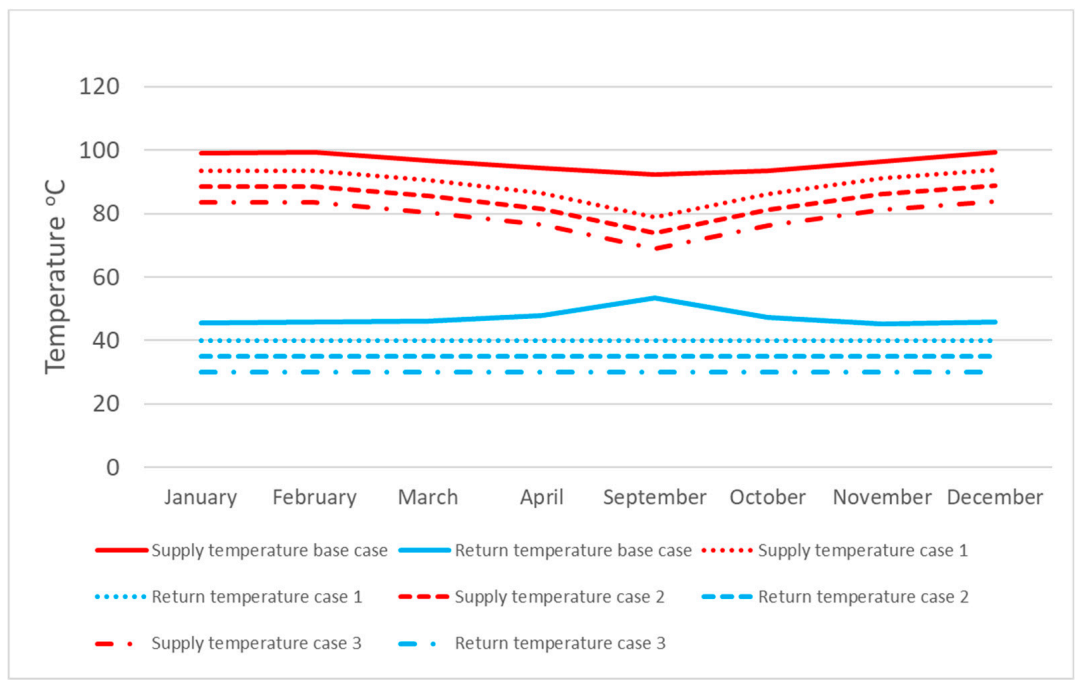

Figure 8. System temperatures in the MODEST model.

A small part of the district heating load in today's system needs a $90{ }^{\circ} \mathrm{C}$ supply temperature, so this was the lowest measured temperature during 2015. In this study, that temperature limit was omitted, as this part of the heat load can be supplied with an alternative solution, and is in fact not an absolute obstacle for lower supply temperatures for the rest of the DHS. 


\subsection{Efficiencies in the Model}

The efficiencies for backpressure turbines and flue gas condensers have been modelled with linear equations for each component. The linear equations have been calculated from plant measurements covering a period of several years. The measurements from a turbine can be seen in Figure 9, and the measurements from a flue gas condenser in Figure 10, and the equations for all of the temperature-dependent components can be seen in Table 6 . Looking at these measured efficiencies, it is obvious that they are not ideally linear. However, the most important aspect for this study is the temperature-dependent trend, which is clear for both electrical efficiencies and flue gas condenser efficiencies. A flue gas condenser extracts latent heat from the flue gas to the return water. A greater difference between the flue gas temperature and the return water temperature will increase the amount of extracted heat. For the flue gas condenser (FGC) in Figure 10, it is very clear that the lower limit for the measured efficiency has a strong correlation with temperature (i.e., a low return temperature is clearly beneficial to FGC efficiency).

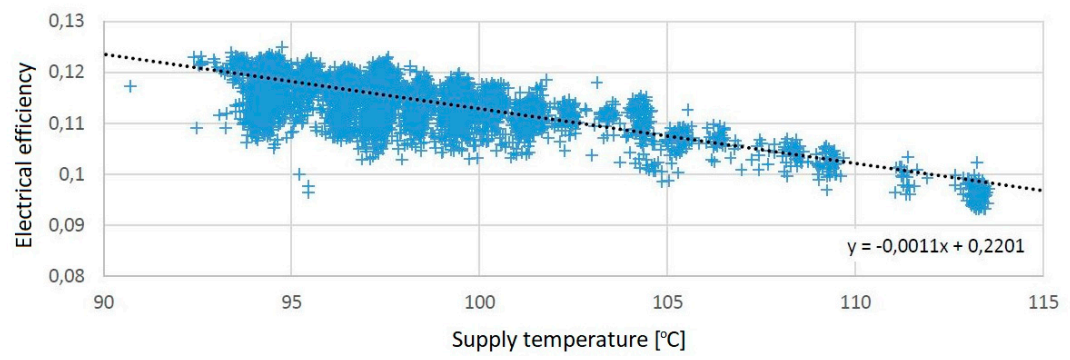

Figure 9. Measured efficiencies for KV50 turbine-waste incineration plant.

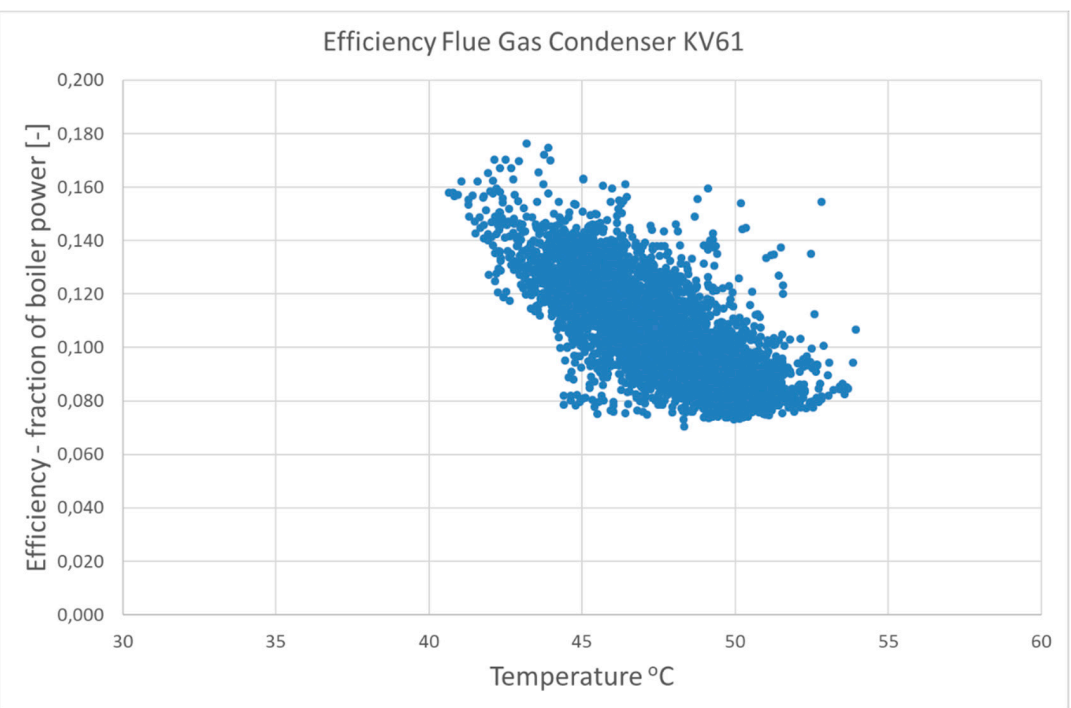

Figure 10. Flue gas condenser efficiency for KV 61 waste incineration unit. Samples are collected during several years and during different operation modes. There are variations in boiler power, fuel moisture, outdoor pressure, and so on. This gives a great data dispersion, but the temperature trend is clear. 
Table 6. Temperature-dependent efficiencies in the MODEST model $(\mathrm{Y}=$ efficiency as fraction of boiler power; $\mathrm{X}=$ temperature $\left.\left[{ }^{\circ} \mathrm{C}\right]\right)$.

\begin{tabular}{cc}
\hline Power Plant Component & Efficiency Equation, Fraction of Boiler Power \\
\hline Turbine KV $1^{* *}$ & $\mathrm{Y}=-0.0015 \cdot \mathrm{X}+0.3907$ \\
\hline Turbine KV 50 & $\mathrm{Y}=-0.0011 \cdot \mathrm{X}+0.2201$ \\
\hline Turbine KV 61 & $\mathrm{Y}=-0.0019 \cdot \mathrm{X}+0.3938$ \\
\hline Flue gas condenser KV 1 - wood & $\mathrm{Y}=-0.0064 \cdot \mathrm{X}+0.5557$ \\
\hline Flue gas condenser KV 50 - waste & $\mathrm{Y}=-0.0069 \cdot \mathrm{X}+0.54$ \\
\hline Flue gas condenser KV 61 - waste & $\mathrm{Y}=-0.0061 \cdot \mathrm{X}+0.394$ \\
\hline
\end{tabular}

** Turbine treated as one turbine, but is in reality three turbines, with condenser cooling water in serial connection-efficiency equation represents the turbine with the highest yearly load; this simplification leads to a slight overestimation of electricity production. One of these turbines could also be operated in "condensing mode", and is then cooled by a nearby river, this operation mode is seldom used and is not included in the model.

\subsection{Emissions in the Model}

The emission values in Table 7 are derived from The Environmental Fact Book [22]. Coal condensing power (CCP) was used as the marginal production unit in the European electricity market, and the turbine efficiency for these plants was considered to be $40 \%$. To evaluate the impact of the saved fuel, the assumption was made that the saved fuel is used in CCP to replace the coal (see, for example, [23,24].

Table 7. Emissions of greenhouse gas (GHG) $\mathrm{CO}_{2}$-eq for each fuel, The Environmental Fact Book [22].

\begin{tabular}{cc}
\hline Fuel & Emissions $\mathbf{~ k g ~ C O}$-eq/MWh \\
\hline Wood & 14 \\
\hline Oil & 288 \\
\hline Coal/rubber & 360 \\
\hline Waste & 136 \\
\hline Coal & 388 \\
\hline
\end{tabular}

\section{Model Results}

In this section, the results from the Linköping Municipality case study are presented in three different categories-efficiency, GHG emissions, and economic assessment. In Sections 6.1-6.3, the results are presented as relative values in comparison with the modelled base case in Figures 11 and 12 . Table 8 presents the absolute numbers for production and fuel use. The base case and the measured production from 2015 differ regarding the amount for each specific fuel. This is natural because the optimization model "chooses" the fuel and the power plants in a more simplistic way than the real power plant operators do. FGC KV1-Wood and FGC KV50 have not been operated at full power during 2015. However, in the modelled cases, all of the FGCs are assumed to be fully available. 


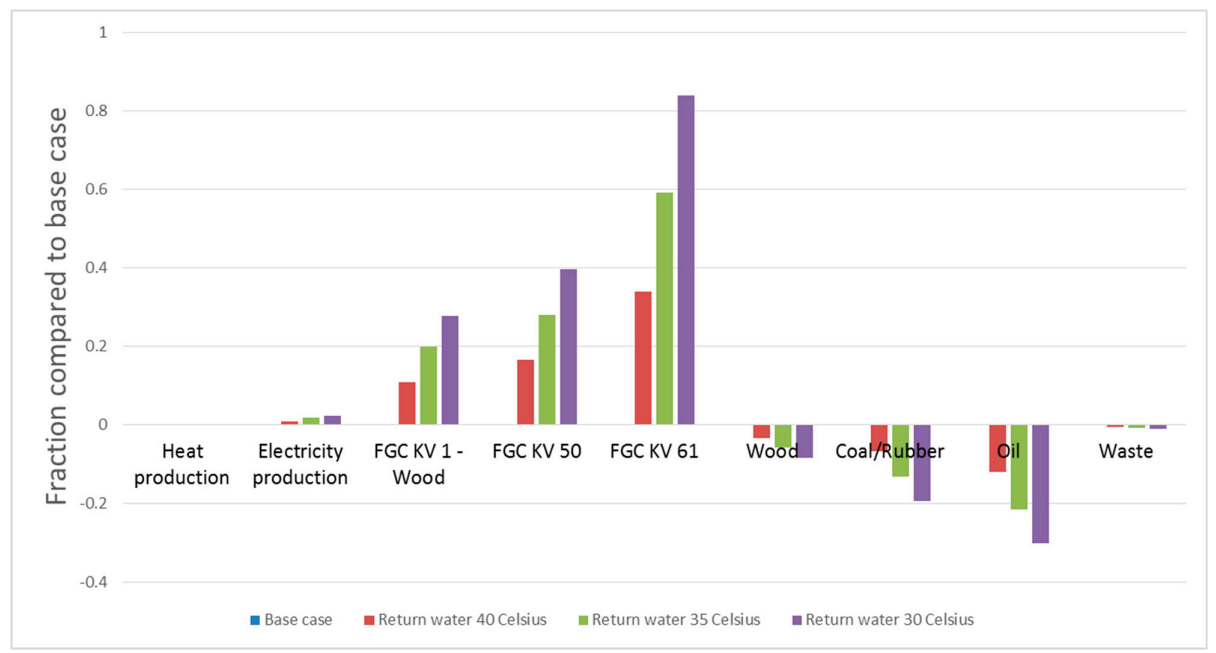

Figure 11. Modelled changes in whole year efficiencies and fuel consumption.

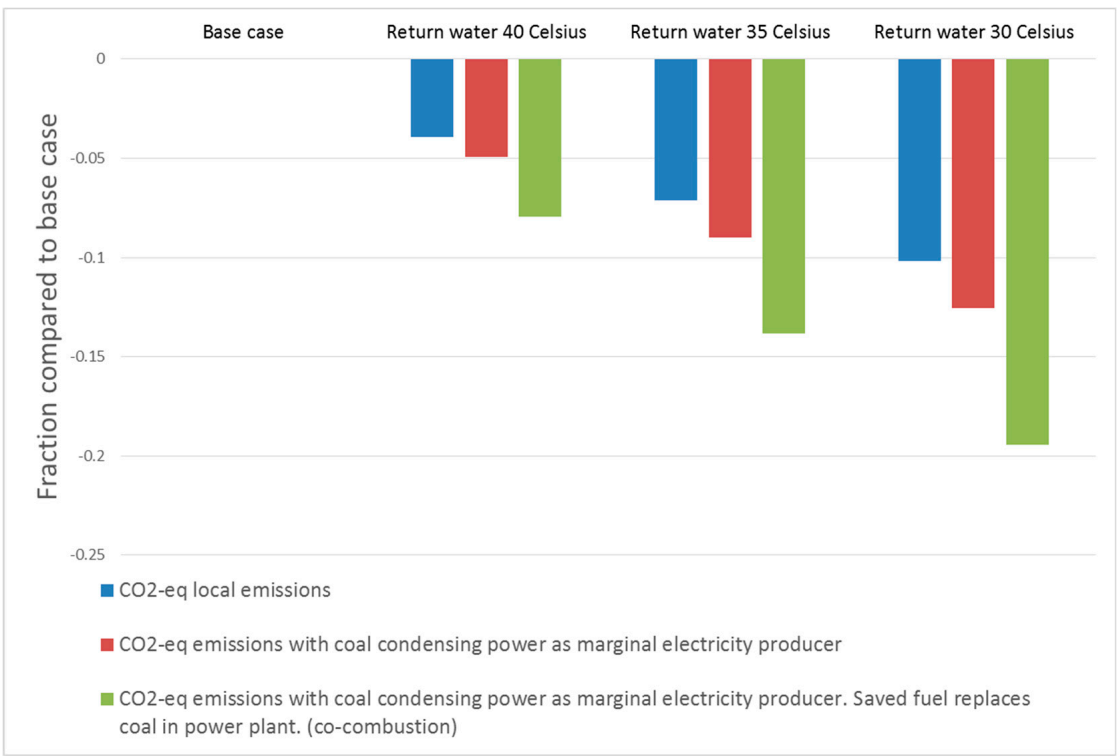

Figure 12. Modelled changes in GHG emissions for the examined cases with three different system boundaries. 
Table 8. Model results, production, and fuel use for all cases. The grey field presents measured production from 2015. All numbers in MWh.

\begin{tabular}{cccccccccc}
\hline Case & $\begin{array}{c}\text { Heat } \\
\text { Production }\end{array}$ & $\begin{array}{c}\text { Electricity } \\
\text { Production }\end{array}$ & $\begin{array}{c}\text { FGC KV } \\
\text { 1-Wood }\end{array}$ & $\begin{array}{c}\text { FGC } \\
\text { KV50 }\end{array}$ & $\begin{array}{c}\text { FGC } \\
\text { KV61 }\end{array}$ & Wood & Coal/Rubber & Oil & Waste \\
\hline $\begin{array}{c}\text { Measured } \\
\text { production 2015 }\end{array}$ & $1,481,617$ & 234,069 & 44,118 & 82,717 & 49,501 & 463,585 & 153,991 & 63,411 & $1,205,444$ \\
\hline Base case & $1,459,250$ & 276,534 & 69,418 & 123,998 & 40,994 & 333,435 & 212,109 & 122,962 & $1,137,138$ \\
\hline Case 1 & $1,459,250$ & 279,399 & 77,004 & 144,472 & 54,870 & 321,109 & 197,195 & 108,048 & $1,130,845$ \\
\hline Case 2 & $1,459,250$ & 281,722 & 83,253 & 158,764 & 65,216 & 313,657 & 183,661 & 96,408 & $1,127,948$ \\
\hline Case 3 & $1,459,250$ & 283,139 & 88,752 & 173,050 & 75,376 & 304,977 & 170,768 & 85,779 & $1,124,693$ \\
\hline
\end{tabular}

\subsection{Efficiencies and Fuel Consumption}

Heat production is a boundary condition in the model, so naturally, this will not differ between the base case and the three cases with controlled return water temperature. For fuel consumption, waste fuel is almost unchanged for all of the cases. This is natural, because it is a preferred fuel in the fuel merit order. Oil use has the largest reduction, with 30\% for Case 3. FGC heat is almost doubled, with an $84 \%$ increase for KV61 corresponding to $35 \mathrm{GWh}$ of free heat, which, in the base case, is lost with the flue gas. For Case 3, the total increase in FGC heat is $103 \mathrm{GWh}$, corresponding to around 7\% of the total DHS heat.

\subsection{GHG Emissions}

In this study, three different sets of emission data are presented. In an effort to include the market effects caused by the change in local electricity production for the studied DHS, marginal electricity production and marginal fuel consumption are added in evaluation methods 2 and 3 . Method 2 only includes market effects in the electricity market, while method 3 includes both the electricity market and the fuel market. In this article, the authors chose to present coal condensing power as the marginal electricity producer, in order to show two ways in which increased electricity production can be valued. To account for only local emissions is one way, giving no value to changes in electricity production. To account for avoided emissions from the most polluting source, coal condensing power, is another way. Olkkonen et al. [25] present calculations regarding the marginal electricity production for the Finnish, Nordic, and European energy systems, up until 2030. Their calculations indicate that during the winter season, coal condensing power has the largest share between the different marginal generation technologies.

1. Local emissions.

2. Emissions with the assumption that coal condensing power is the marginal electricity producer in the European electricity market.

3. Emissions with the assumption that coal condensing power is the marginal electricity producer in the European electricity market and the assumption that saved fuel replaces coal in the fuel market (co-combustion).

Changes in GHG emissions for the three different evaluation methods are almost linear with the return water temperature. This is a natural consequence of the underlying linear equation for FGC and turbine efficiencies in the model. The temperature trend is clear for all of the cases, but the choice of evaluation method has a strong impact on the absolute emission values. Case 3, evaluated with the third emission evaluation category, showed a reduction of almost $20 \%$ in GHG emissions.

\subsection{System Costs Assessment}

Higher FGC and turbine efficiencies give savings and higher earnings in accordance with Figure 13. Oil savings have the largest share, with about $50 \%$ of the total economic benefit. Case 3 showed an economic potential of SEK 25 million in yearly improvement; in comparison, it can be mentioned that fuel costs for 2015 were 105 SEK million. 
Table 9. Marginal fuel cost for power plant, real values from 2015, including taxes. Source: TvAB (the local energy company).

\begin{tabular}{ccc}
\hline Fuel & Electricity & Heat \\
\hline Waste & 0 SEK/MWh & 0 SEK/MWh \\
\hline Wood & 70 SEK/MWh & 70 SEK/MWh \\
\hline Coal/rubber & $170 \mathrm{SEK} / \mathrm{MWh}$ & $187 \mathrm{SEK} / \mathrm{MWh}$ \\
\hline Oil & $316 \mathrm{SEK} / \mathrm{MWh}$ & $342 \mathrm{SEK} / \mathrm{MWh}$ \\
\hline
\end{tabular}

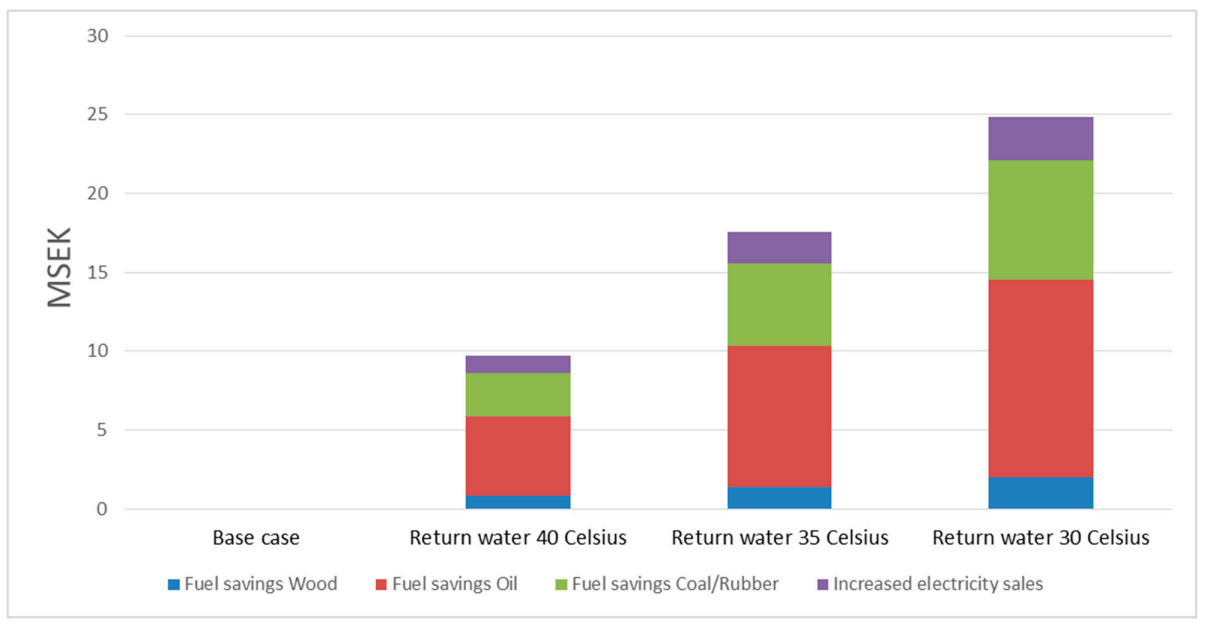

Figure 13. Economic figures for model results, 2015. Costs and earnings from Table 9.

In the figure above, an economic assessment is carried out using the marginal costs and earnings from Table 9 .

\section{Discussion}

\subsection{Static Benefits}

As the shortest time for the model time step used in this case study was 48 hours, the quantified results from this model can be considered static or at least quasi static. The static benefits are mainly derived from the alteration of the temperature working point for power plant components and the resulting efficiency improvements. The Linköping DHS has a 20,000 $\mathrm{m}^{3}$ heat storage tank on the supply side, which means that all of the fast load transients can be handled without changing power from the individual production units. In practice, this means that power plants can be operated with only a slow increase or decrease in power, and it also means that a model with long time steps can be a fairly good representation of the DHS.

The quantified results in Section 6 are all calculated in this quasi static timescale. There are also benefits in the shorter timeframe, but these benefits are highly dependent on the type of technical implementation that is used, and are therefore not quantified in this study. A general description of these benefits follows in the next section.

\subsection{Dynamic Benefits}

Dynamic benefits for the power plant can be regarded as the benefits in the timespan of 0 to 48 hours (i.e., shorter than the shortest time step in the model). Depending on how an implementation of 
low-grade heat customers would be carried out, the dynamic properties of the DHS would be different. Compared to today's system, where the power plant control is limited to the supply side heat storage, many benefits can be identified. These benefits are not included in the quantified benefits represented in Section 6.

An opportunity to use domestic integrated storage tanks as a buffer would make it easier to plan the power plant production. A demand side management (DSM) solution on the network return side would give the power plant the ability to react to the heat demand fluctuations in the network, instead of trying to forecast loads $4-6 \mathrm{~h}$ in advance. With process control terminology, this would mean feedback control instead of open loop control with weather forecasts.

With better process control and a larger heat buffer, a likely system impact is economic savings, because of the fewer starts and stops of individual power plants.

Higher electrical efficiency in the base load situation would give a wider control span in the choice between electricity production and heat production. This applies for both fast and slow transients.

A low-grade heat customer situated downstream from a malfunctioning district heating substation (bad cooling) can reduce the negative impact of the malfunction on the DHS.

\subsection{Evaluation of GHG Emissions}

The fuel mix for one particular CHP plant or one particular region is not the main issue when considering how markets are linked to each other in the global economy. There is not enough biomass on the planet to sustain our current use of energy [1], so if all efficiencies and demands remain at the same level, this implies that a fuel switch for one power plant will lead to a fuel switch in the other direction somewhere else. This is the fundamental conclusion to be drawn if we consider the resource limitations of our planet. In a fully connected and closed system, all emissions matter and all efficiencies matter.

To assess the global effects of the proposed action, electricity market connections alone are not enough-some system effects must also reach the fuel market. Here, we use the assumption that fuel that is saved because of higher efficiencies is instead used in co-combustion in CCP plants [23,24].

Considering ideal market connections for both the fuel and electricity markets, it is just as harmful to be inefficient with wood as with coal, because inefficiencies in one part of the system play out as higher marginal production for the entire system. In this article, we use coal condensing power as an estimate of that marginal production.

The need for a system perspective is crucial. Looking at this case study, the fuel efficiency gain is around $7 \%$ for the $30^{\circ} \mathrm{C}$ case, corresponding to $10 \%$ lower local GHG emissions, but that number is doubled to almost $20 \%$ if electricity market and fuel market connections are considered.

These idealized connections in the electricity market and the fuel market represent a somewhat simplistic view of the European energy system, but we argue that these connections are needed in order to make a fair evaluation of how efficiency gains should be valued.

Looking even further away from the studied object, there is also a possibility of rebound effects in connected markets, in technical systems, or in the form of lifestyle changes (see, for example, [26]). The rebound effect is omitted in this study, mainly because of complexity.

\subsection{System Cost Assessment and Life Cycle Assessment}

Model predictions from Section 6.3 point to a yearly value of SEK 25 million for case 3, with a $30{ }^{\circ} \mathrm{C}$ return water temperature. The associated cost for reaching that potential must be considered unknown in this study, where a concrete technical implementation is not stated.

With an unknown construction cost, it is obvious that it becomes hard to promote investments. However, as a hedge against higher fuel costs, the active management of heat customers could be an interesting option to increase network efficiency.

It must also be stated that there is a fundamental contradiction between a free fuel (waste incineration) and investments in efficiency improvements. 
A life cycle assessment (LCA) would be beneficial in terms of assessing the impact of these proposed new low-grade heat customers in the $\mathrm{DH}$ network. This is important for the evaluation of the proposed action, but remains outside the scope of this case study. It is important to note that there is a considerable difference in environmental impact between, for example, the reuse of radiators, adjustment of working points for valves, or installation of newly produced heating substations. With the active management of heat customers, both LCA and DHS efficiency can be included in future network development.

\subsection{DHS Development}

Looking at Linköping Municipality in 2050, with an efficient energy system that mitigates the problem of GHG emissions in an effective manner, it seems unlikely that the existing DHS will not be a part of that system. However, the authors also believe that it is unlikely that the supply and return temperatures in the DH network will remain at today's levels, when the benefits of lower temperatures are clear and technologies are available.

The assessment and evaluation of GHG emissions is crucial for understanding and interpreting how different technologies contribute to an increase or decrease in GHG emissions. A system approach gives a wider view, but also adds numerical uncertainties and increases the number of assumptions. Given that the effect of GHG emissions is a global issue, this leads us to the conclusion that the system approach is favourable.

A less detailed approach and focus on the trends and the wider system perspective show us that some observations can be made. DH is a well-established technology, and the need for heating will — with high degree of certainty-remain, even in a future low energy society, in 2050. With a system control perspective, it is possible to improve the situation for the CHP plant with existing technology. Lower return water temperature is beneficial for DHS efficiency, and the function is continuous regarding temperature. The continuous function means that an experimental introduction of low-grade heat customers can be initiated and then evaluated in an iterative process.

With the results from this case study, we propose that an interesting next move for DHS with $\mathrm{CHP}$ would be to introduce low-grade heat customers on the DH return water pipes, to achieve better system control and higher system efficiency.

During 2016, TvAB commissioned another waste incineration plant with a production capacity of $83 \mathrm{MW}$ and an electrical efficiency of $22.5 \%$. In practice, this means that the economic benefits of lower return temperature are greatly reduced for TVAB. However, considering electricity market connections and fuel market connections, the potential for GHG emission reduction, with the actions proposed in this paper, still remains.

\section{Conclusions}

The active management of customers in a DHS can lower return water temperatures faster and in the long run lead to better controlled return water temperatures. Active management is defined as an adjustment of a domestic heating system in order to improve DHS efficiency without affecting the heating service for the individual building.

In this study, the effects of introducing active management within a local DHS in Linköping, Sweden, have been analysed.

The conclusions from the study are the following:

- Possible efficiency gains of around $7 \%$, corresponding to $103 \mathrm{GWh}$ heat

- $\mathrm{GHG}$ emission reduction of $4-20 \%$

- Reduced system cost by SEK 25 million per year

The authors believe that the examined system shows results that are generalizable to other Swedish DHSs, given the high degree of technical similarity between these systems. However, 
individual differences between DHSs regarding fuel mixture and electrical efficiency for turbines must be acknowledged.

Author Contributions: All the parts of the manuscript were discussed among the two authors. T.R. was the main author and wrote all the parts.

Funding: This research received no external funding.

Acknowledgments: The work has been carried out under the auspices of Fjärrsyn (district heating and cooling research programme) and the Swedish District Heating Association. We are grateful to the people at Tekniska verken $\mathrm{AB}$ who gave us measurements and data, especially Joakim Holm, who supplied a great deal of valuable information. We also wish to thank our supporting research group, namely: Lina La Fleur, student, Linköping University; Stefan Blomquist, student, Linköping University; Tina Lidberg, student, University of Gävle (HiG); Mattias Gustafsson, student, University of Gävle; and Rasmus Lund, University of Copenhagen.

Conflicts of Interest: The authors declare no conflict of interest.

\section{References}

1. Moriarty, P.; Honnery, D. What is the global potential for renewable energy? Renew. Sustain. Energy Rev. 2012, 16, 244-252. [CrossRef]

2. Haberl, H.; Erb, K.H.; Krausmann, F.; Bondeau, A.; Lauk, C.; Müller, C.; Plutzar, C.; Steinberger, J.K. Global bioenergy potentials from agricultural land in 2050: Sensitivity to climate change, diets and yields. Biomass Bioenergy 2011, 35, 4753-4769. [CrossRef] [PubMed]

3. de Castro, C.; Mediavilla, M.; Miguel, L.J.; Frechoso, F. Global solar electric potential: A review of their technical and sustainable limits. Renew. Sustain. Energy Rev. 2013, 28, 824-835. [CrossRef]

4. Hoes, O.A.C.; Meijer, L.J.J; van der Ent, R.J.; van de Giesen, N.C. Systematic high-resolution assessment of global hydropower potential. PLoS ONE 2017. [CrossRef] [PubMed]

5. Energimyndigheten. Energiläget 2015. Available online: http://www.energimyndigheten.se (accessed on 4 May 2018).

6. Lund, H.; Werner, S.; Wiltshire, R.; Svendsen, S.; Thorsen, J.E.; Hvelplund, F.; Mathiesenf, B.V. 4th Generation District Heating (4GDH): Integrating smart thermal grids into future sustainable energy systems. Energy 2014, 68, 1-11. [CrossRef]

7. Dagilis, V.; Vaitkus, L.; Balčius, A.; Gudzinskas, J.; Lukoševičiu, V.S. Low Grade Heat Recovery System For Woodfuel Cogeneration Plant Using Water Vapour Regeneration. Thermal Sci. 2018, 22, 2667-2677. [CrossRef]

8. Ziviani, D.; Suman, A.; Lecompte, S.; de Paepe, M.; van den Broek, M.; Spina, P.R.; Pinelli, M.; Venturini, M.; Beyene, A. Comparison of a Single-screw and a Scroll Expander under Part-load Conditions for Low-grade Heat Recovery ORC Systems. Energy Procedia 2014, 61, 117-120. [CrossRef]

9. Lundström, L.; Wallin, F. Heat demand profiles of energy conservation measures in buildings and their impact on a district heating system. Appl. Energy 2016, 161, 290-299. [CrossRef]

10. Harrestrup, M.; Svendsen, S. Changes in heat load profile of typical Danish multi-storey buildings when energy-renovated and supplied with low-temperature district heating. Int. J. Sustain. Energy 2015, 34, 232-247. [CrossRef]

11. SvenskFjärrvärme. 2016. Available online: http://www.svenskfjarrvarme.se/Statistik--Pris/Fjarrvarme/ Leveranser/ (accessed on 4 June 2018).

12. Zhang, L.; Gudmundsson, O.; Thorsen, J.; Li, H.; Li, X.; Svendsen, S. Method for reducing excess heat supply experienced in typical Chinese district heating systems by achieving hydraulic balance and improving indoor air temperature control at the building level. Energy 2016, 107, 431-442. [CrossRef]

13. Tunzi, M.; Skaarup, D.; Østergaard; Svendsen, S.; Boukhanouf, R.; Cooper, E. Method to investigate and plan the application of low temperature district heating to existing hydraulic radiator systems in existing buildings. Energy 2016, 113, 413-421. [CrossRef]

14. Yang, X.; Li, H.; Svendsen, S. Decentralized substations for low-temperature district heating with no Legionella risk, and low return temperatures. Energy 2016, 110, 65-74. [CrossRef]

15. Hoes, P.; Hensen, J.L.M. The potential of lightweight low-energy houses with hybrid adaptable thermal storage: Comparing the performance of promising concepts. Energy Build. 2016, 110, 79-93. [CrossRef]

16. Churchman, C.W. The Systems Approach; A Delta book; Dell Publishing Co.: New York, NY, USA, 1968. 
17. Kensby, J.; Trüschel, A.; Dalenbäck, J.-O. Potential of residential buildings as thermal energy storage in district heating systems - Results from a pilot test. Appl. Energy 2015, 137, 773-781. [CrossRef]

18. Fredrik Wernstedt, C.J. SvenskFjärrvärme 2009. Demostrationsprojekt Inom Effekt Och Laststyrning. 2009. Available online: http://www.fukt.bsnet.se/ \{\}uncle/papers/effektstyrning.pdf (accessed on 15 May 2019).

19. Henning, D. Optimisation of Local and National Energy Systems: Development and Use of the MODEST Model; Linköping Studies in Science and Technology: Linköping, Sweden, 1999.

20. Lidberg, T.; Olofsson, T.; Trygg, L. System impact of energy efficient building refurbishment within a district heated region. Energy 2016, 106, 45-53. [CrossRef]

21. Gebremedhin, A. Introducing District Heating in a Norwegian town - Potential for reduced Local and Global Emissions. Appl. Energy 2012, 95, 300-304. [CrossRef]

22. Gode, J.M.F.; Hagberg, L.; Palm, D. Värmeforsk 2011. Miljöfaktaboken 2011. Estimated emission factors for fuels, electricity, heat and transport in Sweden. 2011. Available online: https://energiforskmedia.blob.core. windows.net/media/17907/miljoefaktaboken-2011-vaermeforskrapport-1183.pdf (accessed on 15 May 2019).

23. Judl, J.; Koskela, S.; Korpela, T.; Karvosenoja, N.; Häyrinen, A.; Rantsi, J. Net environmental impacts of low-share wood pellet co-combustion in an existing coal-fired $\mathrm{CHP}$ (combined heat and power) production in Helsinki, Finland. Energy 2014, 77, 844-851. [CrossRef]

24. Sahu, S.G.; Chakraborty, N.; Sarkar, P. Coal-biomass co-combustion: An overview. Renew. Sustain. Energy Rev. 2014, 39, 575-586. [CrossRef]

25. Olkkonen, V.; Syri, S. Spatial and temporal variations of marginal electricity generation: The case of the Finnish, Nordic, and European energy systems up to 2030. J. Clean. Prod. 2016, 126, 515-525. [CrossRef]

26. Olsson, A.; Grönkvist, S.; Lind, M.; Yan, J. The elephant in the room-A comparative study of uncertainties in carbon offsets. Environ. Sci. Policy 2016, 56, 32-38. [CrossRef]

(C) 2019 by the authors. Licensee MDPI, Basel, Switzerland. This article is an open access article distributed under the terms and conditions of the Creative Commons Attribution (CC BY) license (http://creativecommons.org/licenses/by/4.0/). 
PAPER 



\title{
Article
}

\section{System Perspective on Biogas Use for Transport and Electricity Production}

\author{
Tommy Rosén * and Louise Ödlund \\ Division of Energy Systems, Linköping University, SE-581 83 Linköping, Sweden; louise.odlund@liu.se \\ * Correspondence: tommy.rosen@liu.se
}

Received: 26 September 2019; Accepted: 29 October 2019; Published: 31 October 2019

\begin{abstract}
Linköping municipality has managed biogas driven buses in the regional transport system since 1997 and all buses in the municipality have run on biogas since 2015. Biogas is a renewable fuel and by replacing fossil fuels it can help to lower net $\mathrm{CO} 2$ emissions. However, Internal Combustion Engines (ICE) in buses still have a rather low efficiency, in the range of $15-30 \%$. If the combustion of biogas instead takes place in a combined cycle gas turbine (CCGT) efficiency could be higher and heat losses reduced. This could be a feasible solution if the transport system instead used electric buses charged with electricity generated by the CCGT. This article has a top-down perspective on the regional transport system and the regional district heating system (DHS) in Linköping municipality. Two alternative systems are compared regarding $\mathrm{CO} 2$ emissions, electricity production and component efficiencies. The first system that is studied is in operation today and uses locally produced biogas in the ICE buses. In parallel the combined heat and power (CHP) system delivers electricity and heat to households in the region. The second system that is studied is a system with electric buses and a CHP system that uses biogas in the CCGT to deliver electricity and heat to the regional power grid and DHS. The study shows that emissions would be reduced if biogas use is changed from use in ICE buses to use in the CCGT in the CHP-DHS. Improved biogas use could lower CO2-eq emissions by 2.4 million $\mathrm{kg}$ annually by using a better fuel-energy pathway.
\end{abstract}

Keywords: District heating; system perspective; electric buses; biogas; smart energy systems

\section{Introduction}

Biogas is an energy carrier that is produced by anaerobic digestion of organic material, often various kinds of food waste. Biogas can be used in several different ways to replace fossil fuels and hence reduce the emission of greenhouse gases (GHG). The reduction in GHG emissions compared to fossil fuels is estimated to be between $67 \%$ and $148 \%$, these reduction values include system expansion consequences such as changed land use and fertilizer substitution (organic fertilizer can be a residue from biogas production) [1]. In 2016, biogas production in Sweden amounted to 2 TWh [2], which corresponds to $0.3 \%$ of the total energy used in Sweden that year [3]. The most common use of biogas in 2016 was as vehicle fuel at $1145 \mathrm{GWh}$ and the second most common use was for heating at $400 \mathrm{GWh}$ [2]. In a modelling assessment of cost-effective biogas utilization, Börjesson et al. [4] conclude that only about $10-16 \%$ of the technical biogas potential will be utilized without subsidies. However, biogas utilization of about $90 \%$ is predicted with subsidies of EUR 40-60/MWh.

At the end of 2017, there were 55,117 gas vehicles in Sweden, of which 2533 were buses, 854 other heavy vehicles and the rest were cars [5]. When gas vehicles were first introduced, almost all the gas came from fossil natural gas. Since then there has been a steady trend whereby biogas has increased its share and in 2017 it accounted for $86 \%$ of the gas fuels in Sweden [5]. Fallde et al. [6] describe the biogas bus development in Linköping municipality during 1976-2015, a transition from a small niche to a new socio-technical regime with all city buses powered by biogas. 
Large truck companies such as Scania and Volvo are constantly trying to improve the gas engine but it is still not as efficient as the diesel engine, although the difference is now just a few percent [5]. Engine development will continue but the laws of thermodynamics also set an absolute upper limit to all heat-based engines. Heat losses through the cooling system, the exhaust pipe and the engine block will continue to be a large part of the energy flow from gas and diesel engines. A useful energy service derived from these heat losses is hard to envision.

After real-world testing of electric buses in eight Swedish municipalities in 2014-2015, Borén et al. [7] concluded that the tested buses had low energy use and low external noise levels. The average energy use in the tests was between 0.86 and $1.02 \mathrm{kWh} / \mathrm{km}$ and passengers and drivers gave positive feedback about the electric buses [7]. At the beginning of 2017, Sweden had 41 electric buses in commercial traffic [8] and by June 2019 that figure had risen to 172 [9]. With low energy use, low external noise and no exhaust pipe emissions, a rapid increase in electric buses in commercial traffic is a probable scenario once the technology becomes more mature. Since 2016, the Swedish Government has paid a $20 \%$ subsidy for the purchase of electric buses in order to support low emission vehicles [10]. In a lifecycle cost assessment Lajunen et al. [11] found that electric buses still have not reached competitive levels regarding cost but the authors also concluded that electric buses have the potential to significantly reduce carbon dioxide emissions, by up to $75 \%$.

A technological change from biogas ICE buses to electric buses implies more than just a fuel change. Figure 1 illustrates the more complex energy flow that must be considered if biogas is used in a CHP system and transport is carried out with electric buses.

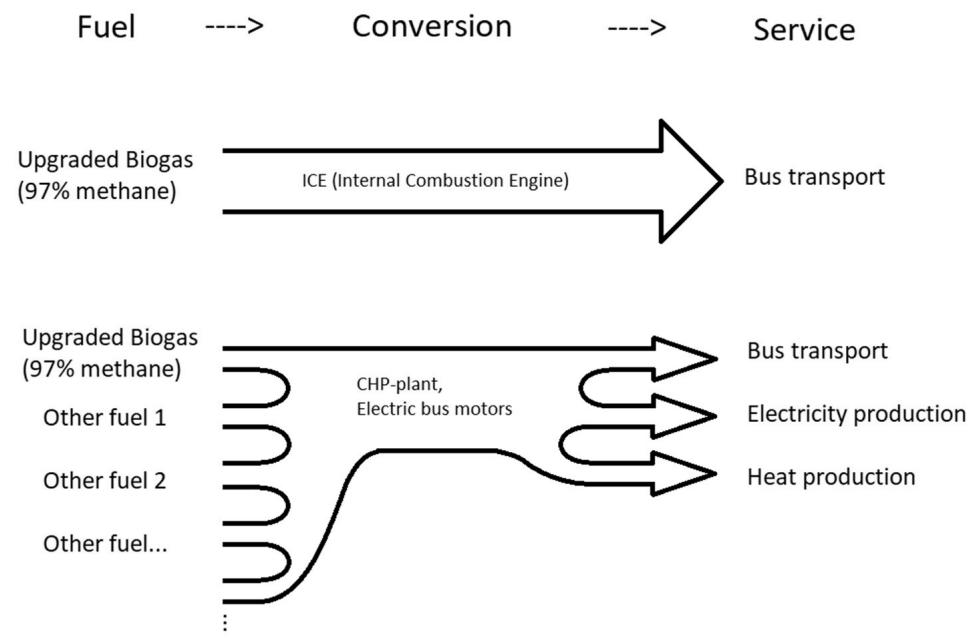

Figure 1. Schematic illustration of alternative energy flows. At the top, the energy flow for a biogas bus with internal combustion engine (ICE). At the bottom, the more complex energy flow when biogas is used in a combined heat and power (CHP) system and transport is carried out with electric buses.

Alternative uses of the produced biogas must be included in the analysis to accurately evaluate the energy system performance. In the worst case, there are no alternative uses for the produced biogas and hence the biogas will be burnt in a gas flare without creating a useful energy service. In 2016, biogas burnt in gas flares was the third most common use for biogas, corresponding to $9 \%$ of the biogas produced; this was partly due to a lack of biogas customers [2]. Hedegaard et al. [12] examined biomass use and consequences of constrained biomass availability, they concluded that technology pathways involving heat and power production and/or biogas, natural gas or electricity for transport are advantageous. 
In a Swedish context, a probable alternative use for biogas is as fuel in a CHP plant in a DHS. During 2013, the most common energy carrier for heating and hot water was district heating, at $47 \mathrm{TWh}$ [3]. DH is available in most Swedish cities but the fuel mix for each system varies considerably. The introduction of biogas in a DHS would therefore have a different impact depending on which fuels are being replaced. Some DHSs only deliver industrial waste heat to their heat customers and in those cases the introduction of biogas would not create a beneficial energy service. However, in other cases, replacing a fuel mix containing fossil fuels, it would be beneficial.

The technical solution to enable biogas use in a DHS can be implemented in several different ways. The biogas could be burnt in a heat only boiler, in a boiler connected to a steam turbine or in a CCGT (Combined Cycle Gas Turbine). The most energy efficient solution is to use a CCGT, which has the highest electrical efficiency of the three alternatives. However, CCGT is the most expensive hardware and is therefore not always a feasible option. Börjesson et al. [13] examined the cost of oil use reduction in the Swedish transport sector and concluded that biomass gasification pathways show high potential for low cost oil reduction. Use of CCGTs is central in those pathways if electric vehicles are prioritized before vehicles with ICEs.

It is crucial to consider alternative fuels, conversion efficiencies and the alternative production for the produced services. There is also a practical need to set boundaries for the analytical study. In this study the three categories: bus transport, electricity production and heat production are considered to be final products.

The aim of this study is to examine and compare two alternatives for biogas use in Linköping municipality. The first alternative that is examined is in operation today. In this system, the locally produced biogas is used as fuel in the ICE biogas buses. In parallel, the CHP system delivers electricity and heat to households in the region. The second alternative that is studied is a system with electric buses and a CHP system that uses biogas in a CCGT to deliver electricity and heat to the regional power grid and DHS. In this study CCGT is assumed to be fuelled with upgraded biogas ( $97 \%$ methane) that is, the same fuel quality as the buses use today. A whole year analysis has been conducted to summarize the accumulated system impact.

\section{Methodology}

This study used the optimization software MODEST (Model for Optimization of Dynamic Energy Systems with Time-dependent components and boundary conditions) (version-August 2015, Linköping, Sweden). The combined system and the separate transport system and DHS system were represented in the model by four different kinds of nodes: fuel nodes, conversion nodes (boilers, turbines, buses and flue gas condensers), demand nodes (heat load and transport demand) and waste nodes (electricity production and heat losses). The power plants were described in terms of efficiencies, maximum capacity and fuel type. The heat load profile was taken from measurements from 2015. The MODEST model is described in detail by Henning [14]. In recent years, several authors have used MODEST to analyse DHS, for example Lidberg et al. [15], Gebremedhin [16] and Blomqvist et al. [17]. MODEST is a top-down tool that can be used to represent the largest flows in an energy system. Figure 2 illustrates the workflow used in this study.

Two models based on power plant data, bus transport data and measurements were created. The models were optimized to cover the yearly heat load and transport demand at the lowest cost. The optimization result shows which power plants are used for each time step in the model, which in turn gives used fuels and the amount of electricity produced.

After creating and optimizing the parallel models, their results were compared and evaluated regarding fuel consumption and GHG emissions. 


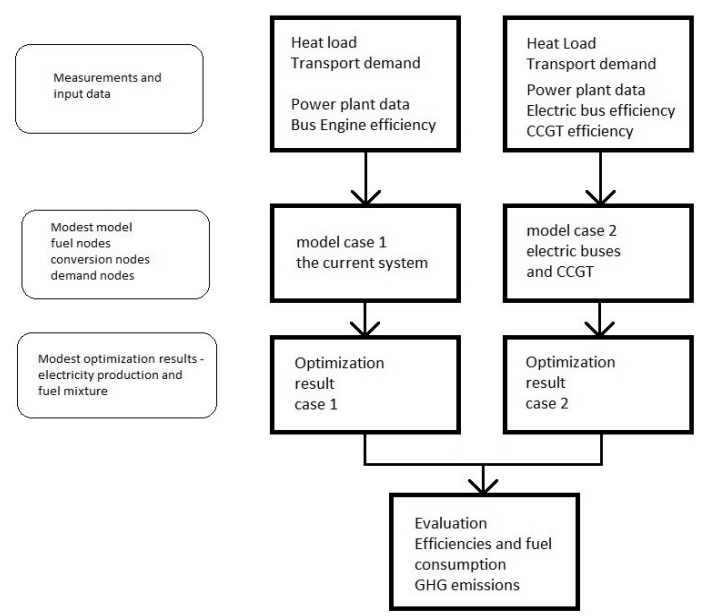

Figure 2. Schematic illustration of the workflow for the study. Horizontal lines show borders for the MODEST model.

\section{Methodological Difficulties and Boundaries}

This method is a top-down method, which means that the study starts at the top, in this case a regional energy system and then moves down in finer and finer detail. At a certain degree of system detail, one needs to stop but there is no distinct way to choose this level. In the time domain, this study starts with year, then moves to months, weeks and days and then stops. In the physical domain, this study starts with the CHP-DHS and the regional transport system in a municipality, then moves to the supply side, power plants, power plant components, fuels, buses, bus engines and then stops. It is the opinion of the authors that more detail in this model would not be beneficial for the calculations but would rather add uncertainties. There are many details in the physical domain that are omitted, in some cases by choice and in some cases by necessity. The top-down method used here is to be considered as a strategic tool to compare and evaluate possible technological pathways, not a tool to give an exact forecast of future system emissions or energy flows.

\section{Case Study}

Linköping is a municipality with about 150,000 inhabitants situated in the southeast of Sweden. Fallde et al. [6] describe how in the late 1980s LITA, the municipally owned public transport company, began to investigate a fuel change, from diesel to biogas. After a test period between 1992 and 1994, a gradual change from diesel buses to biogas was initiated. Linköping municipality has managed biogas driven buses in the regional transport system ever since, with all the buses in the municipality running on biogas from 2015. There are 65 city buses and in 2017 they delivered 5.3 million $\mathrm{km}$ of transport service. The fuel consumption was $0.6 \mathrm{Nm}^{3} / \mathrm{km}$, corresponding to $32 \mathrm{GWh}$ annually [18]. The biogas is locally produced and the annual production exceeds the consumption of the bus fleet. During 2017, production stood at 10.7 million $\mathrm{Nm}^{3}$ of upgraded biogas, corresponding to 104 GWh [19]. There is not a natural gas grid in this region where the produced gas can be injected. However, the biogas production site is situated in proximity to the city's CHP plants, which could use this biogas.

Tekniska verken $\mathrm{AB}$ is the regional power company and has a yearly production of $1500 \mathrm{GWh}$ heat and $260 \mathrm{GWh}$ electricity at two production sites. In the urban area, DH is the dominant way of supplying heat to multi-family buildings, small houses and commercial buildings. The base load in the DHS is covered by waste incineration at CHP plants. With increasing load, other CHP plants are starting to burn other fuels such as wood, rubber, coal and oil. Heat only boilers are used to cover peak loads. The fuel merit order is waste, wood, coal/rubber, oil. 
The optimization objective was to minimize the annual system cost while satisfying the given heat load demand and the transport demand. Fuel costs were fixed during the examined year and were mainly set to force the model optimization algorithm to choose plants in the correct merit order. Details of the model are shown in Tables 1-5 and Figures 3 and 4.

Table 1. Description of studied cases.

\begin{tabular}{ll}
\hline Case & Description \\
\hline Case 1 & $\begin{array}{l}\text { Model of the current system. The local transport service provided by } 65 \text { biogas driven } \\
\text { buses. CHP and DHS provide power and heat to the region. }\end{array}$ \\
Case 2 & $\begin{array}{l}\text { Model of an integrated system. Biogas is used in CCGT, which integrated in the CHP } \\
\text { and DHS. The local transport service is provided by electric buses. }\end{array}$ \\
\hline
\end{tabular}

Table 2. Modelled production units in Linköping's CHP system. Source: TvAB.

\begin{tabular}{lllll}
\hline Power Plant & $\begin{array}{l}\text { Maximum } \\
\text { Output } \\
\text { (MW) }\end{array}$ & Fuel & $\begin{array}{l}\text { Flue Gas } \\
\text { Condenser } \\
\text { Efficiency (\% of } \\
\text { Boiler Power) }\end{array}$ & $\begin{array}{l}\text { Turbine Efficiency } \\
\text { (Electricity } \\
\text { Production/Input } \\
\text { Heat) }\end{array}$ \\
\hline KV 50 & 72 & Waste incineration & $15-40$ & $0.10-0.15$ \\
KV 61 & 66 & Waste incineration & $0-22$ & $0.17-0.27$ \\
KV 81 & 83 & Waste incineration & $0-22$ & $0.17-0.27$ \\
CCGT & 150 & (Oil or Gas) + Waste & FGC not available & 0.33 \\
KV 1-wood & 60 & Wood & $20-40$ & $0.18-0.26$ \\
KV 1-coal & 60 & Coal/rubber & FGC not available & $0.18-0.26$ \\
KV 1-oil & 120 & Oil & FGC not available & $0.18-0.26$ \\
$\begin{array}{l}\text { Heat only boilers } \\
\text { (several distributed in }\end{array}$ & 240 & Oil & FGC not available & No turbine \\
DH network) & & & & \\
\hline
\end{tabular}

Table 3. Bus data in the model.

\begin{tabular}{|c|c|c|c|c|}
\hline Bus Type & $\begin{array}{l}\text { Transport } \\
\text { Intensity }\end{array}$ & Fuel & Heating and $\mathrm{AC}$ & Engine Efficiency \\
\hline Biogas ICE & $\begin{array}{l}605 \mathrm{~km} \text { bus } \\
\text { transport/hour }\end{array}$ & $\begin{array}{l}\text { Upgraded biogas } \\
\text { (97\% methane) }\end{array}$ & $\begin{array}{l}\text { Included in annual } \\
\text { fuel use. }\end{array}$ & $0.6 \mathrm{Nm}^{3}$ biogas $/ \mathrm{km}$ \\
\hline Electric & $\begin{array}{l}605 \mathrm{~km} \text { bus } \\
\text { transport/hour }\end{array}$ & $\begin{array}{l}\text { Electricity from } \\
\text { regional network }\end{array}$ & $\begin{array}{l}\text { Time dependent } \\
\text { (see Section } 4.1 \text { ) }\end{array}$ & $1.4 \mathrm{kWh} / \mathrm{km}$ \\
\hline
\end{tabular}

Table 4. Time division in the model.

\begin{tabular}{|c|c|}
\hline Period & Time Resolution \\
\hline January-April (first 10 days in monthly duration diagram) & Average heat load for $48 \mathrm{~h}$ period \\
\hline January-April (remaining days in monthly duration diagram) & Average heat load for $96 \mathrm{~h}$ period \\
\hline May-August & Average heat load for one week \\
\hline September-December (first 10 days in monthly duration diagram) & Average heat load for $48 \mathrm{~h}$ period \\
\hline $\begin{array}{l}\text { September-December (remaining days in monthly } \\
\text { duration diagram) }\end{array}$ & Average heat load for $96 \mathrm{~h}$ period \\
\hline
\end{tabular}

Table 5. Fuel prices in Model.

\begin{tabular}{ll}
\hline Fuel & Price in Model \\
\hline Waste & 0 SEK/MWh \\
Wood & 70 SEK/MWh \\
Coal/Rubber & 180 SEK/MWh \\
Oil CHP & 320 SEK/MWh \\
Oil-Heat only boiler & 600 SEK/MWh \\
\hline
\end{tabular}




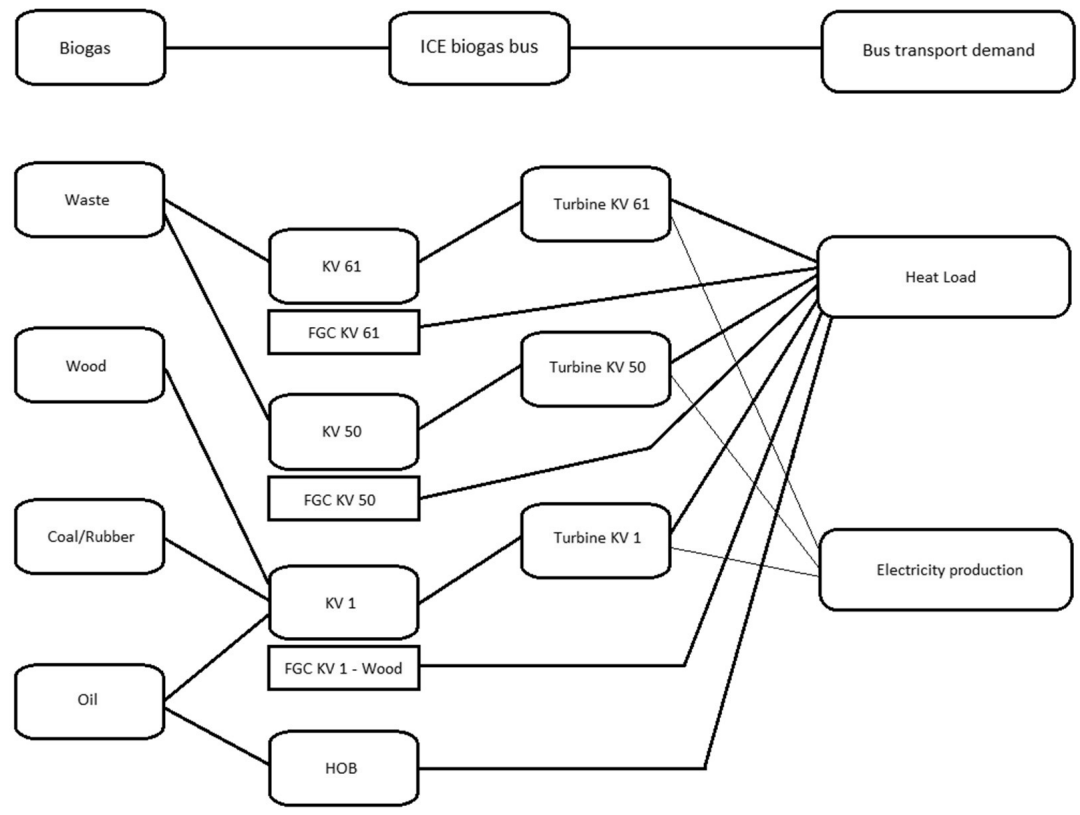

Figure 3. Illustration of nodes and flows in the Case 1 model.

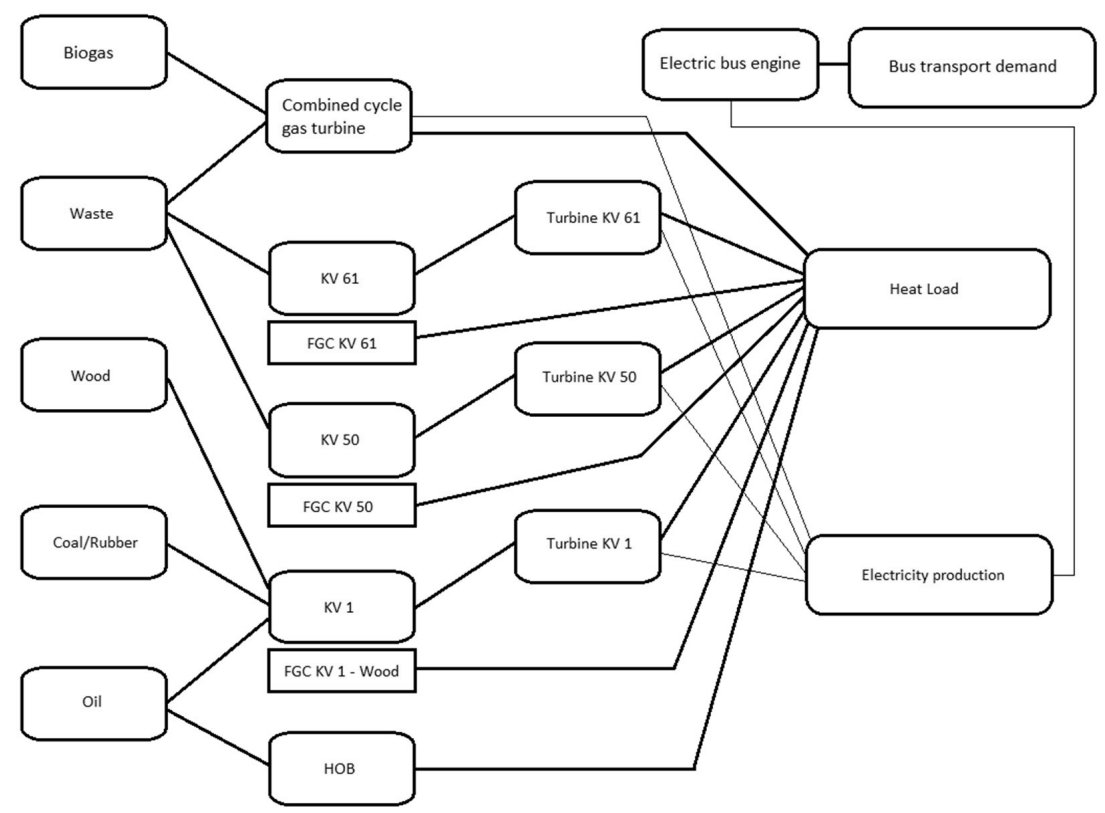

Figure 4. Illustration of nodes and flows in the Case 2 model. 
In the model the bus traffic is evenly distributed during the year. The smallest time step in the model is 2 days, which means that the transport demand node needs fuel for $48 \mathrm{~h} \times 605 \mathrm{~km} / \mathrm{h}=$ $29,040 \mathrm{~km}$ to cover that period. Time periods used in the model are presented in Table 4.

The heat load was modelled with the monthly duration diagram in Figure 5. The shortest time step used was $48 \mathrm{~h}$. All fast transients (less than $48 \mathrm{~h}$ ) are handled with the power plant heat accumulator, so the $48 \mathrm{~h}$ time step is reasonable. It is also important to note that too short a time step, for example, an hour, will create false power peaks in the model that do not exist in the real CHP plant; these power peaks are handled by the accumulator.

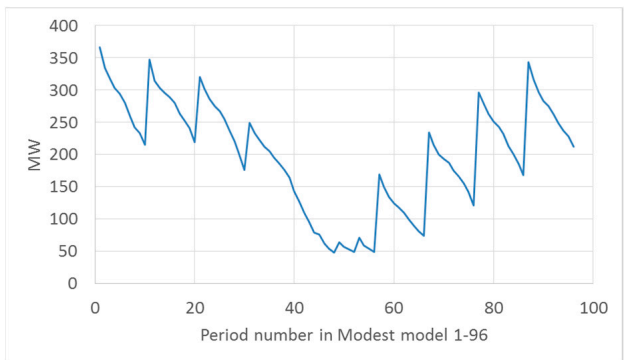

Figure 5. Heat load in the model, presented with monthly duration diagram, i.e., days sorted by heat load in each month. Days with higher heat loads are modelled in greater detail, see Table 4.

\subsection{Electric Bus Engine Efficiency}

The electric bus engine efficiency for the future system in Case 2 is unknown. However, there are electric buses in operation today and a calculation of electricity use based on existing buses is possible. The electric bus fleet in Case 2 is assumed to be of equal size to Case 1, that is 65 buses: 53 units of $18 \mathrm{~m}$ buses and 12 units of $12 \mathrm{~m}$ buses. The average energy use in the test ranged between 0.86 and $1.02 \mathrm{kWh} / \mathrm{km}$ in [7] for $12 \mathrm{~m}$ buses. In this case study, energy use is assumed to be $1 \mathrm{kWh} / \mathrm{km}$ for $12 \mathrm{~m}$ buses and $1.5 \mathrm{kWh} / \mathrm{km}$ for $18 \mathrm{~m}$ buses. With a linear calculation, energy use for the entire bus fleet becomes $1.4 \mathrm{kWh} / \mathrm{km}$. This energy use is consistent with other sources, see for example [20-22].

\subsection{Bus Heating and Air-Conditioning in the Model}

The introduction of an alternative drive train, without ICE, also affects the heating and air-conditioning for the bus. The required energy for heating and air-conditioning must be provided by the onboard energy system, instead of utilizing excess heat from the combustion. During cold days heating can be a considerable part of the total energy use for an electric bus. Borén et al. [7] measured the energy use for heating as $0.67 \mathrm{kWh} / \mathrm{km}$ in January. That measurement was done in a region with a similar climate to Linköping municipality.

In the MODEST model used in this case study, heating and AC were assumed to have an energy demand corresponding to values in Figure 6. Temperatures are average values in the region derived from SMHI [23]. Heating was assumed to be generated by an onboard heat-pump with COP 3.0. This assumption is in accordance with Göhlich et al. [24]. 


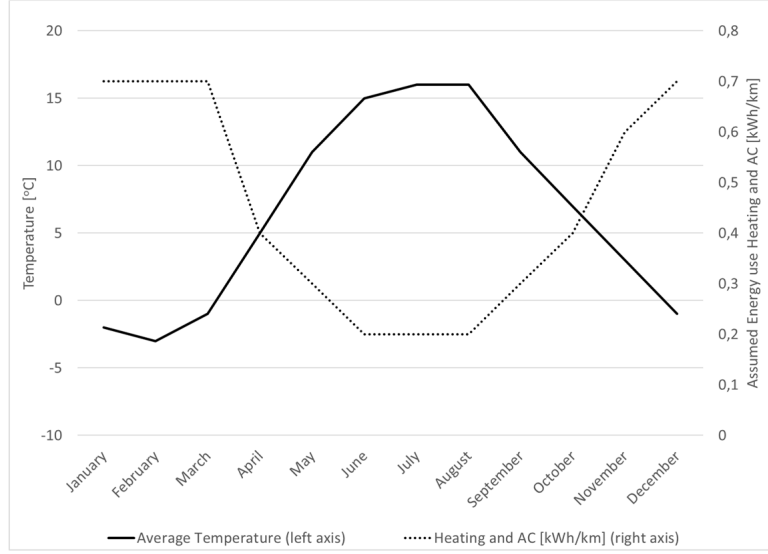

Figure 6. Temperature and assumed energy use for heating and AC for electric buses.

\subsection{Emissions in the Model}

The emission values in Table 6 are derived from The Environmental Fact Book [25]. Emissions for electricity use are calculated as average $\mathrm{CO}_{2}$-eq in the Nordic region. If excess electricity is produced by the examined system, then $131.2 \mathrm{~kg} \mathrm{CO}$-eq/MWh is subtracted from the system's local emissions.

Table 6. Emissions of greenhouse gas (GHG) $\mathrm{CO}_{2}$-eq for each fuel, The Environmental Fact Book [25].

\begin{tabular}{ll}
\hline Fuel & Emissions $\mathbf{~ k g ~ C O}$-eq/MWh \\
\hline Wood & 14 \\
Oil & 288 \\
Coal/rubber & 360 \\
Waste & 136 \\
Biogas & 39.6 \\
Electricity use & $131.2 *$ \\
\hline
\end{tabular}

* Emissions for electricity use in the Nordic region, source: IVL—Swedish Environmental Research Institute [26].

\subsection{CCGT Operation}

Linköping municipality's CHP-DHS has one CCGT unit. It is a $150 \mathrm{MW}$ unit running on $75 \mathrm{MW}$ of gas or oil and $75 \mathrm{MW}$ of waste incineration, where the steam part of the turbine uses waste as fuel. When comparing annual biogas production and the power of this CCGT unit, it is clear that this unit is oversized. However, the amount of biogas used by the buses today corresponds to running this unit at full power approximately $8 \mathrm{~h}$ every week and that is a feasible operation time. Using all locally produced biogas in the CCGT turbine would correspond to $26 \mathrm{~h}$ of full power every week. Detailed CCGT operation is not included in this study but there are several options available to handle the difference in biogas fuel access and CCGT power. Turbine retrofit is one option and dual fuel use another (burning both oil and biogas).

\section{Model Results}

This section presents the model results. The full model results for each case consist of a $38 \times 96$ matrix with all energy flows between different nodes in the model for each time step. The results presented here are selected results to illustrate the most important differences between the studied cases. 


\subsection{Efficiencies and Fuel Consumption}

A comparison of biogas use in the two studied systems is not easy. The change from Case 1 to Case 2 is not just a bus engine change; it is also a change in the delivered service from the biogas use. In Case 2 the biogas use is involved in a more complex energy flow, as illustrated in Figures 7 and 8. In Case 2 the biogas use affects waste incineration, DH heat production, electricity production and fuel supply to cover the bus transport demand. The services produced by the biogas use are a bus transport service, a heating service and an electricity production service. The biogas use in Case 2 is also directly integrated with a waste incineration fuel-energy flow.

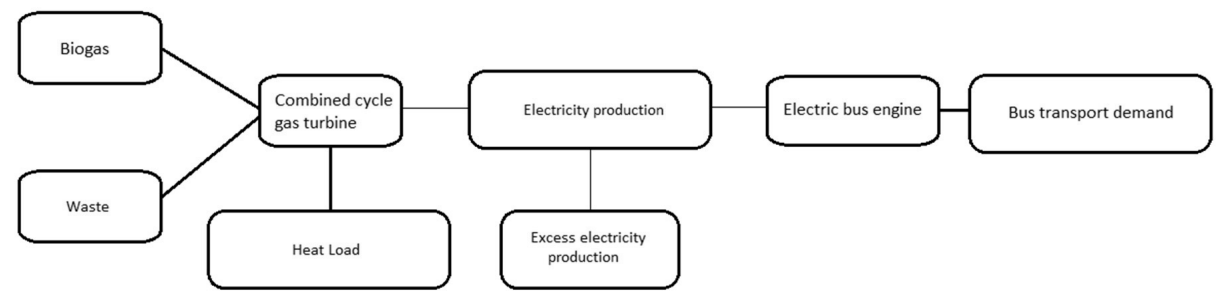

Figure 7. Fuel-energy pathway for the regionally produced biogas when the combined cycle gas turbine (CCGT) is used.

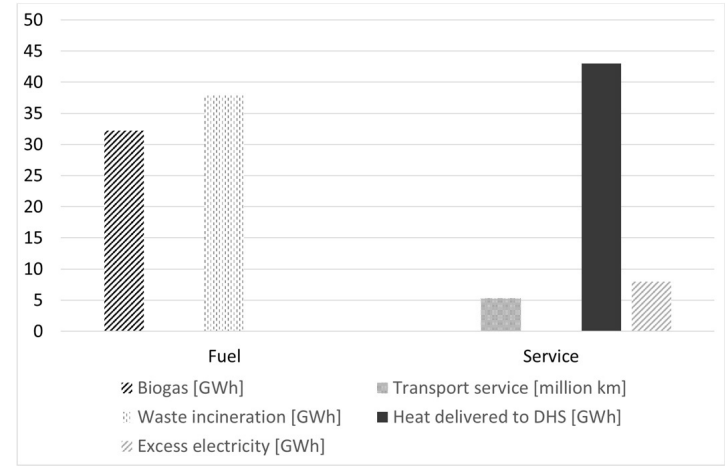

Figure 8. Fuels and services when biogas is used in the CCGT at the CHP plant.

In Case 1 the fuel-energy flow is a simple flow, where 32 GWh biogas fuel results in 5.3 million $\mathrm{km}$ bus transport service. The more complex energy system service produced in Case 2 is shown in Figure 8., with two fuels giving three services. One way to assess the value of the system integration in Case 2, compared to Case 1, is to examine the added system service. Moving from Case 1 to Case 2, $38 \mathrm{GWh}$ waste incineration is added on the fuel side and at the same time $43 \mathrm{GWh}$ of "heat delivered to DHS" is added and $8 \mathrm{GWh}$ "excess electricity production" is added. Hence, the system integration is beneficial because more services are produced with less fuel. This becomes easier to see when the entire system is studied.

\subsection{Entire System Results}

Table 7 shows the model results for the entire systems, Case 1 and Case 2. Only Case 2 uses electric buses and the CCGT, apart from that the greatest difference between the cases is in electricity production, where there is a $4 \%$ increase comparing Case 2 with Case 1 . The greater electricity production is a consequence of the use of CCGT, which has the highest electrical efficiency in the CHP system (see Table 2). Case 2 also has lower fuel use for waste, wood, coal/rubber and oil. Emissions are 
$1 \%$ lower for Case 2 , if excess electricity production is considered. In relation to the annual load for the integrated system, the differences between Case 1 and Case 2 then become small. However, in relation to the biogas flow, the differences are substantial.

Table 7. Model results, annual flows for all fuels and some selected production units.

\begin{tabular}{lll}
\hline & Case 1 & Case 2 \\
\hline Waste incineration (GWh) & 1560 & 1553 \\
Wood (GWh) & 144.7 & 142.6 \\
Coal/Rubber (GWh) & 38 & 37.1 \\
Oil (GWh) & 6.9 & 6.6 \\
Biogas (GWh) & $31.7^{*}$ & $32 . *^{*}$ \\
Total heat production (GWh) & 1459 & 1459 \\
Total electricity production (GWh) & 256.6 & 264.6 \\
CCGT electricity production (GWh) & 0 & 21.5 \\
Electric bus electricity use (GWh) & 0 & 8.0 \\
Local CO2-eq emissions (million kg) & 232.5 & 231.1 \\
CO2-eq emissions with subtraction for excess & 232.5 & 230.1 \\
electricity production (million kg) & & \\
\hline
\end{tabular}

* A small difference in biogas use is caused by the numerical method.

Figure 9. shows the differences in fuel used and electricity produced between Case 1 and Case 2. The use of wood as fuel is reduced by $2 \mathrm{GWh}$, coal/rubber is reduced by $0.9 \mathrm{GWh}$, oil is reduced by $0.3 \mathrm{GWh}$ and waste incineration is reduced by $6.4 \mathrm{GWh}$. The model also shows an $8 \mathrm{GWh}$ increase in electricity production. These system changes can also be calculated as $\mathrm{CO}_{2}$-eq emission reductions, as shown in Figure 10.

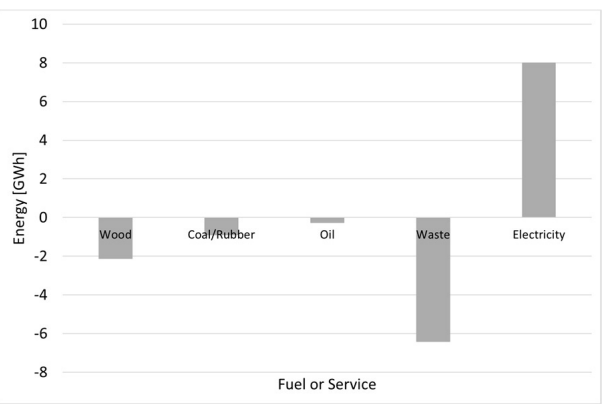

Figure 9. Differences in fuel used and electricity production between Case 1 and Case 2 .

Increased electricity production from the CHP-DHS will replace other electricity production in the electricity market. Here, the average emission value for electricity production in the Nordic region is used to calculate the effect of that replacement. With $8 \mathrm{GWh}$ increased electricity production, the $\mathrm{CO}_{2}$ reduction is greatest for this system change. Lowered waste incineration has the second largest reduction in $\mathrm{CO}_{2}$ emissions and coal/rubber combustion the third largest. The uncertainties in the top-down method should be emphasized regarding exact emission values; the interesting result is not the exact emission values but rather the overall tendency of a general fuel saving and an efficiency gain. 


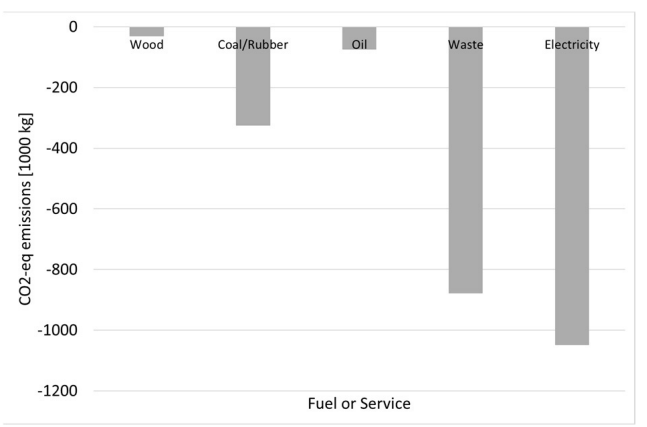

Figure 10. Differences in $\mathrm{CO}_{2}$-eq emissions $(1000 \mathrm{~kg}$ ) between Case 1 and Case 2. Emission values for each fuel from Table 5 .

\subsection{Sensitivity Study Electric Bus Efficiency}

The use of electric buses for inner city transport is a new technology and this implies greater uncertainties about efficiencies than for more established alternatives. To address this issue, the model with electric buses was also calculated with lower efficiencies for the electric bus drive train. Figure 11 shows the excess electricity production from Case 2-the integrated system with CCGT.

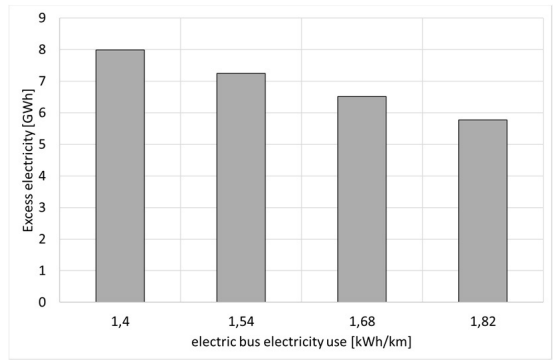

Figure 11. Excess electricity from Case 2 with different values for electric bus efficiency.

The trend is obvious and expected, lower efficiency for the electric bus will give lower excess production of electricity from the CHP-DHS. However, there is excess electricity production for the integrated system, even with an electric bus efficiency of $1.82 \mathrm{kWh} / \mathrm{km}$. The value of $1.82 \mathrm{kWh} / \mathrm{km}$ corresponds to a $30 \%$ increase in electricity use compared with the calculated value used in the model.

\section{Discussion}

The biogas fuel-energy flow is a small part of the studied regional energy system in Linköping municipality. Biogas energy use in today's ICE buses is only $2 \%$, compared to the energy use in the CHP-DHS in the municipality. This difference in size between the bus transport system and the CHP-DHS can be a problem when evaluating a system integration between these two systems. Comparing the studied cases, Case 1 and Case 2 and looking at the whole system, there is only a $1 \%$ reduction in $\mathrm{CO}_{2}$ emissions. However, from another perspective, looking at the fuel-energy pathway for the biogas, the improvement is substantial. The change from Case 1 to Case 2 eliminates 65 sources of heat loss (the buses) and redirects fuel-energy flows in more efficient pathways. The study indicates that improved biogas use could lower $\mathrm{CO}_{2}$-eq emissions by 2.4 million $\mathrm{kg}$ annually by using a better fuel-energy pathway.

There is an asymmetrical information situation regarding the two compared cases in this case study. The first case is well known and the input data for the model is derived from reliable measurements. 
Input data for the second case model has more uncertainties. Both electricity use for the electric bus engine and the electricity use for AC and heating in the buses are based on theoretical assumptions guided by literature and experiments. There is also uncertainty about CCGT efficiency for the suggested operation. However, these three uncertainties all affect the same part of the model result, the excess electricity production.

With an overall evaluation of the uncertainties regarding the differences between Case 1 and Case 2 , the following can be stated. Increased electricity production is likely. Elimination of heat losses is certain. A net reduction in fuel use is certain. However, there is less certainty about which specific fuel use (waste, wood, oil, coal/rubber) will be reduced.

This case study can to some extent be generalized to other CHP-DHSs and regional bus transport systems. A changed fuel-energy pathway for biogas can be beneficial for CHP-DHS with CCGT and the key issue is whether the change results in higher efficiencies in the fuel-energy pathway. The higher efficiency could be both a reduction in heat losses and lower losses of energy quality, that is, higher electrical efficiency. However, each specific energy system must be analysed separately in order to evaluate a change in the fuel-energy pathway for biogas.

\section{Conclusions}

Moving from Case 1 to Case 2, $38 \mathrm{GWh}$ waste incineration is added to the fuel side, along with 43 GWh of "heat delivered to DHS" and 8 GWh "excess electricity production." Hence, the system integration is beneficial because more services are produced with less fuel. The study indicates that improved biogas use could lower $\mathrm{CO}_{2}$-eq emissions by 2.4 million $\mathrm{kg}$ annually by using a better fuel-energy pathway.

Implementation of new technology is complicated and certainly not only a matter of theoretical calculations; several practical issues and economic conditions must also be addressed. However, this theoretical case study does not reject a development where biogas use is altered from combustion in bus engines to combustion in combined cycle gas turbines. On the contrary, the regional energy system perspective is in favour of such a development, because of the elimination of heat losses and the improvement to the biogas fuel-energy pathway.

Author Contributions: All the parts of the manuscript were discussed among the two authors. T.R. was the main author and wrote all the parts.

Funding: This research received no external funding.

Conflicts of Interest: One of the authors, T.R., has in his private stock portfolio stocks in two companies which manufacture buses. One company manufactures both electric and biogas driven buses, the other company only electric buses. Due to the stock portfolio, one might consider that a conflict of interest could be present in this research work. The author T.R. could have an economic benefit in the case of an increasing electric bus market. However, no data, measurements or other material in this article have been derive from any of these companies. The conclusion is therefore that the content in this article has not been affected by the private stock ownership.

\section{References}

1. Life Cycle Assessment of Biofuels in Sweden; Department of Technology and Society, Environmental and Energy Systems Studies, Lund University: Lund, Sweden, 2010.

2. Energimyndigheten. Produktion och Användning av Biogas och Rötrester år 2016; Energimyndigheten: Eskilstuna, Sweden, 2016.

3. Energimyndigheten. Energiläget; Energimyndigheten: Eskilstuna, Sweden, 2015; Available online: www. energimyndigheten.se (accessed on 1 July 2019).

4. Börjesson, M.; Ahlgren, E.O. Cost-effective biogas utilisation-A modelling assessment of gas infrastructural options in a regional energy system. Energy 2012, 48, 212-226. [CrossRef]

5. Energigas Sverige. Available online: http://www.energigas.se/fakta-om-gas/fordonsgas-och-gasbilar/ statistik-om-fordonsgas/ (accessed on 8 December 2018).

6. Fallde, M.; Eklund, M. Towards a sustainable socio-technical system of biogas for transport: The case of the city of Linköping in Sweden. J. Clean. Prod. 2015, 98, 17-28. [CrossRef] 
7. Borén, S.; Nurhadi, L.; Ny, H. Preference of Electric Buses in Public Transport: Conclusions from Real Life Testing in Eight Swedish Municipalities. Int. J. Environ. Ecol. Eng. 2016, 10, 255.

8. Powercircle.org. Available online: http://powercircle.org/nyhet/hur-manga-elbussar-finns-sverige/ (accessed on 6 December 2018).

9. Antal Elbussar i Sverige, 2019. Available online: https://www.elbilsstatistik.se/elbilsstatistik (accessed on 13 October 2018).

10. Swedish Government. Förordning (2016:836) om Elbusspremie; Swedish Government: Stockholm, Sweden, 2016.

11. Lajunen, A.; Lipman, T. Lifecycle cost assessment and carbon dioxide emissions of diesel, natural gas, hybrid electric, fuel cell hybrid and electric transit buses. Energy 2016, 106, 329-342. [CrossRef]

12. Hedegaard, K.; Thyø, K.A.; Wenzel, H. Life Cycle Assessment of an Advanced Bioethanol Technology in the Perspective of Constrained Biomass Availability. Environ. Sci. Technol. 2008, 42, 7992-7999. [CrossRef] [PubMed]

13. Börjesson, M.; Ahlgren, E.O. Modelling transport fuel pathways: Achieving cost-effective oil use reduction in passenger cars in Sweden. Technol. Forecast. Soc. Chang. 2012, 79, 801-818. [CrossRef]

14. Henning, D. Optimisation of Local and National Energy Systems: Development and Use of the MODEST Model. Ph.D. Thesis, Linköping University, Linköping, Sweden, 1999.

15. Lidberg, T.; Olofsson, T.; Trygg, L. System impact of energy efficient building refurbishment within a district heated region. Energy 2016, 106, 45-53. [CrossRef]

16. Gebremedhin, A. Introducing District Heating in a Norwegian town-Potential for reduced Local and Global Emissions. Appl. Energy 2012, 95, 300-304. [CrossRef]

17. Blomqvist, S.; Amiri, S.; Rohdin, P.; Ödlund, L. Analyzing the Performance and Control of a Hydronic Pavement System in a District Heating Network. Energies 2019, 12, 2078. [CrossRef]

18. Ostgotatrafiken, 2018. Available online: www.ostgotatrafiken.se (accessed on 18 September 2018).

19. Tekniska_verken_AB, 2018. Available online: www.tekniskaverken.se (accessed on 27 August 2018).

20. Zhou, B.; Wu, Y.; Zhou, B.; Wang, R.; Ke, W.; Zhang, S.; Hao, J. Real-world performance of battery electric buses and their life-cycle benefits with respect to energy consumption and carbon dioxide emissions. Energy 2016, 96, 603-613. [CrossRef]

21. Topal, O.; Nakir, I. Total Cost of Ownership Based Economic Analysis of Diesel, CNG and Electric Bus Concepts for the Public Transport in Istanbul City. Energies 2018, 11, 2369. [CrossRef]

22. Ma, Y.; Ke, R.Y.; Han, R.; Tang, B.J. The analysis of the battery electric vehicle's potentiality of environmental effect: A case study of Beijing from 2016 to 2020. J. Clean. Prod. 2017, 145, 395-406. [CrossRef]

23. Monthly Average Temperature in Sweden, SMHI. Available online: https://www.smhi.se/klimatdata/ meteorologi/temperatur (accessed on 3 December 2018).

24. Göhlich, D.; Ly, T.A.; Kunith, A.; Jefferies, D. Economic assessment of different air-conditioning and heating systems for electric city buses based on comprehensive energetic simulations. World Electr. Veh. J. 2015, 7 , 398-406. [CrossRef]

25. Gode, J.M.F.; Hagberg, L.; Palm, D. Miljöfaktaboken 2011: Estimated Emission Factors for Fuels, Electricity, Heat and Transport in Sweden; 2011 VÄRMEFORSK Service AB 10153 STOCKHOLM; VÄRMEFORSK: Stockholm, Sweden, 2011; ISSN 1653-1248.

26. Gode, J.M.F.; Arnell, J.; Höglund, J. Emissionsfaktorer för Nordisk Elproduktionsmix B2118; IVL Svenska Miljöinstitutet: Stockholm, Sweden, 2012.

(C) 2019 by the authors. Licensee MDPI, Basel, Switzerland. This article is an open access article distributed under the terms and conditions of the Creative Commons Attribution (CC BY) license (http://creativecommons.org/licenses/by/4.0/). 


\section{FACULTY OF SCIENCE AND ENGINEERING}

Linköping Studies in Science and Technology, Licentiate Thesis No. 1863, 2019

Department of Management and Engineering

Linköping University

SE-581 83 Linköping, Sweden

www.liu.se 